\title{
ANALYSES OF THE HYDROLOGIC PERFORMANCE OF BIORETENTION FACILITIES
}

\author{
by: \\ Seyed Amirali Alinaghian \\ MSc., Azad University, Tehran, Iran, 2015
}

\begin{abstract}
A thesis
presented to Ryerson University

in partial fulfillment of the

requirements for the degree of

Master of Applied Science

in the program of

Civil Engineering
\end{abstract}

Toronto, Ontario, Canada, 2019

(c) Seyed Amirali Alinaghian, 2019 


\section{Author's Declaration}

I hereby declare that I am the sole author of this thesis. This is a true copy of the thesis, including any required final revisions, as accepted by my examiners.

I authorize Ryerson University to lend this thesis to other institutions or individuals for the purpose of scholarly research.

I further authorize Ryerson University to produce this thesis by photocopying or by other means, in total or in part, at the request of other institutions or individuals for the purpose of scholarly research.

I understand that my thesis may be made electronically available to the public. 


\title{
Abstract
}

ANALYSES OF THE HYDROLOGIC PERFORMANCE OF BIORETENTION FACILITIES

\author{
Seyed Amirali Alinaghian \\ Master of Applied Science \\ Civil Engineering, 2019 \\ Ryerson University
}

Due to urbanization, and replacing natural pervious lands by impermeable surfaces, the patterns of rainfall-runoff are altered and thus, negatively influence natural water systems regarding both water quantity and water quality.

Bioretention as an efficient LID practice has received significant interest in the recent years. Bioretention practice due to its advantages can be considered as one of the most promising LID practices that maintains the fundamental hydrologic functions in a natural environment and can be integrated into neighborhood landscaping. The primary objective of the current study is analyzing the effects of inflow and outflow characteristics on right-of-way (roadside) bioretention facilities. Inlet and outlet flow hydrographs under several design storm conditions were examined. After the formulation of a SWMM model (node and link plus LID), numerical experiments including sensitive analysis will be designed to simulate and investigate the runoff control performance of a right-of-way bioretention facility. The effective length of the bioretention was found by FLOW3D software (finite element). The performance of the bioretention cell with the effective lengths (12 \&16m) reinvestigated and results compared to original bioretention cell. 


\section{Acknowledgments}

I would first like to express my deep gratitude and appreciation to my supervisors Dr. James Li for their precious advice, guidance and support throughout my research study. In addition, I would like to thank Dr. Darko Joksimovic for his useful comments during this research.

I acknowledge the assistance of administrative staffs and technologists in the Department of Civil Engineering at Ryerson University.

I also would like to extend my sincere thanks to all my colleagues in the Department of Civil Engineering at Ryerson University for their helpful advice and suggestions. 


\section{Dedication}

To my dearest Yasaman

For her love and support

And to my lovely son

Armin 


\section{Table of Contents}

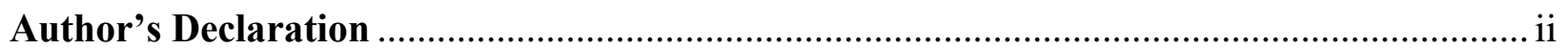

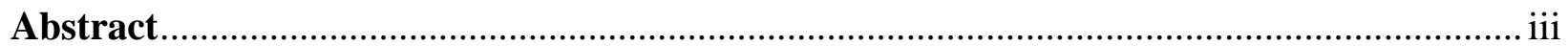

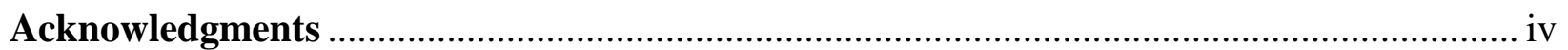

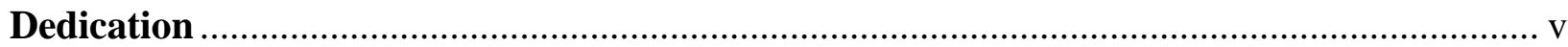

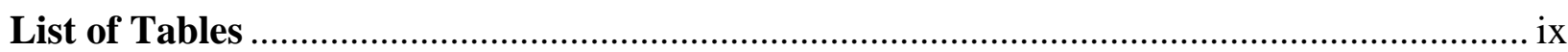

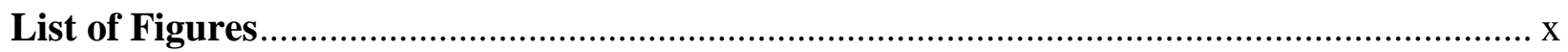

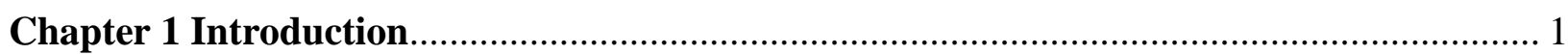

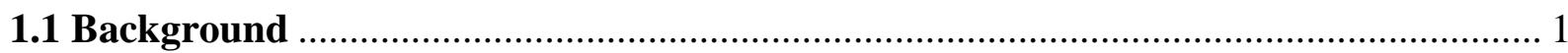

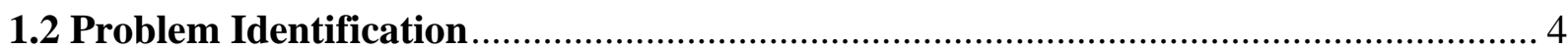

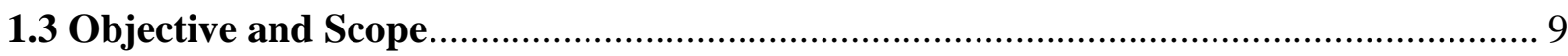

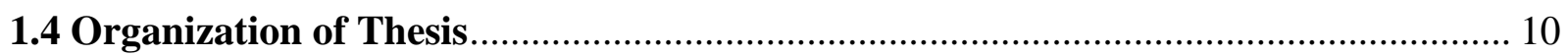

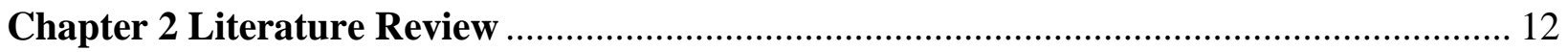

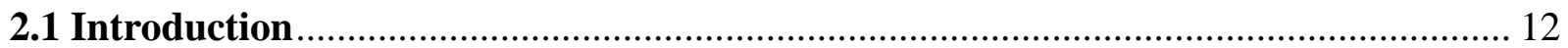

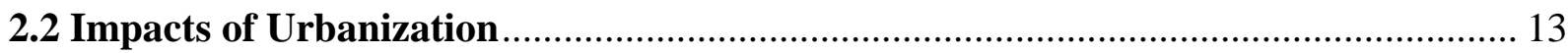

2.2.1 Stormwater Quantity Impacts ..................................................................... 13

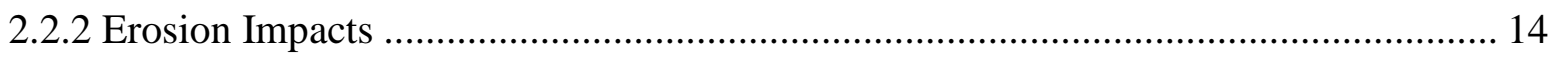

2.2.3 Stormwater Quality Impacts ........................................................................ 14

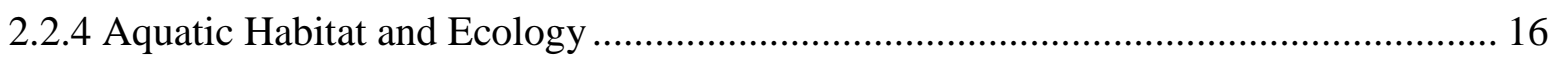

2.3 Evolution of stormwater management in Ontario ................................................... 17

2.4 Conventional and new stormwater management facilities ..................................... 18

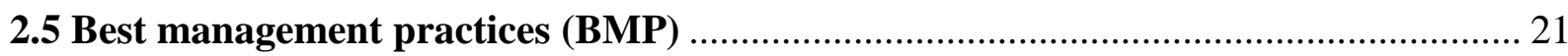

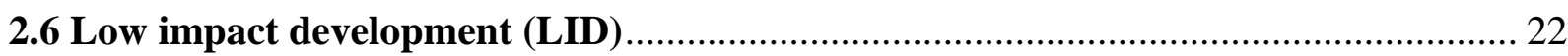

2.6.1 History of Low Impact Development in North America ....................................... 23

2.6.2 Low Impact Development in Ontario .............................................................. 24

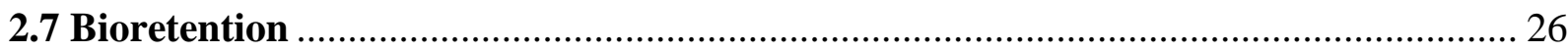

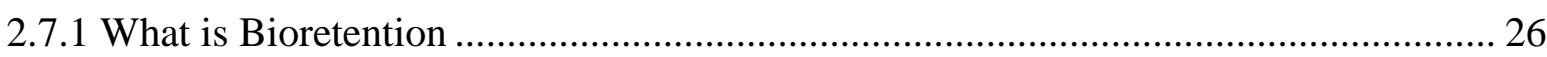

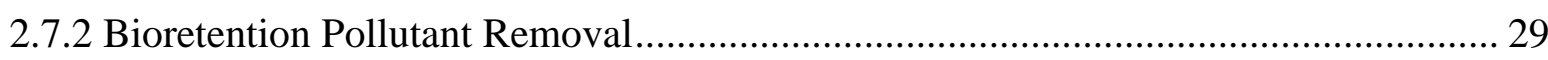

2.7.3 Bioretention Soil and its Functions ................................................................... 29

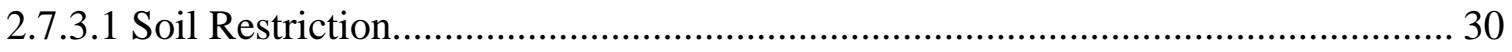

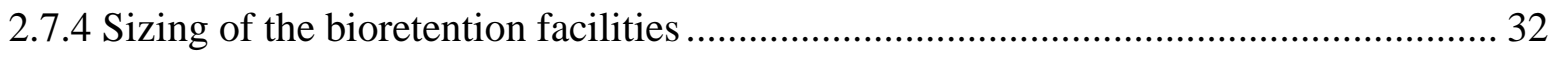

2.7.5 Performance of the bioretention facilities.............................................................. 33

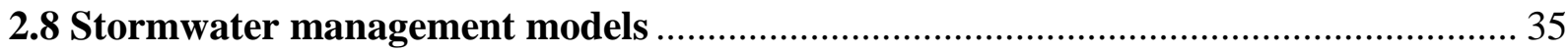

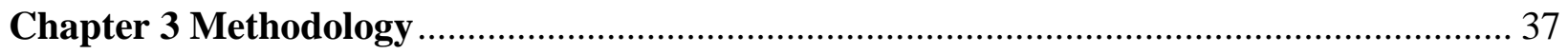




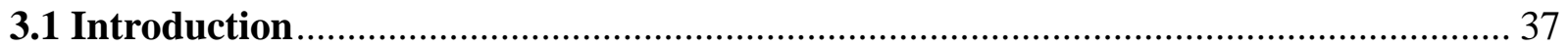

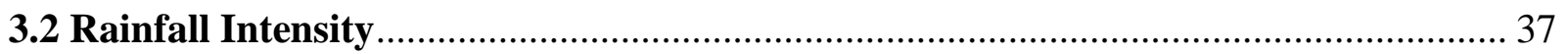

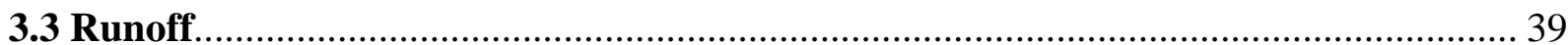

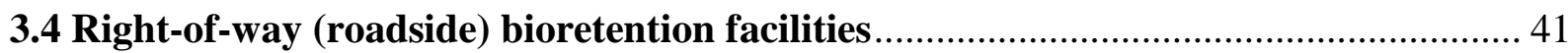

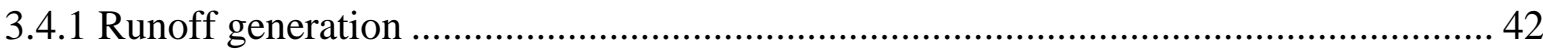

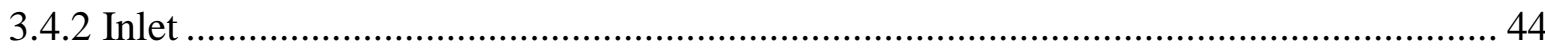

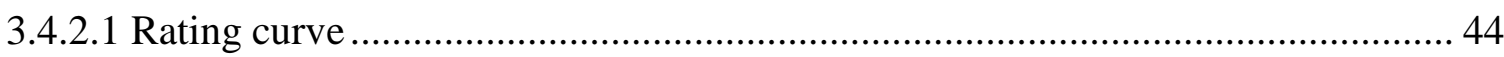

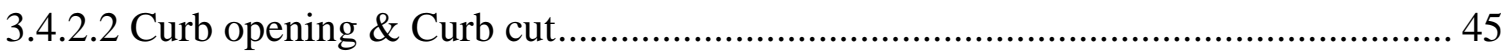

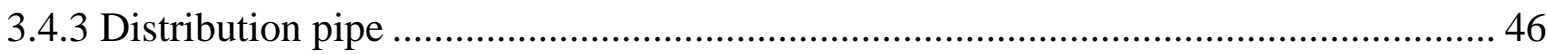

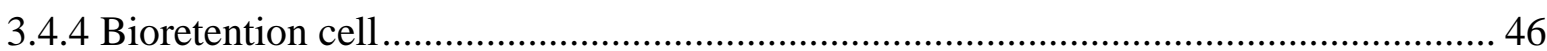

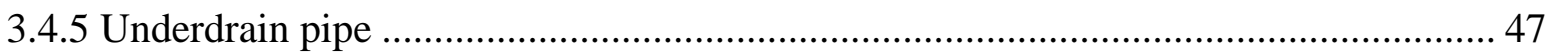

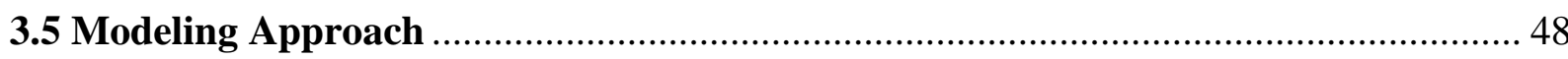

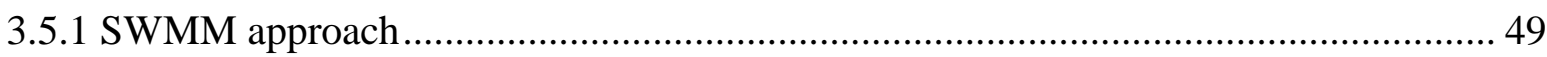

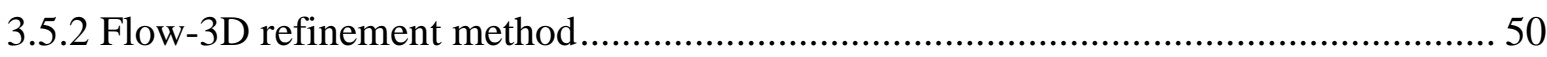

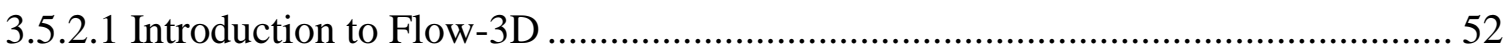

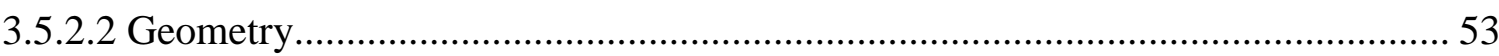

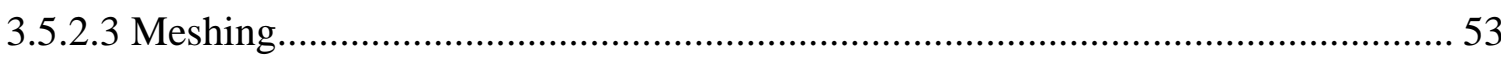

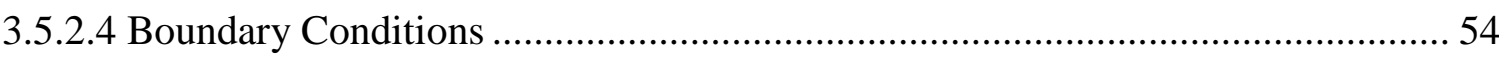

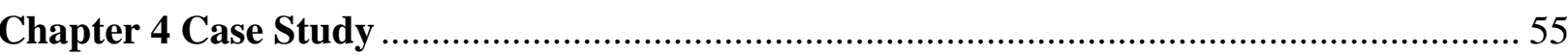

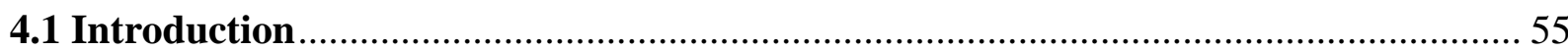

4.2 Underground Bioretention System of Sustainable Sidewalk ................................... 55

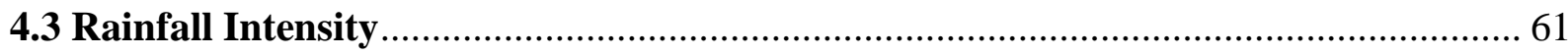

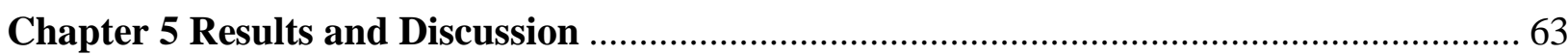

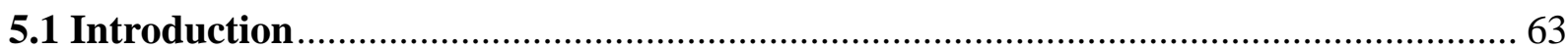

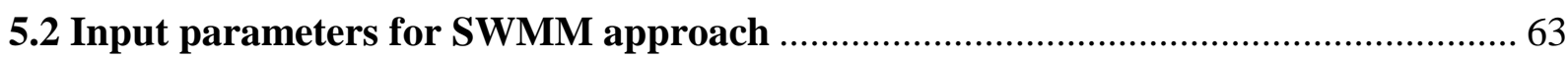

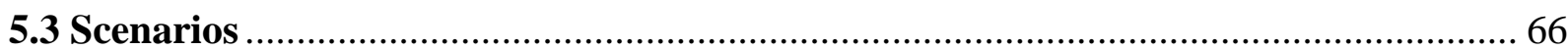

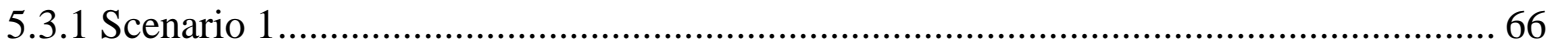

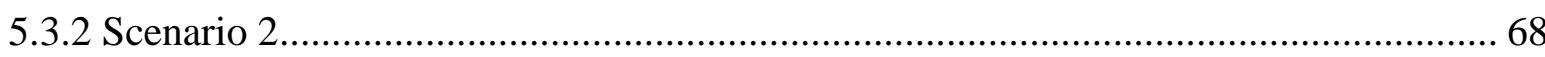

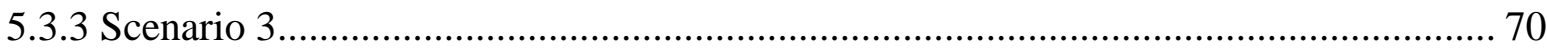

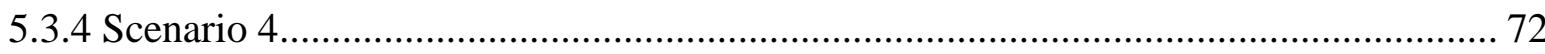

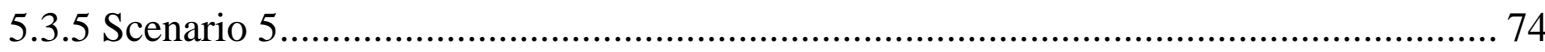

5.3.6 Scenario 6

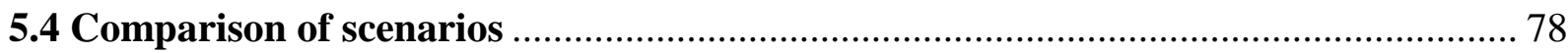

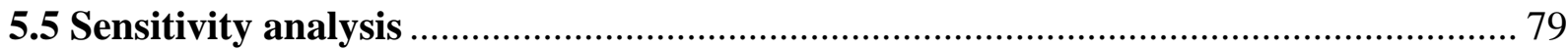

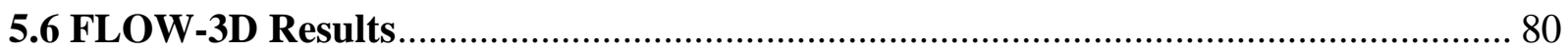




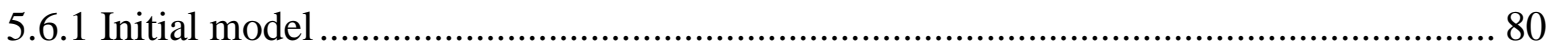

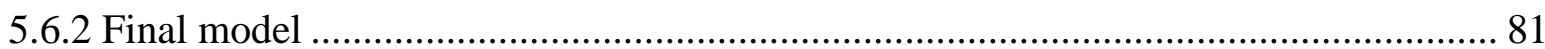

5.7 Performance of the bioretention cell with new sizing .......................................... 83

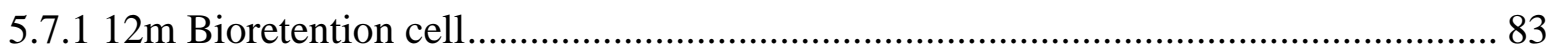

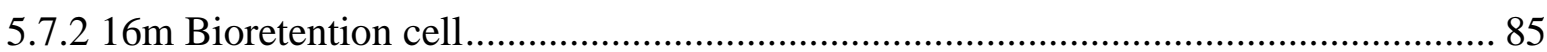

5.7.3 Comparison of $100 \%, 88 \%$ \& $67 \%$ bioretention cell ............................................. 87

5.8 Performance of the bioretention cell in continues simulation .................................. 92

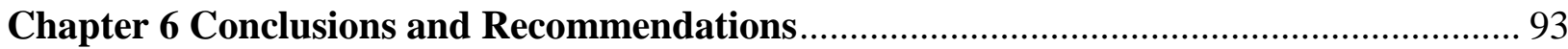

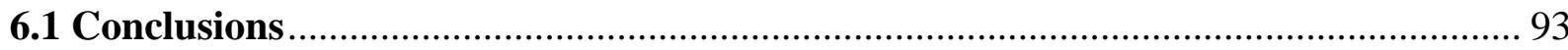

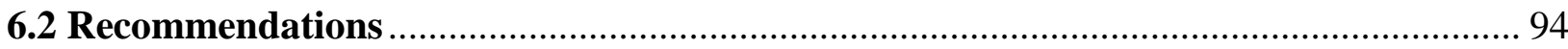

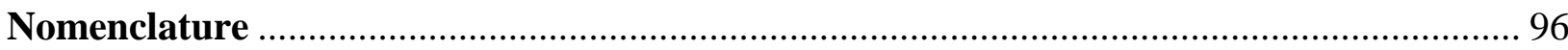

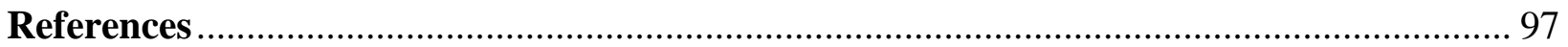




\section{List of Tables}

Table 2-1. Comparison of Urban Stormwater Runoff Concentrations with Provincial Water

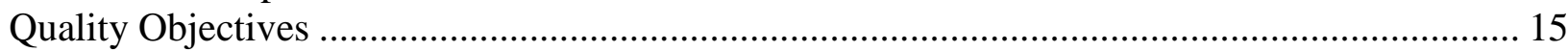

Table 2-2. Nutrient concentration and guidelines at the inlet of stormwater treatment facilities. 16

Table 2-3. List of stormwater management practices to aid practioners in selecting practices.... 20

Table 2-4. Reported Pollutant Removal Performance of Bioretention Systems ....................... 29

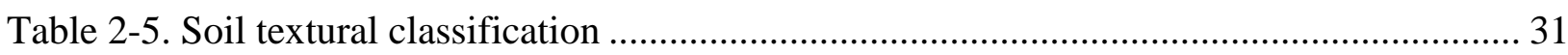

Table 2-6. Bioretention Criteria for Length and Width ......................................................... 33

Table 3-1: General runoff coefficients for the rational method ............................................... 40

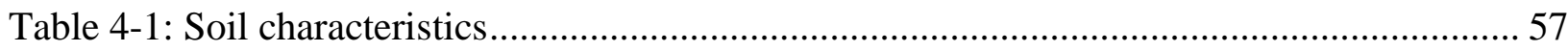

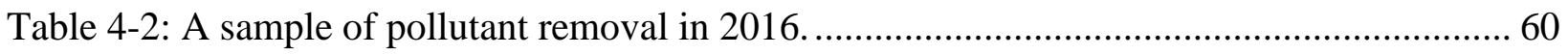

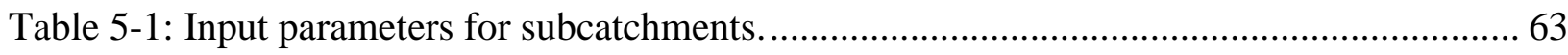

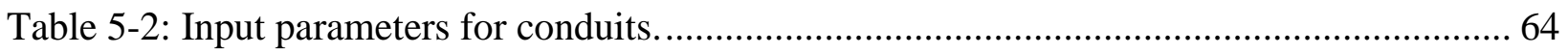

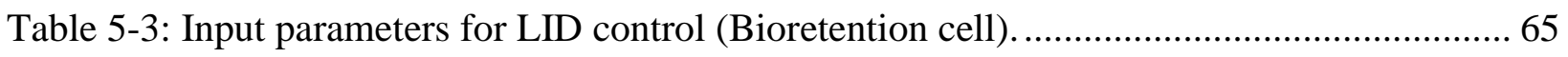

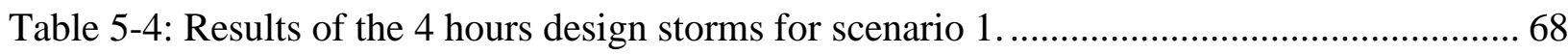

Table 5-5: Results of the 4 hours design storms for scenario 2 ........................................... 70

Table 5-6: Results of the 4 hours design storms for scenario 3............................................ 72

Table 5-7: Results of the 4 hours design storms for scenario 4 ............................................. 74

Table 5-8: Results of the 4 hours design storms for scenario 5........................................... 76

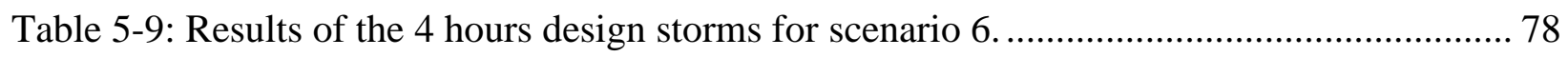

Table 5-10: Results of the 4 hours design storms for $12 \mathrm{~m}$ bioretention cell. ............................ 85

Table 5-11: Results of the 4 hours design storms for $16 \mathrm{~m}$ bioretention cell. ............................ 87

Table 5-12: Performance of bioretention cell in continues simulation..................................... 92 


\section{List of Figures}

Figure 1-1. Schematic diagram illustrating relationship between rainfall, infiltration and runoff . 5

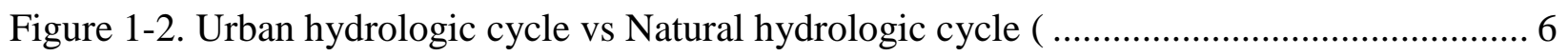

Figure 1-3. Separated sewer systems have two pipes: sanitary sewers and storm sewers............... 7

Figure 1-4. Combined sewer systems have one pipe ............................................................. 7

Figure 2-1. Population growth from 1960 to 2050 in urban \& rural areas ..................................... 12

Figure 2-2. Relationship between impervious cover and surface runoff .................................... 13

Figure 2-3. Effects of urbanization on volume and rates of surface water runoff ........................ 14

Figure 2-4. Masses of dead fish float in the Haihe River in North China's Tianjin municipality

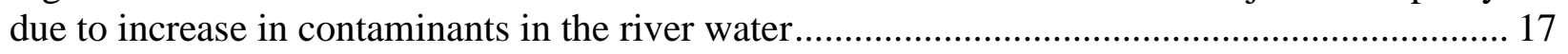

Figure 2-5: Evolution of stormwater management in Ontario from 1980 to Present .................... 18

Figure 2-6: Mitigation of adverse environmental impacts by using "treatment train" ................. 21

Figure 2-7: Sites implemented LID in Ontario ………….................................................. 26

Figure 2-8: Bioretention layers and hydrologic function of a bioretention facility ……………... 27

Figure 2-9: Different types of Bioretention in Canada \& the United States (U.S.) ....................... 28

Figure 2-10: Percent fines and hydraulic conductivity relationship ............................................. 31

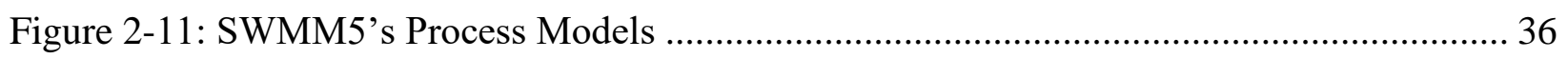

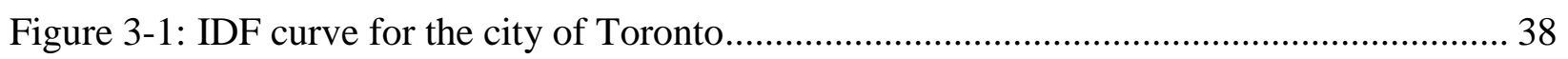

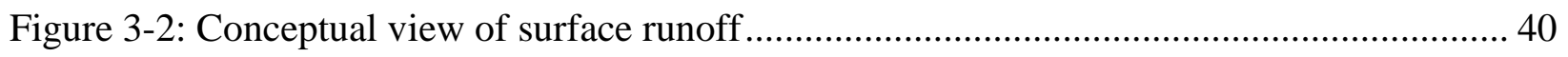

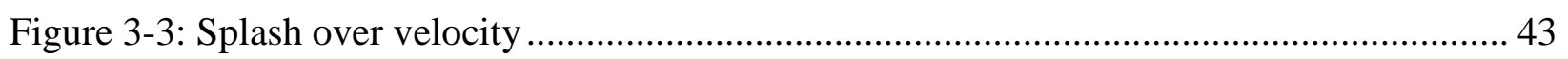

Figure 3-4: Inlet capacity curves for different catch basins........................................................ 44

Figure 3-5: OPSD 400.07 catch basin during and after the rainfall event in the City of Toronto in

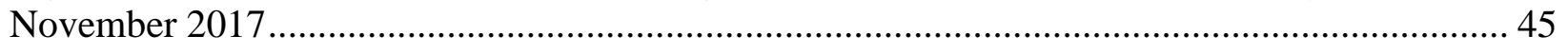

Figure 3-6: An example of perforation alignment of the perforated Pipe ................................... 46

Figure 3-7: A conceptual view of a bioretention cell and flow equations .................................... 47

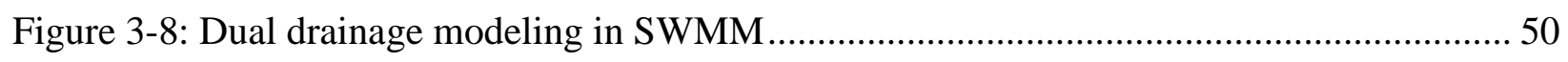

Figure 3-9: Flow pathways through the bioretention system.................................................. 50

Figure 3-10: First Scenario in Flow-3D software in $\mathrm{x}, \mathrm{z}$ direction ............................................ 51

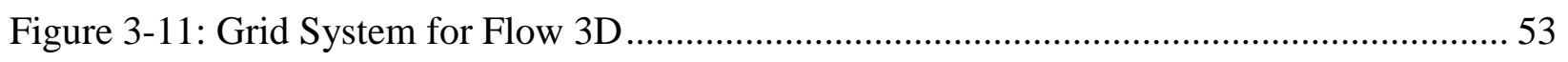

Figure 3-12: Mesh generation for the perforated pipe ............................................................ 54

Figure 4-1: Site Location of the Bioretention System at Queensway Avenue in Toronto ............ 55

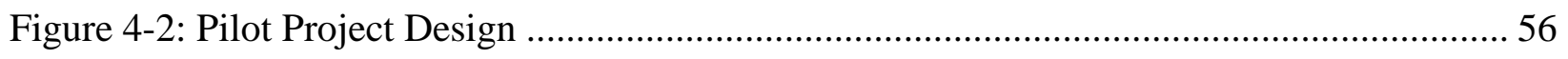

Figure 4-3, 4-4: Installation of the bioretention facility \& Upper perforated pipe for flow distribution on the top of bioretention cell and catch basin connection on the top right .............. 56

Figure 4-5: Definition Sketch of Bioretention System Cross Section ........................................ 57 
Figure 4-6, 4-7: Tree cell of underground Bioretention (www.deeproot.com), Finished parking lay-by and sidewalk on top of the bioretention facility

Figure 4-8, 4-9: The autosampler device at the Queensway Avenue, and inlet \& outlet samples that collected by the autosampler on a rainfall event 59

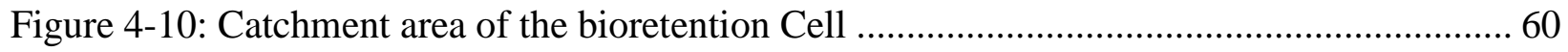

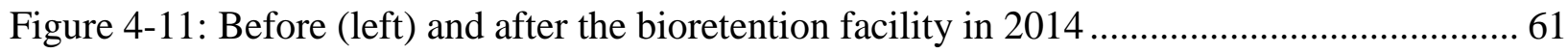

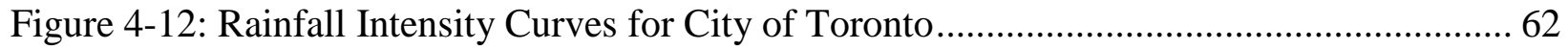

Figure 4-13: Different design storms hyetographs generated by PCSWMM........................... 62

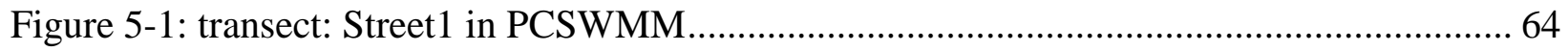

Figure 5-2: Outlet, Inlet \& bypass hydrographs for single \& twin horizontal bar/fishbone catch

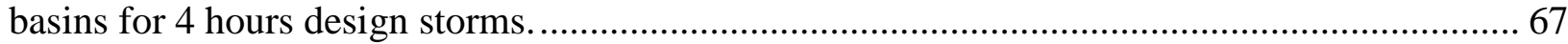

Figure 5-3: Outlet, Inlet \& bypass hydrographs for OPSD400.01 catch basin for 4 hours design storms.

Figure 5-4: Outlet, Inlet \& bypass hydrographs for single \& twin grid catch basins for 4 hours design storms.

Figure 5-5: Outlet, Inlet \& bypass hydrographs for single \& twin honeycomb catch basins for 4 hours design storms

Figure 5-6: Outlet, Inlet $\&$ bypass hydrographs for curb opening for 4 hours design storms ...... 75

Figure 5-7: Outlet, Inlet $\&$ bypass hydrographs for curb cut for 4 hours design storms ............. 77

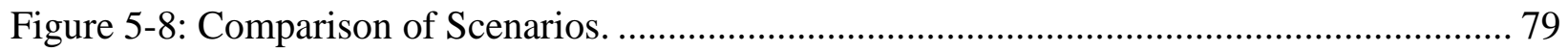

Figure 5-9: Comparison of the FLOW-3D with experimental results ...................................... 80

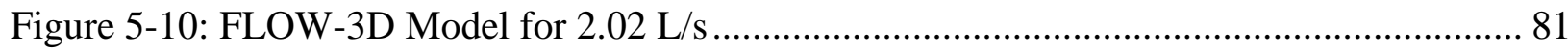

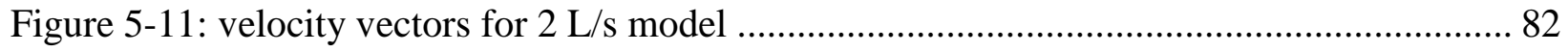

Figure 5-12: Water profiles for different flows modeled with FLOW-3D .............................. 82

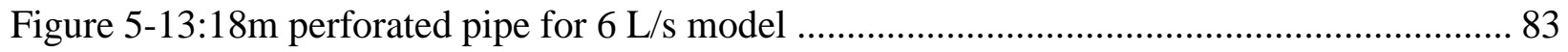

Figure 5-14: Outlet, Inlet \& bypass hydrographs for single \& twin horizontal bar/fishbone catch basins for 4 hours design storms for $12 \mathrm{~m}$ bioretention cell ............................................... 84

Figure 5-15: Outlet, Inlet \& bypass hydrographs for single \& twin horizontal bar/fishbone catch basins for 4 hours design storms for $16 \mathrm{~m}$ bioretention cell .................................................. 86

Figure 5-16,5-17,5-18: The performance of 100,88,67\% bioretention cell for different return periods

Figure 5-19,5-20,5-21,5-22,5-23: The modified inflow \& outflow hydrographs for different design storms 


\section{Chapter 1 Introduction}

\subsection{Background}

Due to urbanization, and replacing natural pervious lands with impermeable surfaces, patterns of rainfall-runoff have been altered and are negatively influencing natural water systems with regard to both water quantity and water quality. These impermeable surfaces (e.g., roofs, roads, parking lots, ...) prevent rainfall from infiltrating into the soil structure, which results in water quantity issues such as increased runoff volumes, and high peak flows. Also, with the expansion of urban areas, we are removing trees and natural habitats and transforming them into roads and buildings and commercial areas. As a result, the chances of having floods, soil erosion and water pollution have risen remarkably (Bendehali,2015). That is why we need stormwater management.

Proper stormwater management practices are needed to decrease the adverse impacts on the hydrologic cycle such as more runoff, less soil infiltration by precipitation especially in urban areas. Inappropriate stormwater management practices cause high baseflow, degradation of water quality and high chances of having floods and soil erosion. These parameters are the reasons why there has been reduced diversity of aquatic life, improper use of water resources and loss of property and human life (Ontario Ministry of Environment (MOE),2003).

Conventional stormwater management practices store water temporarily at the end of the downstream (End-of-pipe stormwater management practices) to increase the quality and decrease the volume of runoff (P.G. County,2007). To satisfy the multiple objectives of stormwater management such as maintaining the hydrologic cycle, avoiding more erosion and flooding, and protection of water quality, a combination of lot level, conveyance, and end-of-pipe stormwater management practices are usually used. Lot and conveyance controls cause the reducing size of end of pipe facilities that are used for flood and erosion control, and water quality improvement for retaining the natural hydrologic cycle. The impacts of urbanization have been controlled by end-of-pipe stormwater management practices. However, the effects of urbanization remains by applying lot level and conveyance measures according to preventative methods (Ontario Ministry of Environment (MOE),2003). 
In urban areas, poor stormwater management practices can be more harmful than many natural disasters. On July $8^{\text {th }}, 2013$, Toronto experienced a flash flood, with $10 \mathrm{~cm}$ (4") of rain falling in just two hours (Chow,2013). The property damage was over $\$ 850$ million. Also, after June 2013, in southern Alberta insurance companies paid over $\$ 1.7$ billion for property damages due to the flooding. Flood-related insurance claims have exceeded $\$ 1$ billion for the past six years across Canada (Rain Community Solutions,2015).

Water quantity and flood control are the main components of the traditional stormwater management. Recently, stormwater management has focused more on water quality aspect. So, Best Management Practices (BMPs) and Low Impact Development (LID) techniques have been established (Liu, 2016).

Methods, actions or any structural controls used to accomplish the quantity and increase the quality of stormwater runoff are parts of Stormwater Best Management Practices (BMPs) (US EPA, 1999). Depending on the requirements of the project, BMPs can be used to attain different goals. The three major objectives of the BMPs in particular LIDs are: flow control, pollutant removal, and pollutant source (US EPA, 1999).

Recently, LID technologies are receiving increased attention in relation to the management of stormwater runoff from developed sites. LID strategy is a popular technique that emphasizes onsite stormwater management in developed and developing areas with the aim of imitating the hydrologic features of pre-development situations. (Credit Valley Conservation (CVC); Toronto and Region Conservation (TRCA), 2010).

Also, low-impact development (LID) practices focus on on-site treatment and more infiltration of stormwater into natural soil. Different stormwater management methods including bio-swales, rain gardens, bioretention, green streets, and pervious pavements cover the term LID. The LID technique was first introduced in the early 1990s in Prince George's County, Maryland as a substitute for conventional stormwater controls. Many practical LID projects were built in a few communities in the Chesapeake Bay area. Also, interest in replacing conventional stormwater management practices with LID projects and case studies increased significantly across the North America (U.S. EPA 2000). 
Bioretention as an efficient LID practice has received significant interest in recent years. Due to its advantages, bioretention can be considered as one of the most promising LID practices that maintains the fundamental hydrologic functions in a natural environment and can be integrated into neighborhood landscaping.

In 1995, Schueler did comprehensive work on the importance of imperviousness. According to his work, the relationship between imperviousness and run-off is explained broadly. The runoff coefficient represents the portion of rainfall volume that is changed into storm runoff volume and ranged from zero to one. The runoff coefficient almost follows percent impervious cover excluding low elevations where soils and slope parameters become more significant. For instance, the total runoff volume for a one-acre parking lot $(\mathrm{Rv}=0.95)$ is about 16 times more than runoff volume than a predevelopment field $(\mathrm{Rv}=0.06)($ Schueler, 1995).

The US EPA did an initial and comprehensive review on LIDs in 2000. The feasibility and reliability of data on LID projects and comparing LID with conventional stormwater management practices were conducted in that literature review. Before this review, most of the previous reports mainly focused on the potential stormwater-management benefits of LIDs. They also found that LID practices could provide more cost effective and much lower (almost zero) maintenance costs than traditional stormwater practices (U.S. EPA and Low Impact Development Center 2000). One of the first studies conducted by the Center for Watershed Protection mainly focused on the economic aspects of optimal site design for many LID practices (Center for Watershed Protection 2000).

In a newly developed area, LID practices facilitate addressing environmental issues, not only in retrofit existing highly urbanized polluted areas. (US EPA, 2000). LID practices have some economical and environmental advantages. The US EPA estimated the costs of these new practices throughout the United States in 17 LID projects in 2007. They found that implementing LID practices decrease the project costs and enhance environmental performance (US EPA, 2007).

The Ontario Ministry of Environment's (MOE) principal beliefs for efficient stormwater management practices and climate Change's strategies are in using LID. The Ministry of Environmental and Climate Changes (MOECC) found out that the current stormwater management plans that had been proposed to the ministry didn't answer all the stormwater 
management issues and wouldn't preserve the natural hydrology. "Clarify the ministry's existing needs and guidance on stormwater management" and "Create a LID stormwater management guidance document" have been suggested to enhance the utilization of LIDs. (Ministry of Environment and Climate Change, 2015).

Water Sensitive Urban Design (WSUD) has been used in Australia in response to the concept of LID. WSUD is a practice that combines the management of the total water cycle into the urban development process in urban planning and design (Government of South Australia Adelaide, 2009). WSUD basically joins landscape architecture and stormwater management facilities by using a dynamic procedure for distinguishing the design opportunities (Wong, 2006).

Finally, for solving the issues associated with existing conventional development practices, LID practices can answer most of problems associated with land development and stormwater management in several urban areas. The new development, retrofit, and redevelopment are the components of LID design that address environmental issues. Vegetative cover, topography of the selected area and other land factors should be changed as little as possible in new development projects. Retrofit projects can be applied to existing sites such as buildings, roads, parking areas, site features, and stormwater management plans. Furthermore, redevelopment projects are parts of LID design. LID focuses on retrofit projects that replace conventional design strategies by using most of the surface in infrastructures that have an effective hydrologic function (Udin,2012).

\subsection{Problem Identification}

During a rainfall event, the initial water from the rainfall is caught by the leaves and stems of vegetation. The first wave of capturing is generally called interception storage. After a while, rainwater moving on the ground surface infiltrates into the soil until the rainfall intensity surpasses the infiltration capacity of the soil. After the infiltration capacity reaches maximum, most of the depressions (depression storage) are filled and then runoff will be generated. Infiltration capacity relies on many parameters such as structure, texture and soil moisture content from the previous seasons. As the rain continues, the capacity of the soil is reduced to the point that it attains the steady value or final equilibrium capacity (final infiltration rate). 


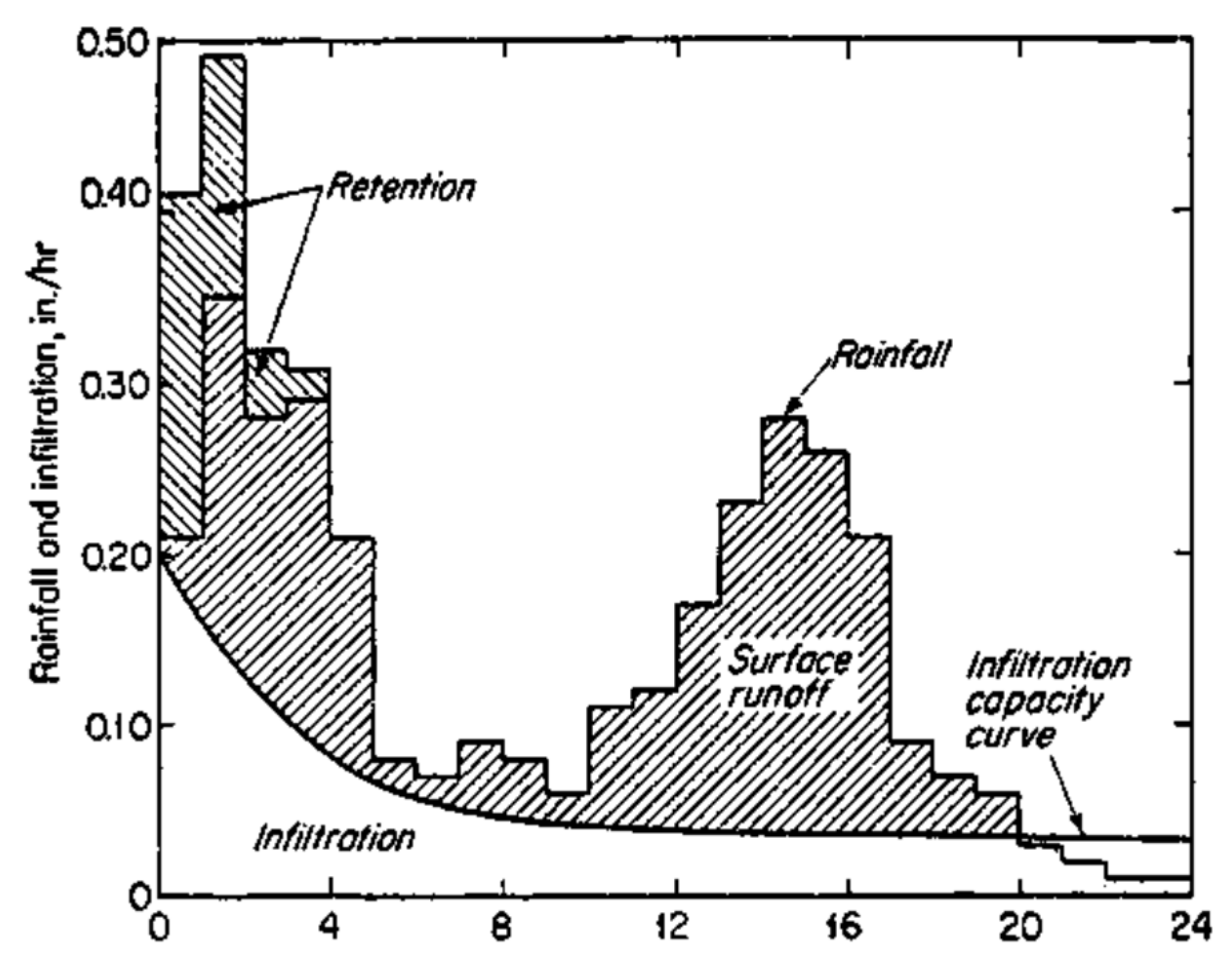

Figure 1-1. Schematic diagram illustrating relationship between rainfall, infiltration and runoff (Linsley et al. 1958).

The rainfall intensity surpasses the actual infiltration capacity of the soil in the runoff generation process during rainfall events and infiltration will cease instantly when the rainfall intensity is below the actual rate of infiltration as shown above in Figure 1-1 (FAO (1991)).

As we know, urbanization changes natural ground cover such as meadows, jungles, and floodplains. New development in the urban areas also substitutes natural surface with impervious surfaces like roads, roofs, parking lots and will reduce infiltration, evapotranspiration, water quality and increase runoff. (The Municipal Infrastructure Group Ltd.; Schollen \& Company Inc., 2011).

Figure 1-2 shows the difference between the urban hydrologic cycle and the water cycle in nature. The water balance of a natural condition usually consists of a high infiltration rate along with percolation into ground water and transpiration through vegetation (Todd, 1959). 


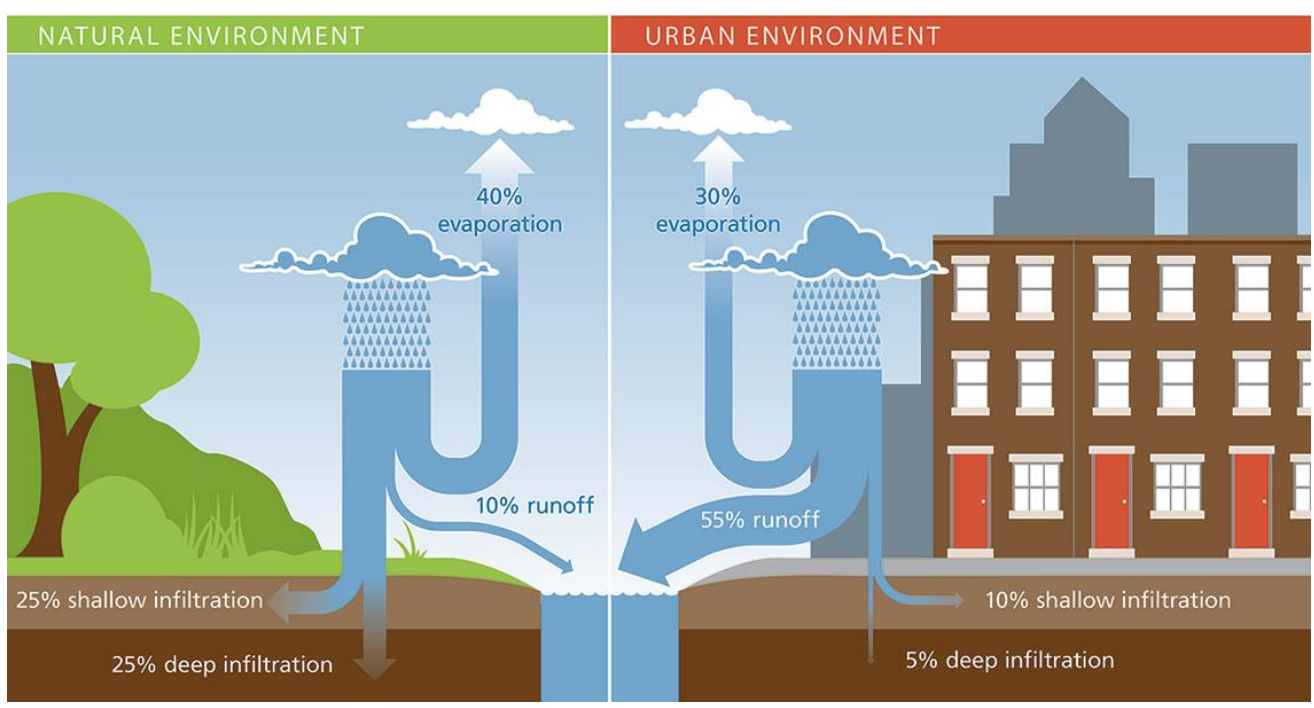

Figure 1-2. Urban hydrologic cycle vs Natural hydrologic cycle (City of Philadelphia, n.d).

Urbanization causes changes in the water balance and sometimes can eliminate some parameters. Researchers such as Landsberg (1970) had focused on urbanization around 1970. He found that increasing impervious areas can increase the speed of runoff in urban areas. In the last twenty years, research on the effect of urbanization on stormwater management has received significant interest.

To provide a better understanding of the problem, we considered the city of Toronto, Ontario, Canada as an example. In the city of Toronto, there are two types of sewer systems:

- $\quad$ Separated Sewer System (Figure 1-3).

- Combined Sewers System (Figure 1-4).

The separated sewer system has two types of sewers: 1- Sanitary sewers 2- Storm sewers

1- Sanitary Sewers: Wastewater coming from sinks, toilets, and other appliances is transferred to sanitary sewers. The wastewater from residential and commercial buildings flows to treatment plants and is treated before release into Lake Ontario.

2- Storm sewers: Storm sewers receive rainwater, stormwater, and snowmelt from different inlet configurations such as catch basins (grate inlets), curb openings \& etc. on the roadside. Without any treatment, this water goes into rivers, streams, channels, or a body of water, in this case Lake Ontario (City of Toronto,2014). 


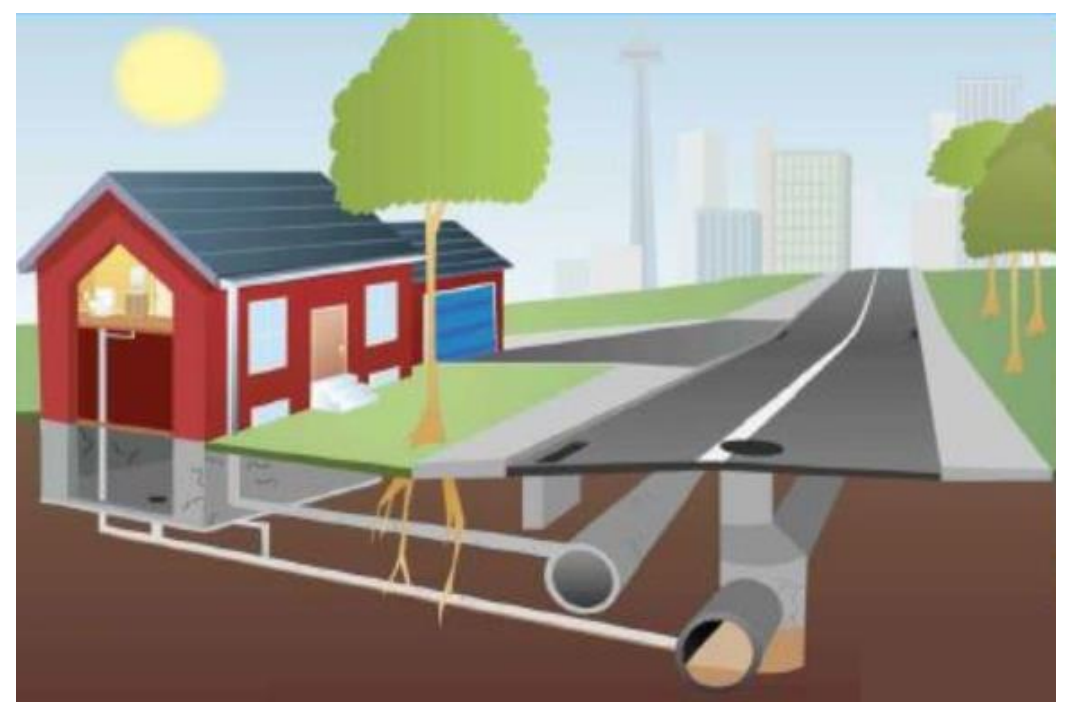

Figure 1-3. Separated sewer systems have two pipes: sanitary sewers and storm sewers (City of Toronto,2014).

Almost $23 \%$ of the combined sewers system was constructed one hundred years ago, especially in the city's older areas. In this system, one sewer (pipe) transfers both stormwater and wastewater. Full treatment applies to all fluids including rainwater, stormwater, melted snow, and sewage. The chance of overflow in a combined sewer is very high during heavy rainfall events (City of Toronto, 2014).

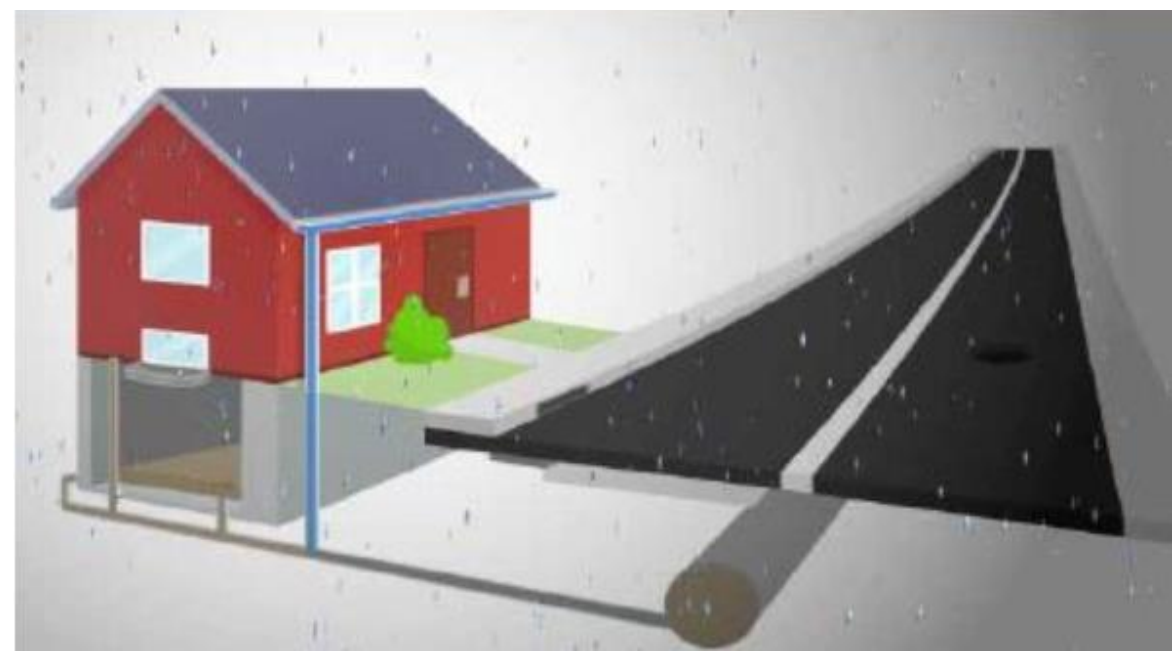

Figure 1-4. Combined sewer systems have one pipe (City of Toronto,2014).

In addition to water quantity, the combined sewer systems are the big concern particularly at the time of heavy rainfall events. Rainwater can mix with untreated sewage from combined sewer systems and increase the pollution level of streams, lakes and other water bodies. Therefore, water quality is one of the vital problems that we are still dealing with. 
Before LID practices, conventional stormwater management only focused on decreasing peak flow and runoff volume in predevelopment areas to minimize downstream flooding. This objective was usually satisfied by building detention ponds. Detention ponds are parts of dry systems that receive most of the volume of runoff and keep it and then ultimately discharge the total detained volume of runoff to receiving waters. (Abida et at, 2007). So, the detention ponds didn't really reduce the total volume of runoff, they just kept the runoff and released it- the rate of runoff changes over a period of time. New stormwater management practices started to discuss the problem of water quality by considering the danger of contamination effect of urban runoff (Udin,2012).

For the last thirty years, new technologies and techniques have been used for optimizing conventional stormwater practices. LID techniques were invented almost thirty years ago in Prince George's Country, in Maryland, United States.

The city of Toronto has suggested several new stormwater management practices or LID techniques like green roof technologies, roof leader's disconnection, rainwater harvesting, bioretention, permeable pavements etc. for efficient stormwater management in the city over the next 25 years (City of Toronto,2006). Technical specifications and the designs of these LID practices should be described clearly based on field tests of these practices in terms of suitability, performance, construction and maintenance requirements for replacing conventional stormwater practices with LIDs (Li, 2008).

The performance of LID practices, in pilot trials as a new method to effectively have stormwater management is very reasonable, but the performance in winter conditions in terms of suitability, groundwater contamination is still controversial (Dietz, 2007). Holman-Dodds et al. (2003) also stated that LID practices don't work very well in higher rainfall events.

In this research, we have used the city of Toronto's bioretention project at The Queensway Ave. in Etobicoke as the case study. This bioretention cell is different from traditional bioretention cells since it is underground- which means this cell doesn't have the surface layer. The Queensway Sustainable Sidewalk project was constructed in the fall of 2008 by Deeproot Canada consultant and the city of Toronto to analyze the performance of a right-of-way (roadside) bioretention in terms of stormwater quality and quantity. This project was funded by Toronto Water in collaboration with researchers from Ryerson University. This study mainly focuses on the 
hydraulic and hydrologic performance of urban runoff in the Queensway Sustainable Sidewalk project.

The system contains the following sections:

- Dual Catch Basin (OPSD 400.07).

- Upper corrugated perforated pipe.

- Silva Cell (engineered soil) by Deeproot Canada.

- Underdrain perforated pipe.

- Manhole and returning the stormwater to the sewer system.

Stormwater or urban runoff from the road is captured by the dual catch basin and after filling the dead storage, the runoff flows through the upper corrugated perforated pipe and infiltrates the Silva cell. After treatment, the treated water comes back to the sewer system since the system is not connected to native soil underneath the bioretention cell. Less road runoff enters the sewer system suddenly and water is kept in the soil cell and after a while drains to the sewer system. In that way, we decreased the peak flow and increased the detention time.

There are some LID manuals at the provincial level like Low Impact Development Stormwater Management Planning and Design Guide (2012) from TRCA \& CVC but the lack of federal Guides or manuals and lack of bioretention in highly urbanized areas especially in downtown Toronto motivated us to find better design recommendations that would have practical and efficient LID practices in Canada. Recently, Kaykhosravi et al. (2018) published a comprehensive review of LID models and they didn't address the inlet design control. Therefore, there's a research gap that we need to address in this research for inlet design control or different inlet configurations. Also, the hydraulics of the inlet control should be considered precisely especially in the roadside conditions. The lack of hydraulic of the inlet design control needs to be investigated and wisely address the research gap.

\subsection{Objective and Scope}

The primary objective of the current study is to analyze the effects of inflow and outflow characteristics on right-of-way (roadside) bioretention facilities. In order to attain this goal, we try to focus on the inlet and outlet flow hydrographs under several design storm conditions. We are 
modeling the whole system using the Queensway Sustainable Sidewalk project in Etobicoke as the case study and the US EPA Storm Water Management Model (SWMM) and different manuals such as the Ministry of Transportation Ontario (MTO) Drainage Management Manual (1997), Hydraulic Engineering Circular No. 22 (HEC-22) Urban Drainage Design Manual from the US Department of Transportation Federal Highway Administration (USFHWA) (2013), the City of Toronto Wet Weather Flow Management Guidelines (2006) for investigating different inlet configurations in terms of water quantity (urban runoff) before and after bioretention cell. The research focuses on the following investigations and different scenarios:

- Evaluating the performance of this LID practice (bioretention cell) in terms of stormwater runoff volume and peak flow reduction with dual drainage modeling (major or a section of the street) \& minor or sewer system);

- Using different inlet configurations such as different catch basins (OPSD 400.01, horizontal bar/fishbone, grid catch basins etc ), curb cut, curb opening,

- Using several design storm conditions like a 2,5,10,25,100- year design storm and even continues simulation.

- Using two different soils: sandy loam and loamy sand.

- Modeling of the upper perforated pipe with the finite element model (FLOW 3D) to investigate the movement of water inside the perforated pipe for having better water distribution on top of the bioretention cell for finding the effective length of bioretention cell.

- Perform numerical experiments including sensitivity analysis to simulate and investigate the runoff control performance of a right-of-way bioretention facility.

- Synthesize the numerical experimental results into recommendations for a better design of the bioretention facility regarding the effective length.

\subsection{Organization of Thesis}

The number of chapters in this thesis is six. Chapter 1 discusses the background of this research, definition of problems as well as objective and scopes. Chapter 2 analyses relevant literature, including urbanization impacts, brief history of stormwater management practices, evolution of stormwater management in Ontario, conventional and new stormwater management facilities, best 
management practices (BMP), LID practices in particular bioretention, and stormwater management models. Chapter 3 talks about the research methodology, including different scenarios for modeling. Chapter 4 is the case study (The Queensway Sustainable Sidewalk project). Results and discussions of this study are given in Chapter 5. Finally, conclusions and recommendations for the better design of LIDs practices as well as proposed future related research constitute Chapter 6. 


\section{Chapter 2 Literature Review}

\subsection{Introduction}

As mentioned in chapter 1, urbanization changes the water cycle in nature and causes several adverse environmental problems. From about 1956, cities and municipalities started to construct stormwater drainage systems without any models, codes, and even reliable data. They just used surveying and defined the project using any commercially available pipes (sewers) with the aim of having the cheapest way to move stormwater downstream (James,2018).

Urbanization increases impervious surfaces such as roads, parking lots, roofs. So, urbanization will significantly change the peak flow to very high ones during a storm in a short time and increase the volume of urban runoff. In addition, urbanization reduces the quality of water since the urban runoff accumulates sediments, debris and other pollutants like heavy metals from road surfaces thereby affecting the quality of urban runoff before reaching bodies of water.

Finally, with rapid world urbanization, we need more efficient stormwater practices like LID practices; the urban population in 1900 was $13 \%$ of the total population of the world but in 2030 it will be 60\% (Figure 2-1).

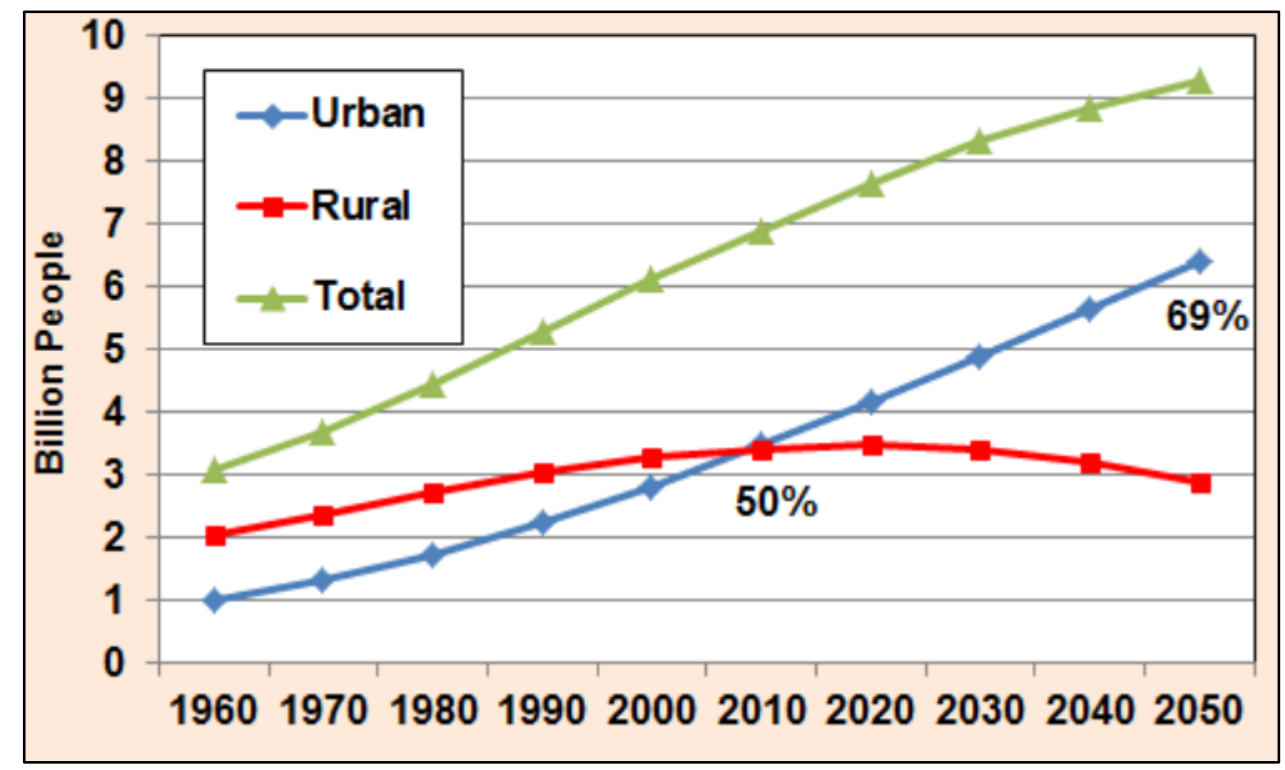

Figure 2-1. Population growth from 1960 to 2050 in urban \& rural areas (James, 2018). 


\subsection{Impacts of Urbanization}

\subsubsection{Stormwater Quantity Impacts}

Most of the runoff in a natural environment is captured by infiltration, evaporation or plant transpiration processes. Urbanization adds stress to natural watercourses and related environments since the increased imperviousness of surfaces like roads, driveways, parking areas, and roofs decreases the infiltration rate and evaporation or plant transpiration (Water Canada, 2009). The relationship between impervious cover and surface runoff illustrated on Figure 2.2 from US EPA.
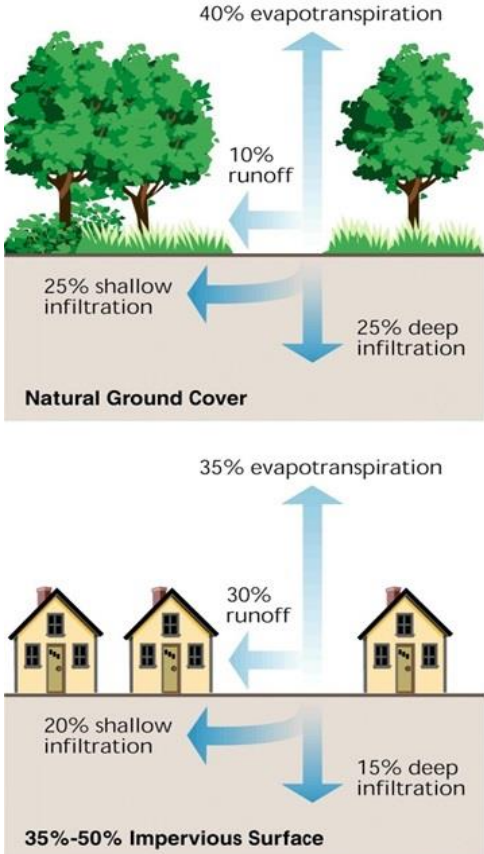

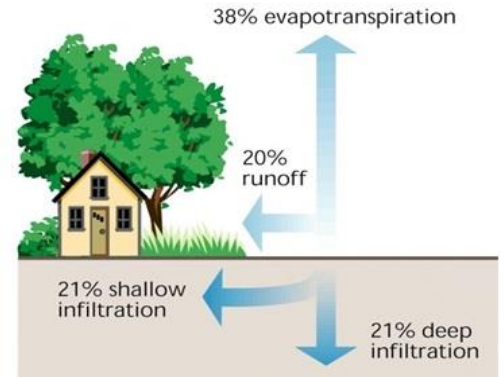

$10 \%-20 \%$ Impervious Surface

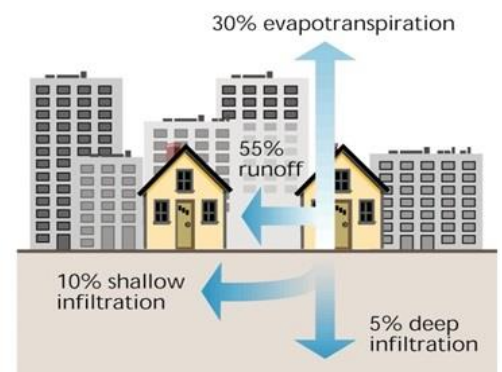

75\%-100\% Impervious Surface

Figure 2-2. Relationship between impervious cover and surface runoff (US EPA, 2007).

Figure 2-3 shows the effects of urbanization on volumes and rates of surface water runoff. As you can see, urbanization will increase the runoff rate and volume and peak flow happens much quicker. So, having the peak flow in a shorter time causes flooding or overflowing storm inlets. The high peak flows, and bigger volumes have a strong effect on the flood frequency and magnitude of the flood -for instance, a 2-year storm event will happen in less than 2 years. 


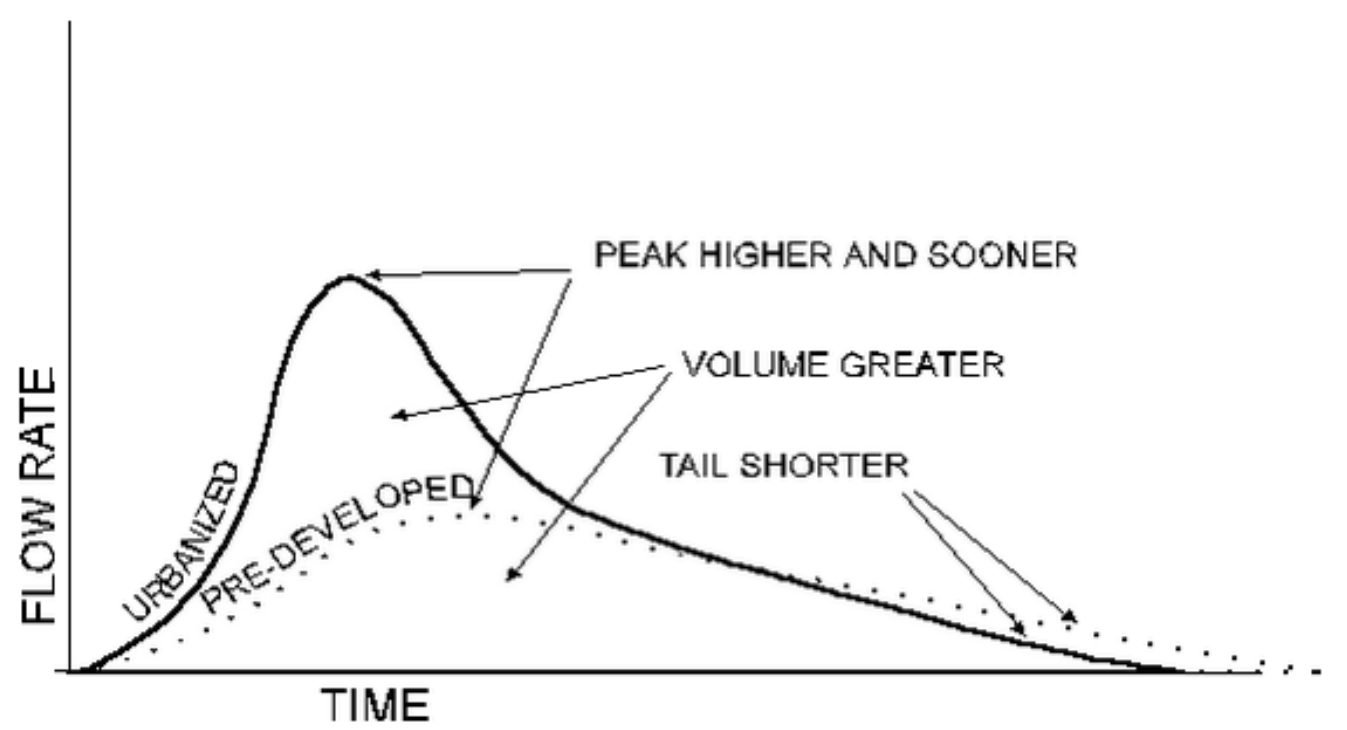

Figure 2-3. Effects of urbanization on volume and rates of surface water runoff (adopted from: Roads and Transportation Association of Canada, 1982).

\subsubsection{Erosion Impacts}

The changes in the natural hydrologic cycle can change the morphology of the stream and cause soil erosion. Soil erosion has become one of several adverse environmental concerns around the world. Human activities as well as natural parameters such as slopes, rainfall, vegetation cover, and soil characteristics, and land-use changes have a huge influence on soil erosion. Recently rapid urban urbanization worldwide in addition to human activities are major reasons for severe soil erosion (Zhang \& Huang, 2015). Channels have widened, and stream directions sometimes changed because of the bank erosion and more stormwater runoff as a result of urbanization (US EPA, 1999).

\subsubsection{Stormwater Quality Impacts}

One of the most harmful forces changing stream health is urbanization; for watershed managers, it is one of their principal challenges (Riley,2008). Levels of heavy metals and nutrients like phosphorus and nitrogen can change water chemistry by urban runoff (Porcella and Sorenson 1980, Morse et al. 2003). Pollutants from both point-source and non-point source from urban runoff can significantly reduce the chemical water quality of urban streams and other receiving waters. With more impervious surfaces in urban areas, contaminants can move much faster through 
increased surface runoff and hydraulic efficiency. Pollutants like nutrient loadings, volatile organic compounds (VOCs), heavy metals, and thermal pollution increase in urban areas. Thermal pollution is a vital parameter especially in the rivers where water temperature has become significant for some species (McGrane,2016). Restricted access to extensive sanitation systems and poor rules and regulations in developing countries can reduce the water quality remarkably by discharging contaminants directly into watercourses from industry, agriculture and untreated domestic wastewater. However, in the developed world, regulations from state, national and international authorities have controlled both point and non-point sources of pollutants to not discharge untreated wastewater directly into watercourses (EUWFD 2001, USEPA 2001).

In addition, urban stream water quality has two phases of the urbanization process. The first phase is associated with receiving the weighty pulse of sediment eroded from upstream development sites even with the presence of erosion and sediment controls. Accumulated deposits from impervious areas will be washed in the second phase and become the main source of contaminants. Ontario's Provincial Water Quality Objectives shows in Table 2-1 compares essential concentrations of contaminants (Ministry of Environment (MOE), 2003).

Table 2-1. Comparison of Urban Stormwater Runoff Concentrations with Provincial Water Quality Objectives (Aquafor, 1993).

\begin{tabular}{|l|c|c|c|}
\hline Parameter & Units & PWQO & Observed Concentrations \\
\hline Fecal coliforms & $\mathrm{CNT} / \mathrm{dL}$ & - & $10,000-16 \mathrm{E} 6$ \\
\hline $\mathrm{SS}$ & $\mathrm{mg} / \mathrm{L}$ & - & $87-188$ \\
\hline $\mathrm{TP}$ & $\mathrm{mg} / \mathrm{L}$ & 0.03 & $0.3-0.7$ \\
\hline $\mathrm{TKN}$ & $\mathrm{mg} / \mathrm{L}$ & - & $1.9-3$ \\
\hline $\mathrm{Phenolics}$ & $\mathrm{mg} / \mathrm{L}$ & 0.001 & $0.014-0.019$ \\
\hline $\mathrm{Al}$ & $\mathrm{mg} / \mathrm{L}$ & - & $1.2-2.5$ \\
\hline $\mathrm{Fe}$ & $\mathrm{mg} / \mathrm{L}$ & - & $2.7-7.2$ \\
\hline $\mathrm{Pb}$ & $\mathrm{mg} / \mathrm{L}$ & 0.025 & $0.038-0.055$ \\
\hline $\mathrm{Ag}$ & $\mathrm{mg} / \mathrm{L}$ & 0.0001 & $0.002-0.005$ \\
\hline $\mathrm{Cu}$ & $\mathrm{mg} / \mathrm{L}$ & 0.005 & $0.045-0.46$ \\
\hline $\mathrm{Ni}$ & $\mathrm{mg} / \mathrm{L}$ & 0.025 & $0.009-0.016$ \\
\hline $\mathrm{Zn}$ & $\mathrm{mg} / \mathrm{L}$ & 0.030 & $0.14-0.26$ \\
\hline $\mathrm{Cd}$ & $\mathrm{mg} / \mathrm{L}$ & 0.0002 & $0.001-0.024$ \\
\hline
\end{tabular}


As you can see in Table 2-1, sediments and nutrients are major parameters. Channel erosion is affected by the amount of the sediment load. Having high levels of suspended solids in both organic and inorganic matter will have several other effects on a receiving body of water (Ministry of Environment (MOE), 2003). Nutrients also play a vital role in water quality. Nutrients traditionally are the major pollutant in agricultural runoff. However, high concentrations of nutrients after urbanization coming from fertilizer applications on lawns, golf courses, and municipal recreation parks are the reason for the reduction of DO (dissolved oxygen), ammonia and nitrate toxicity (Liu, 2016). Table 2-2 shows nutrient concentration at the inlet of stormwater treatment facilities from various studies.

Table 2-2. Nutrient concentration and guidelines at the inlet of stormwater treatment facilities.

\begin{tabular}{|c|c|c|}
\hline Type of Nutrient & $\begin{array}{c}\text { Concentration at the Inlet of SWM } \\
\text { Facilities }\end{array}$ & Guidelines \\
\hline Nitrate Nitrogen & $\begin{array}{c}0.203-1.6 \mathrm{mg} / \mathrm{L}(\text { Mayer, Marsalek, \& Reyes, } \\
1995) ; 0.2-1.3 \mathrm{mg} / \mathrm{L} \text { (Mallin et al., 1992) }\end{array}$ & $\begin{array}{c}<10 \mathrm{mg} / \mathrm{L} \text { (Environmental } \\
\text { Canada, 1984) }\end{array}$ \\
\hline Ammonia Nitrogen & $\begin{array}{c}0.013-1.082 \mathrm{mg} / \mathrm{L} \text { (Mayer, Marsalek, \& Reyes, } \\
1995) ; 0.1-0.2 \mathrm{mg} / \mathrm{L} \text { (Stanley, 1996) }\end{array}$ & $\begin{array}{c}<0.5 \mathrm{mg} / \mathrm{L} \text { (Environmental } \\
\text { Canada, 1994) }\end{array}$ \\
\hline Phosphate & $0.007-0.48 \mathrm{mg} / \mathrm{L}$ (Mayer, Marsalek, \& Reyes, \\
Phosphorus & $\begin{array}{c}\text { Excellent, if }<0.1 \mathrm{mg} / \mathrm{L}(\mathrm{Center} \\
\text { of Earth and Environmental } \\
\text { Science, 2005) }\end{array}$ & \\
\hline
\end{tabular}

\subsubsection{Aquatic Habitat and Ecology}

Urbanization impacts on in-stream ecological communities have been investigated by several comprehensive reviews such as Paul and Meyer (2001), Walsh et al. (2005), O'Driscoll et al. (2010). Aquatic ecosystems are affected by reducing the quality of the urban streams via geomorphological and chemical changes to surface water bodies (McGrane,2016). Urbanization has adverse effects on aquatic habitats like reducing baseflow, flow depth and velocity, and poor water quality. Results of the research showed harm to diversity, richness, and biotic integrity and caused the disappearance of the most sensitive species and decreased the number of tolerant species (Wenger et al., 2009). In the area of urban water ecosystems, urbanization has a huge 
influence on the population of some sensitive fishes and Macroinvertebrates (Walsh et al. 2005) (Refer to Figure 2-4).

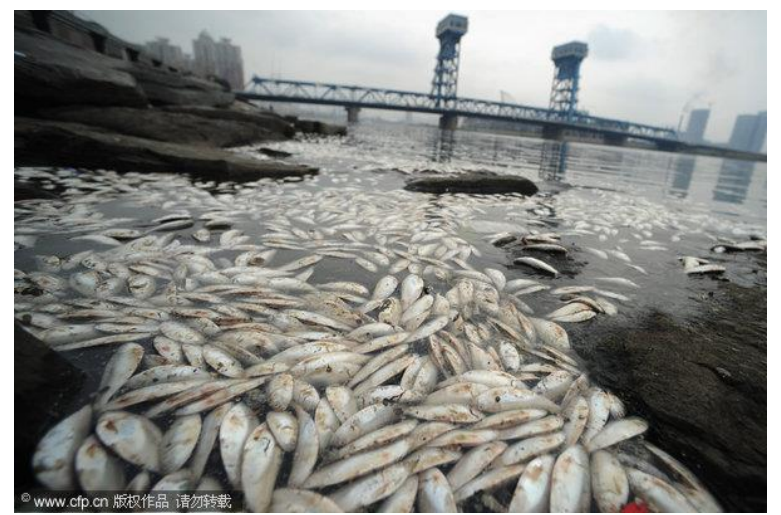

Figure 2-4. Masses of dead fish float in the Haihe River in North China's Tianjin municipality due to increase in contaminants in the river water .

\subsection{Evolution of stormwater management in Ontario}

Stormwater management practices were an essential component of controlling runoff quantity and quality for reducing the adverse effects of urbanization (The Municipal Infrastructure Group Ltd.; Schollen \& Company Inc., 2011). Peak flow control and runoff volume reduction were the initial aims of stormwater management practices in Ontario for flood control, and stormwater management practices but only based on minor systems. After a while, major systems were applied to reduce the size of the minor systems and this change saved a lot of money (Watt et al., 2003).

As a result of urbanization, erosion and sediment loading were the main problems in the early 1990s. Also, stormwater management practices combined with urban development with consideration of land use and environmental impacts (MOE, 2003). The Low Impact Development Stormwater Management Planning and Design Guide suggested four major aspects for stormwater management practices in the late 1990s: water quality, erosion control, aquatic habitat, and baseflow maintenance (Credit Valley Conservation (CVC), TRCA, 2010).

Ontario's Ministry of Environment published the Stormwater Management Planning and Practices Manual (2003). They presented some new and existing stormwater management techniques. The Environmental Bill of Rights considered the impacts of climate change in new stormwater management practices in 2007. Recently, climate change, as well as LID and water budget, are parts of novel Stormwater management developments (Credit Valley Conservation (CVC), TRCA, 
2010). The evolution of stormwater management in Ontario from 1980 to present shown below in Figure $2-5$.

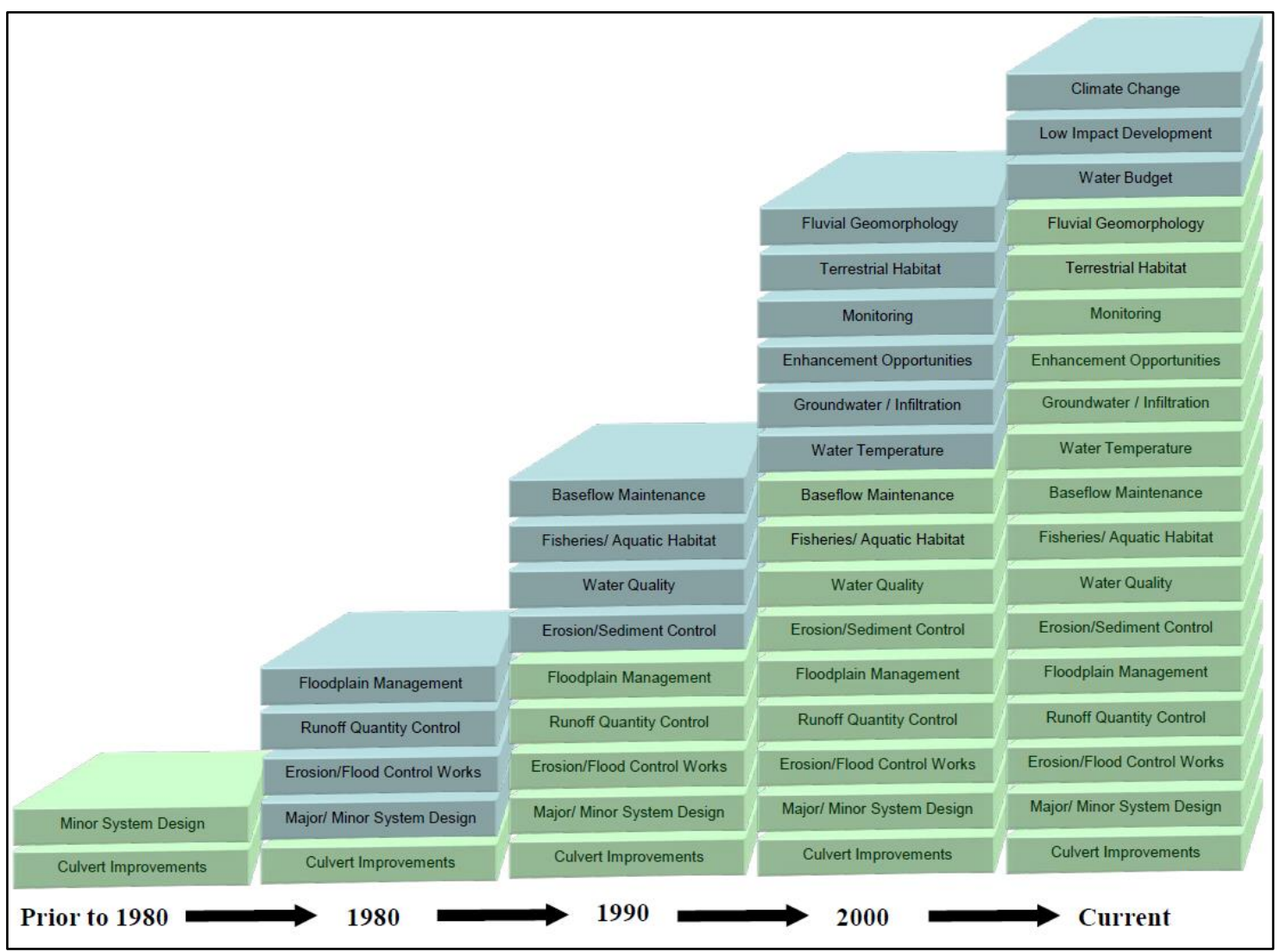

Figure 2-5: Evolution of stormwater management in Ontario from 1980 to Present (TRCA, Adapted from MOE,1993).

\subsection{Conventional and new stormwater management facilities}

For protecting the environment and watershed, the conventional (traditional) storm sewer pipe network can't satisfy the major objectives and properly control the runoff from storm events. (Ternier, 2012). Therefore, stormwater best management practices (BMPs) and LID have been established to resolve defects of the existing (conventional) storm sewer pipe network. Source control (lot level), conveyance control, or end-of-pipe control are three chief aspects of these practices (MOE, 2003).

Within the site development's boundaries, source control practices have been applied as a preliminary level of control with two different types: 1- Storage control 2-Infiltration-based 
control. The application of storage practices can be applied on rooftops as green roofs and under parking lots and backyards (MOE, 2003). Reduced grading, downspout disconnections, infiltration trenches, grassed swales, open ditches, pervious pipe systems, vegetated filter strips, stream/valley corridor buffer strips, oil/grit separators, permeable pavements, rain gardens and bioretention cells are considered infiltration-based practices (MOE, 2003; CVC \& TRCA, 2010).

Conveyance control BMPs are basically connected directly to the stormwater conveyance system and they have over-sizing storm sewers to create extra storage, ditches and concrete basins (Dubyk, 1994; MOE, 2003).

The ultimate level of stormwater control is the end of pipe control. The conveyance system is transferred stormwater and then the treatment is applied and later released into bodies of water. End of pipe facilities comprise wet ponds, wetlands, dry ponds and infiltration basins (MOE, 2003).

BMPs are not able to satisfy all stormwater objectives. A combination of different approaches is essential during the selection of a site. A treatment train approach is recommended since stormwater first faces source controls to control the runoff following by conveyance and end of pipe control (MOE, 2003) (Figure 2-6).

In order to choose the right BMP that could fulfill different objectives, MOE in 2003 published a table in 'Stormwater Management Planning and Practices Manual,'. Table 2-3 shows different BMPs approaches and their related objectives. 
Table 2-3. List of stormwater management practices to aid practioners in selecting practices according to the objectives they fulfill (MOE, 2003; Aquafor, 1993).

\begin{tabular}{|c|c|c|c|c|}
\hline SWMP & $\begin{array}{c}\text { Water } \\
\text { Balance }\end{array}$ & $\begin{array}{c}\text { Water } \\
\text { Quality }\end{array}$ & Erosion & $\begin{array}{c}\text { Water } \\
\text { Quantity }\end{array}$ \\
\hline \multicolumn{5}{|c|}{ Lot Level and Conveyance Controls } \\
\hline Rooftop storage & $\mathrm{F}$ & $\mathrm{F}$ & $\mathrm{F}$ & M \\
\hline Parking lot storage & $\mathrm{F}$ & $\mathrm{F}$ & $\mathrm{F}$ & M \\
\hline Superpipe storage & $\mathrm{F}$ & $\mathrm{F}$ & $\mathrm{F}$ & $\mathrm{M}$ \\
\hline Reduced lot grading & M & - & - & $\mathrm{F}$ \\
\hline Roof leader to ponding area & $M$ & - & - & $\mathrm{F}$ \\
\hline Roof leader to soakaway pit & $\mathrm{M}$ & - & - & $\mathrm{F}$ \\
\hline Infiltration trench & M & M & - & $\mathrm{F}$ \\
\hline Grassed swales & M & - & • & • \\
\hline Pervious pipes & M & M & - & $\mathrm{F}$ \\
\hline Pervious catchbasins & M & - & • & $\mathrm{F}$ \\
\hline Vegetated filter strips & $\mathrm{M}$ & - & - & $\mathrm{F}$ \\
\hline Natural buffer strips & • & • & • & $\mathrm{F}$ \\
\hline Rooftop gardens & $\mathrm{F}$ & $\cdot$ & $\cdot$ & $\mathrm{F}$ \\
\hline \multicolumn{5}{|l|}{ End-of-Pipe Controls } \\
\hline Wet pond & $\mathrm{F}$ & $M$ & $M$ & $M$ \\
\hline Artificial Wetland & $\mathrm{F}$ & $\mathrm{M}$ & $\mathrm{M}$ & $\mathrm{M}$ \\
\hline Dry pond & $\mathrm{F}$ & • & $M$ & $\mathrm{M}$ \\
\hline Infiltration basin & - & M & • & $\mathrm{F}$ \\
\hline Filters* & $\mathrm{F}$ & $\mathrm{M}$ & $\mathrm{F}$ & $\mathrm{F}$ \\
\hline Oil/grit separators* & $\mathrm{F}$ & - & $\mathrm{F}$ & $\mathrm{F}$ \\
\hline
\end{tabular}

M High Suitability • Medium Suitability F Low Suitability *Water Quality suitability is highly dependent on sizing and by-pass design. 


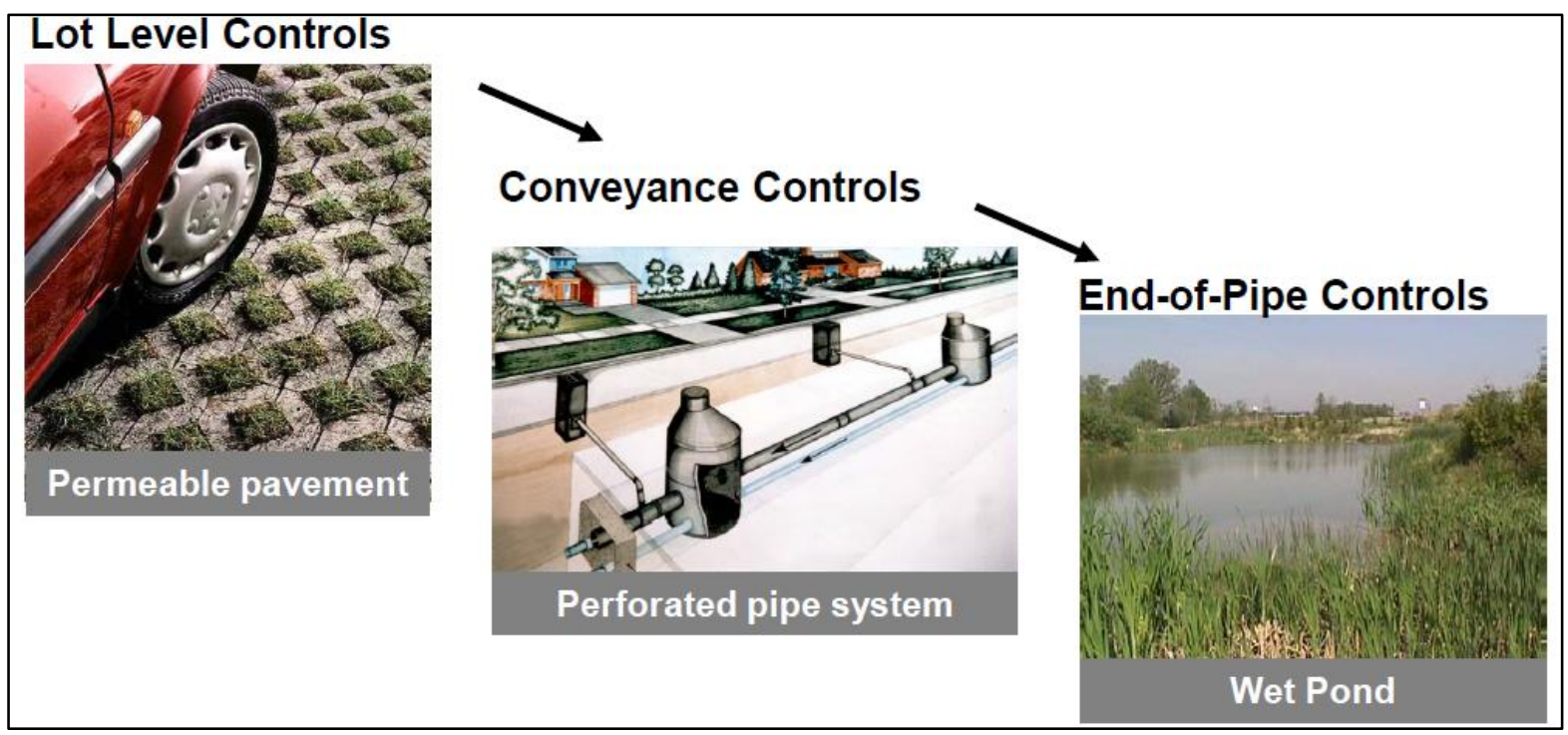

Figure 2-6: Mitigation of adverse environmental impacts by using "treatment train". (TRCA, 2014)

\subsection{Best management practices (BMP)}

Methods, practices, measures or structural controls are those that control stormwater runoff in both quantity and quality (US EPA, 1999). Historically, BMPs have emphasized water quality issues because of urbanization and increasing impervious surfaces.

For satisfying several objectives such as restoring and maintaining the chemical, physical, and the biological integrity of the Nation's waters, the Federal Water Pollution Control Act was established in 1972. Amendments in 1977, 1982, and 1987 didn't change the objectives and the Act later became the Clean Water Act (CWA) (US EPA, 1993). The separation of point and nonpoint sources of pollution and the reliance on BMPs for nonpoint sources were one of the significant decisions made by the United States Congress in the 1972 Federal Water Pollution Control Act Amendments (Ice, 2004). End-of-pipe flow or flows from a “ ‘...discernible, confined, and discrete conveyance, including but not limited to any pipe, ditch, channel, tunnel, conduit, well, discrete fissure, container, rolling stock, concentrated animal feeding operation, or vessel or other floating craft from which pollutants are or may be discharged' are considered as point sources. (Tetra Tech, 2001). In addition, some type of effluent treatment and/or process control had to be applied on these discharges under National Pollution Discharge Elimination System (NPDES) permits. However, nonpoint sources were allowed under permission of NPDES and they are very scattered. 
For regulating nonpoint sources of pollution, BMPs are broadly well-known practices since BMPs diminish or avoid contaminants rather than directly solve it. However, a comparison of the performance of BMPs and process controls that are applied to treatment of effluent, shows there are still doubts regarding the application of BMPs over process controls treatment for point sources (Ice, 2004).

A basic definition of BMP is a practice or mixture of practices regulating via investigation of alternative practices, problems evaluation, and proper public participation to have best impacts on these issues. Also, practical methods like technological, economic, and institutional considerations for addressing contaminants in water produced by nonpoint sources have been used to fulfill the regulations. water quality goals (U.S. Department of Agriculture (USDA) Forest Service, 1980). A combination of operative pollution control methods and practical management considerations is the best example of a representation of Best management practices. This understanding can be established by providing and answering different types of questions regarding decisions about efficient design of streamside management zones (Ice, 2004).

\subsection{Low impact development (LID)}

Low Impact Development- or in short form LID- is a method for having a better design in terms of suitability for imitating the predevelopment hydrologic cycle by using different practices to make a comparable hydrologic landscape (US EPA, 2000). By using the distributed micro-scale stormwater retention and detention areas, reduction of impervious surfaces, and lengthening flow paths and runoff time, the hydrologic factors including functions of storage, infiltration, ground water recharge, and the volume and frequency of discharges, will be controlled (Coffman, 2000).

The development of traditional stormwater practices and the impacts on the urban hydrologic cycle have been recognized for years (Dietz, 2007). Urbanization causes growth in impervious surfaces as well as more surface runoff (Hollis 1977; Jennings and Jarnagin 2002; Waananen 1969). Also, it boosted runoff velocity (Leopold 1968), and degraded water quality (Makepeace et al. 1995; US EPA 1983). Increasing runoff from urban areas was recognized in the late 1800s (Kuichling 1889) and still remains one of the main issues in the United States' waterways and all over the world (US EPA 2002). 
LID was first introduced in Maryland in 1999 for reducing the adverse impacts of urbanization which was caused by more impervious surfaces (Prince George's County, 1999). The general objective of LID is the conservation of the predevelopment hydrology of a site. Compared to traditional stormwater design, LID practices offer a variety of site designs in the different planning phases.

The new site design doesn't change any hydrologic and hydraulic conditions but do decrease the negative effects to the soils, vegetation, and aquatic systems on the site if any changes are made. On the other hand, traditional stormwater practices mainly emphasize reducing the peak flow rate. In addition, predevelopment runoff volume can be maintained by using the new practices such as LID (Dietz, 2007).

The area linked to the stormwater system is called an "effective impervious area" of a watershed and cluster layouts, grass swales, rain gardens/bioretention areas, and pervious pavements diminish this area (Booth and Jackson 1997).

"Initial research on individual LID practices has shown promising results", while later studies have demonstrated new successes, as well as some unexpected outcomes (Dietz, 2007). This has led to questions regarding LID suitability across varied sites, its impact on groundwater and suitability in winter conditions.

\subsubsection{History of Low Impact Development in North America}

As an alternative to grey infrastructure, LID was introduced and applied in the northeastern United States and the Pacific Northwest as a novel design strategy. After a while, it became widespread throughout the United States (CWP, 2000; Horner et al., 1997). The first implementation of LID practice was constructed around thirty years ago (1999) in Prince George's County, Maryland and is still considered a new approach (Prince George's County Government, 1999).

Fifteen LID projects in eight different states were reviewed by Morzaria-Luna et al. (2004); almost half of them were in new development areas and the other half implemented as retrofit projects in conventional urban areas. Also, utilization of a LID design in British Columbia was reported by Graham et al. (2004). 
Several LID projects have been implemented across the United States and these field monitoring projects such as Maryland (Davis et al., 2003), New Hampshire (Rossen et al., 2006), North Carolina (Hunt et al., 2006), Ohio (Sansalone and Teng, 2004), and Pennsylvania (Heasom et al., 2006) have had effective results. In recent years, almost thirty stormwater management manuals and guidelines with the latest approaches and practices have been published but many of them mostly reviewed technical aspects than other aspects like economic, cultural, and social impacts (Lawson, 2010).

\subsubsection{Low Impact Development in Ontario}

Four out of five Great Lakes (Lake Ontario, Lake Erie, Lake Huron \& Lake Superior) are within Ontario's borders. Ontario also has more than 250,000 lakes, rivers, and streams with a rich groundwater resource (Ontario Ministry of Environment (MOE),2003). The Ontario government established several acts and regulations such as the Ontario Water Resources Act (R.S.O. 1990, c. O.40), Clean Water Act 2006 (S.O. 2006, c. 22), and Environmental Protection Act (R.S.O. 1990,

c. E.19) for proctoring drinking water and protecting bodies of water from contamination (Lawson, 2010).

In addition, for guiding municipalities, community groups, businesses and individuals, the Ontario Ministry of Environment has published some documents and guidelines such as 'Understanding Stormwater Management: An Introduction to Stormwater Management Planning and Design (2003)', 'Stormwater Management Planning and Design Manual (2003)', and 'Stormwater Pollution Prevention Handbook (2001)' for reducing contamination at its source.

For designing and planning LID in Ontario, the Stormwater Management Planning and Design Manual (2003) is still the main guideline for new development as well as retrofit projects. This manual hasn't changed for about 15 years and some of the design criteria are outdated. However, Denich et al. right now are working on "the New Ministry of the Environment and Climate Change Low Impact Development Stormwater Management Manual" and they will publish it by mid-2018 (Denich et al., MOECC, 2018). The Credit Valley Conservation (CVC) and the Toronto and Region Conservation Authority (TRCA) published the "Low Impact Development Stormwater Management Planning and Design Guide" in 2010. This is a comprehensive manual for integrated 
LID design technique, requirements, detailed design criteria, BMP sizing, and cost estimation of different LID designs.

Infiltration-based stormwater controls must operate normally in winter conditions to be practical in Ontario cities. LID parameters will be functional in colder months though with limited capacity (Hunt et al., 2006). According to low evapotranspiration in winter, the infiltration rate decreases to 0.46 in winter- from 0.93 in summer. Hunt et al. (2006) proved that LID elements continue to function in colder months with reduced capacity. At a monitoring site near Philadelphia under winter conditions, the hydraulic conductivity of soil absorbing water was almost half the summer value (Heason et al., 2006).

The infiltration-based BMP is operating adequately under winter conditions in the Connecticut, Pennsylvania, and New Hampshire monitoring sites like the ones in Central Ontario (Roseen et al., 2006). Most studies and results in Ontario are based on Southern Ontario conditions. Therefore, LID practices probably can't operate very well in colder Northern Ontario since there's no study and monitoring site in this area to prove it. In this thesis, snow accumulation and melting will not be considered for the simulations and only rainfall data from April to October for continues simulation as well as design storm with different return period (year) will be used.

In Ontario, LID projects have not been applied broadly since it's a new approach and considered as an experimental approach. Municipalities and professionals in the development business need to spend adequate time to get familiar with the LID approach for applying LID extensively. In addition, LID is usually considered a small treatment approach and there is no clear design criteria and performance as large end-of-pipe designs (Zheng, 2013). The MOE 2003 Stormwater Management Planning and Design Manual does not have enough details for integrating LID within the treatment train (ICF Marbek,2012). Figure 2-7 demonstrates different LID projects in Ontario. Thirty-eight different LID projects were constructed and most of them were in public lands, and industrial and commercial lands. 


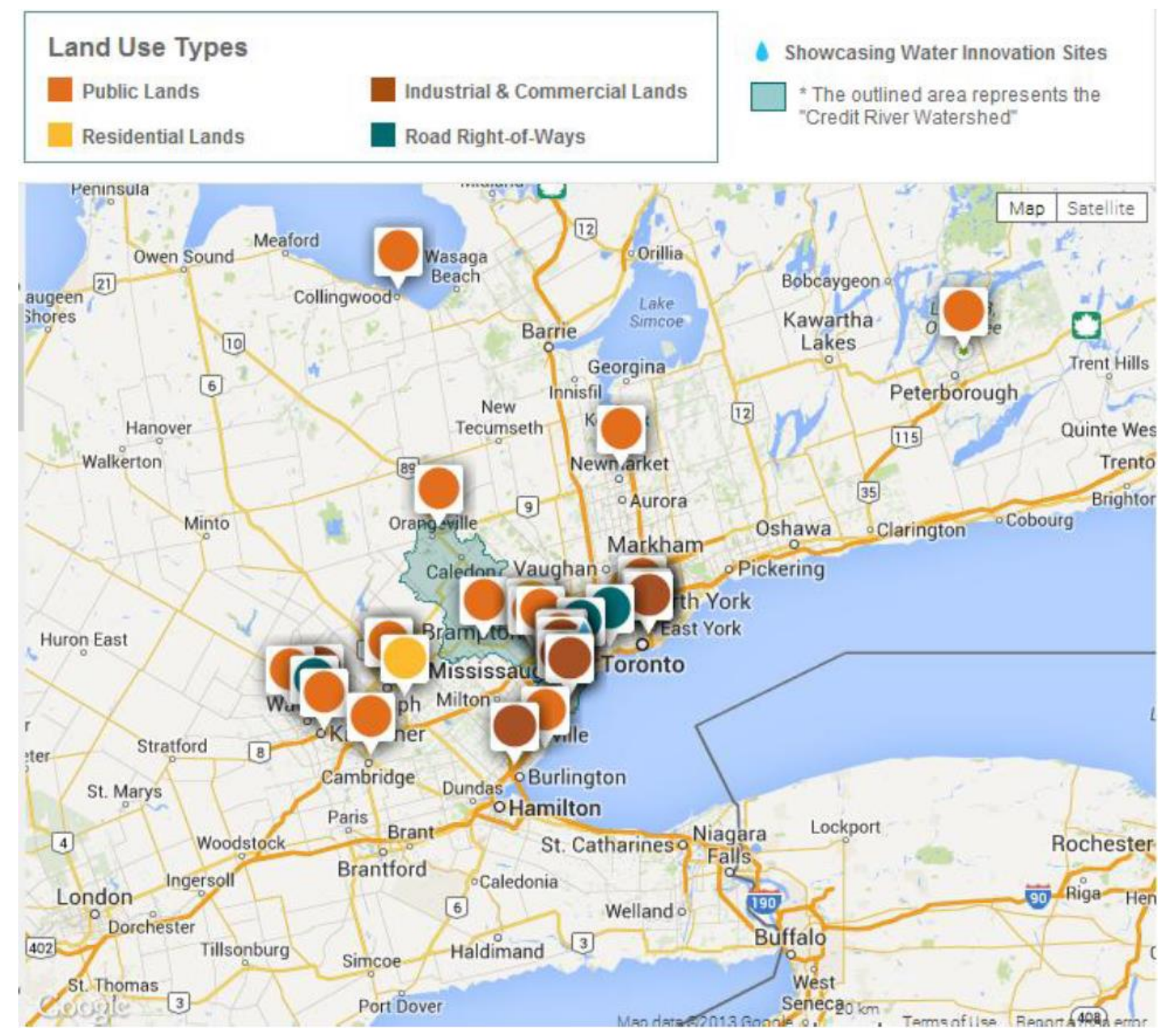

Figure 2-7: Sites implemented LID in Ontario (Credit Valley Conservation, 2013)

\subsection{Bioretention}

Bioretention as an efficient LID practice has received significant interest in recent years. Bioretention can be considered of the most promising LID practices that maintains the fundamental hydrologic functions in a natural environment and can be integrated into neighborhood landscaping.

\subsubsection{What is Bioretention}

Bioretention is a small treatment approach for controlling both water quality and water quantity for eliminating contaminants from stormwater runoff via chemical, biological, and physical characteristics of plants, microbes, and soils. Sedimentation, adsorption, filtration, volatilization, 
ion exchange, decomposition, phytoremediation, bioremediation, and storage capacity are a series of processes that happen in a bioretention facility (Prince George's County, 2009).

Traditionally, a bioretention facility has three different layers: $\bullet$ Surface layer $\bullet$ Soil layer -Storage layer

Also, there's an optional underdrain for collecting excessive water for returning to storm sewers or infiltrates to native soil. A soil layer usually consists of approximately $0.7-1.0 \mathrm{~m}$ of a porous media, composed of a sand/soil/organic matter mixture. The surface layer has a thin layer of standard hardwood between 2.5-8 cm (Prince George's County, 2001). To have better evapotranspiration, preserve soil porosity, boost biological activity, have more uptake of contaminants, different grasses, shrubs, and small trees have been used. Different kinds of healthy vegetation are also needed in terms of the aesthetics of the bioretention facility (Davis, 2008). Different layers of bioretention shows in Figure 2-8 below:

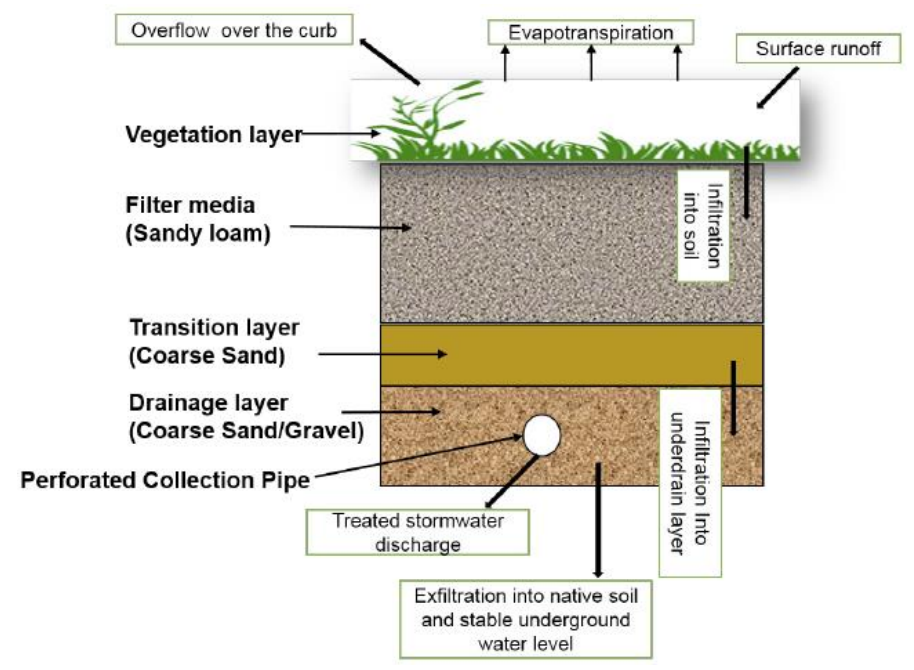

Figure 2-8: Bioretention layers and hydrologic function of a bioretention facility (Shafique, 2016).

Bioretention can imitate the predevelopment hydrologic conditions by treating the associated volumes of runoff while other practices only focus on controlling peak discharge. One of the chief reasons for developing a novel, holistic development philosophy known as LID is the bioretention technique. The bioretention technique is the only LID that considers both peak discharge control and redistributes runoff volume over a longer period of time (Prince George's County, 2009). 
Bioretention has several advantages: rather than controlling water quality and quantity, it can improve the environment by adding various values of landscape diversity to a development such as (Prince George's County, 2009):

- Creating a unique environment by planting native plants in the area.

- Inspiring people to take care of their community and having community pride.

- Providing habitat for wildlife and native plants, saving a lot of energy, improving air quality, reducing adverse effects of urban climates.

- Creating a novel environment by adding aesthetically pleasing landscapes.

- Increases real estate values up to 20 percent by using aesthetically pleasing landscaping.

Figure 2-9 illustrates various types of bioretention in Canada and the United States.
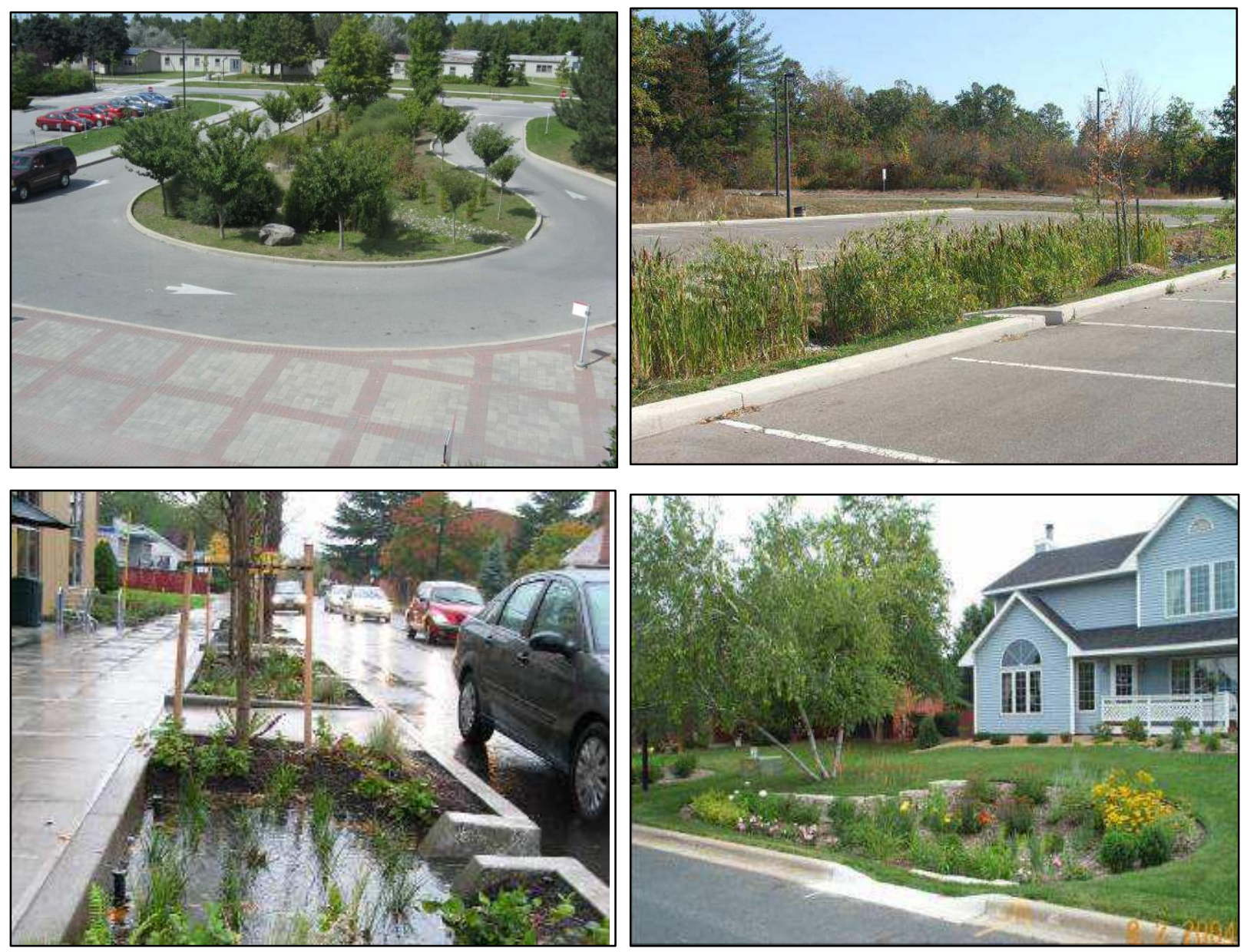

Figure 2-9: Different types of Bioretention in Canada \& the United States (U.S.) (TRCA \& CVC, 2010) (Davis et al., 2009). 


\subsubsection{Bioretention Pollutant Removal}

There are limited data on the performance of bioretention facilities, but it has become more plentiful recently. Performance results from both laboratory and field studies demonstrate that bioretention facilities are one of the most efficient BMPs in pollutant removal. However, examining the performance of the bioretention and other stormwater BMPs can be challenging since there are several different conditions happening during runoff events (Davis et al., 2009). In brief, here are the different pollutants that can be treated by bioretention facilities: $\bullet$ Nitrogen and Phosphorus Removal • Oil and Grease Removal • Heavy Metal Removal (Copper, lead, and zinc etc.) - TSS Removal - Removal of BOD and Pathogens - Removal of PAHs (polycyclic aromatic hydrocarbons). Table 2-4 demonstrates reported pollutant removal performance of bioretention systems:

Table 2-4. Reported Pollutant Removal Performance of Bioretention Systems (Prince George's County, 2009).

\begin{tabular}{|c|c|c|}
\hline Parameter & \% Removal & Source(s) \\
\hline TSS & 97 & Hsieh and Davis, 2005; UNHSC, 2006 Ermillio \& Traver, \\
& & 2006 \\
\hline TP & $35-65$ & Davis et al., 2006; Hunt, et al., 2006 Ermillio, 2005 \\
\hline TN & $33-66$ & NHSC, 2006; Hunt et al., 2006 Sharkey, 2006, Davis et al., \\
& & 2006 \\
\hline $\mathrm{Cu}$ & $36-93$ & Ermillio, 2005; Davis, et al., 2006 \\
\hline $\mathrm{Pb}$ & $24-99$ & Ermillio, 2005; Davis, et al., 2006 \\
\hline $\mathrm{Zn}$ & $31-99$ & UNHSC, 2006; Ermillio, 2005 \\
\hline Oil \& Grease & 99 & UNHSC, 2006; Hong, et al., 2006 \\
\hline Bacteria & 70 & Hunt, et al., 2007 \\
\hline
\end{tabular}

\subsubsection{Bioretention Soil and its Functions}

Bioretention facilities are composed of soil and different kinds of vegetation that help to remove contaminants by several treatment procedures (Davis, 2008). As mentioned before, a bioretention facility has a soil layer of about $1 \mathrm{~m}$ - a porous media consisting of soil/organic matters.

On the surface layer, there's a thin layer of standard hardwood mulch. The soil layer has three different phases of liquid, gas and solid particles. Each phase contributes to the treatment process of the stormwater runoff. For better water quality, the soil needs to be selected appropriately 
depending on the location of the site and its limitations since the soil plays a vital part in the filtering process (Abida et al., 2007) (Hinman, 2009).

The mulch layer has a significant role in removing most of the heavy metals on the top of each bioretention facility. In addition, heavy metals are absorbed by organic matter in this layer. The phosphorus removal rate depends on the depth of the soil layer and rises linearly and can be maximized at the depth of $1 \mathrm{~m}$ (Prince George's County, 2007).

For removing the phosphorus from the soil, the treatment process relies on the amount of aluminum and iron in the soil. The TKN (nitrogen) removal process depends on the soil depth (USEPA, 2000). Different types of bioretention facilities have different nitrate removal efficiency. Also, solid particles won't be in a suspension phase since the lower velocity of the runoff in bioretention facilities and sedimentation issue appears in this condition (Trowsdale \& Simcock, 2011). A monitoring study at University of Virginia was done and there are convincing results for removal rates of this bioretention cell (Akan \& Houghtalen, 2003) (USFHWA, 2013):

- Total Suspended Solids (TSS) removal=86\% • Chemical Oxygen Demand (COD)=97\% • Oil and Grease removal $=67 \%$

Based on the results on these studies, a shallow bioretention with a thick mulch layer is recommended for treating high concentration of heavy metals. In residential areas, the main pollutants are nitrogen and phosphorous. The depth of the bioretention is the determinative factor. (Trowsdale \& Simcock, 2011) (Paquette, 2012).

\subsubsection{Soil Restriction}

An appropriate mix design of soil should be selected in order to have an efficient LID for controlling stormwater in the selected area (Paquette, 2012). Redistribution of the water in the whole system and retaining the water to filter out the large particles and pollutants are the main intention of the bioretention facilities. The quality of runoff increases as well as reduction of the cost of treating the water at the end-of-pipe system. The soil of the biorientation cell should have a satisfactory infiltration rate to increase the dewatering rate on the surface layer, have proper infiltration rates for having efficient pollutant removal in the soil, and offer a media zone for providing nutrient for plants and vegetation (Prince George's County, 2009). According to the Bioretention Manual (Prince George's County, 2009), the type of soil should satisfy the following 
criteria: - Captured water should leave the system in 48 hours - Minimum infiltration rate of 12 $\mathrm{mm} / \mathrm{hr}$. The Bioretention Manual suggests USDA soil textural classifications demonstrated in Table 2-5:

Table 2-5. Soil textural classification (Prince George's County, 2009).

\begin{tabular}{|c|c|c|}
\hline Texture Class & $\begin{array}{c}\text { Minimum Infiltration Rate } \\
(\mathbf{m m} / \mathbf{h r} .)\end{array}$ & Hydrologic Soil Group \\
\hline Sand & 210 & $\mathrm{~A}$ \\
\hline Loamy Sand & 61.2 & $\mathrm{~A}$ \\
\hline Sandy Loam & 25.90 & $\mathrm{~A}$ \\
\hline Loam & 13.20 & $\mathrm{~B}$ \\
\hline
\end{tabular}

Hinman et al. (2009) studied the bioretention soil design mix and found that the hydraulic conductivity of bioretention soil relies on the percent mineral aggregate passing through a 200 sieve. The amount of fine aggregate also should be less than 5\% (USEPA, 1999). The hydraulic conductivity of the bioretention soil is sensitive to compaction of percentage fines and grading of the selected mix design (Hinman et al, 2009). Compaction value (e.g. $85 \%$ of maximum dry density) is usually chosen by considering the real field conditions in bioretention facilities such as no regular foot traffic (pedestrian crossing) (Prince George's County, 2009). According to Figure 2-10, the hydraulic conductivity of the soil decreased when fine particles in the mixtures increase (Uddin, 2012). Having more fine particles in the mixture causes the elimination of pores and void space in the soil and a poor percolation of water through the soil.

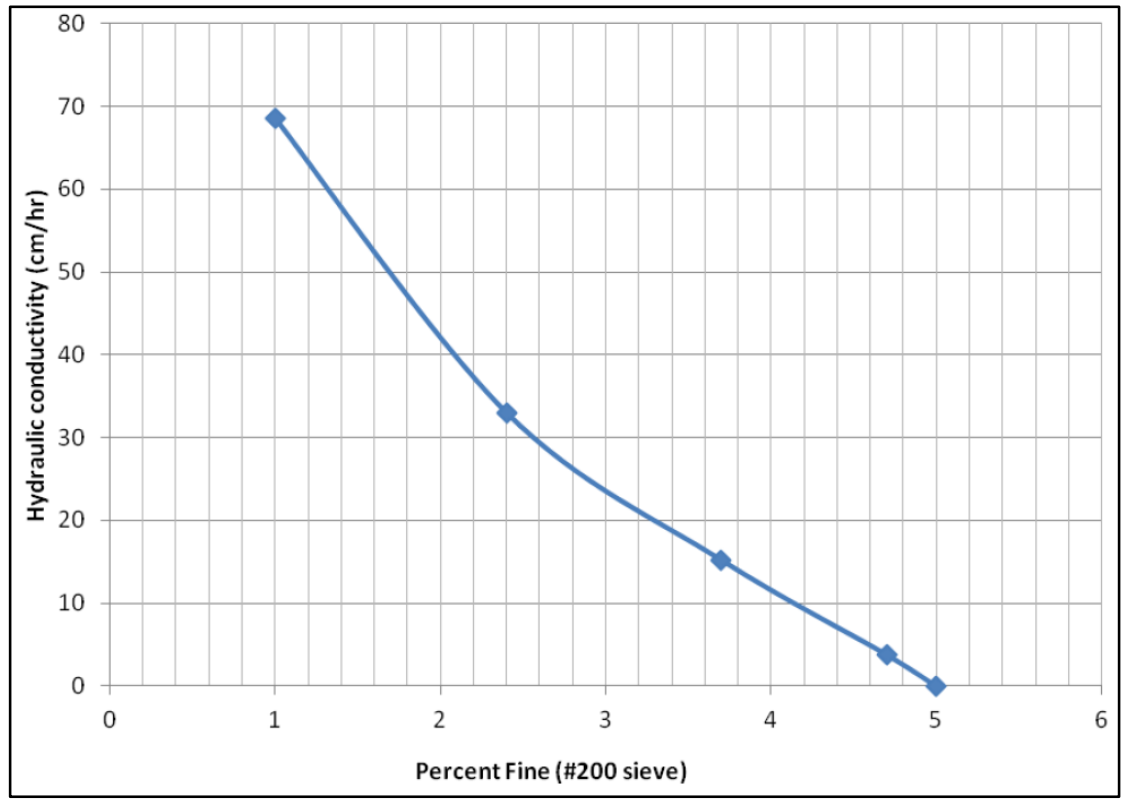

Figure 2-10: Percent fines and hydraulic conductivity relationship (Uddin, 2012). 
The soil is categorized according to its characteristics and there are three soil classifications: loamy sand, sandy loam, and loam that is very popular in the biorientation facilities. One of the soil types that meets the required infiltration rate $(13.2 \mathrm{~mm} /$ hour $)$ for bioretention facilities is sandy soil. However, there are some issues associated with dry soil and plant survival since there is high hydraulic conductivity of sandy soil (about $210 \mathrm{~mm} /$ hour) (Prince George's County, 2009). Clar et. al (1993) suggested a mixture of $60 \%$ sand, $20 \%$ aged organic materials and $20 \%$ other materials like additives.

To protect the underdrain and reduce the effects of the clogging factor, the gravel bed is applied underneath the bioretention cell. Recommended properties for the gravel bed are mentioned below (Prince George's County, 2009):

- The size of gravel should be between 12 to $40 \mathrm{~mm}$ (diameter). The thickness of the gravel layer should be less than $300 \mathrm{~mm}$. - Washed and river-run gravels are recommended for this layer. The amount of the carbon in the soil mixture plays a significant role in the performance of a bioretention facility and the best performance of a bioretention cell is achieved with high carbon and low fertility. The soil mix design suggested by the bioretention manual (Prince George's County, 2009) should have 50\% sand, 30\% topsoil and $20 \%$ organic material. The higher amount of organic matter in the soil mix design has positive impacts on the phosphorus removal procedure (Bratieres et al., 2008).

For maintaining the water quality performance of a bioretention facility, the mulch layer must be changed occasionally. The mulch layer on the surface layer pre-treats the captured runoff by treating TSS (Total Suspended Solids), avoiding clogging of the porous space in the soil layer, keeping soil moisture constant and increasing more nutrients for vegetation (Davis et al., 2009). The water storage layer and groundwater recharge are improved by adding gravel to the soil mix design of the bioretention soil.

\subsubsection{Sizing of the bioretention facilities}

Many studies have been done on the sizing of the bioretention facilities and many local design guidance manuals have different criteria for minimum and maximum values of width and length of the bioretention as shown in Table 2-6 (Lucas, 2005). In 1993, a minimum width range of 3000$4500 \mathrm{~mm}$ and a minimum length of 9000-12000 mm was suggested by Prince George's County 
and most of the local manuals still follow these recommendations (Clar, et al, 1993). Nevertheless, practical experience shows that the real minimum width is only $1200 \mathrm{~mm}$. This system can be a bioretention cell with a $610 \mathrm{~mm}$ bottom width, $150 \mathrm{~mm}$ ponding depth and 2:1 side slope and no freeboard allowance. The minimum width will increase to $1830 \mathrm{~mm}$ if a freeboard depth of 150 $\mathrm{mm}$ is applied. This bioretention facility with the above dimensions can be found in a residential lot for treating runoff from a roof downspout or driveway. In addition, practical experience also recommended that there is no scientific limit on a maximum value for length and width. However, the real maximum value for sizing a bioretention depends on limitations of the excavation equipment and the topography of the site (Udin,2012).

Table 2-6. Bioretention Criteria for Length and Width (Lucas, 2005).

\begin{tabular}{|c|c|c|}
\hline Source & Length $(\mathbf{m m})$ & Width (mm) \\
\hline Prince George's Co, DER, MD (Clar, et al, 1993) & $>9000-12000$ & $>3000-4500$ \\
\hline Pennsylvania (PACD, 2001) & Same as PGDER & Same as PGDER \\
\hline New York (NYSDEC) & Sized according to Darcy's & \\
\hline US EPA & US EPA & US EPA \\
\hline Vermont (VTDEC) & $>12000$ & \\
\hline Los Angeles, CA & Length: width $=2: 1$ & $4500-7600$ \\
\hline Georgia (ARC, 2001) & Identical to Vermont manual & \\
\hline North Carolina (Hunt \& White) & Sized according to Darcy's \\
law & $>5000$ & $>3000$ \\
\hline Vancouver (GVSDD, 1999) & Surface area < 0.41 ha & \\
\hline Idaho (IDDEQ, 2001) &
\end{tabular}

\subsubsection{Performance of the bioretention facilities}

Infiltration and evapotranspiration are the two major processes occurring in a bioretention facility; these reduce the amount of runoff running on the surface by 50-90\% according to other related factors (Davis et. al, 2012). Two similar watersheds with and without a bioretention facility have been compared by Debusk et al. (2011) and the results showed that the one with a bioretention facility is more reliable and environmentally friendly compared with the conventional stormwater practices for developed areas. 
Hydrologic soil group A and B are more common in the Greater Toronto Area (GTA) and they have higher infiltration rates compared to the other types of soil. A higher infiltration rate is very useful for treating more runoff for each rainfall event (Paquette, 2012). There are some parameters affecting the water quantity performance of the bioretention system like rainfall event patterns as well as the amount of water intercepting. Having an anaerobic zone and using a different type of soil may improve the water quality performance of the bioretention system.

To increase the rate of phosphorous removal, it's recommended to use soil with a small phosphorous index (Davis et al., 2009). Recent laboratory studies stated that the bioretention facilities have a phosphorous removal rate of $60 \%$. Also, field studies on bioretention systems demonstrated that the maximum nitrogen removal rate is $40 \%$ and it differs based on sites and the conditions (Davis et al., 2009) (Paquette, 2012). The removal of suspended solids depends on sedimentation and filtration in the porous media and the usual removal rate is about 70\% (Davis et al., 2009).

For a better understanding of the bioretention facilities and replacing more conventional stormwater management practices, the long-term performance of the bioretention felicities should be studied especially in great cities (Randall,2011). A three-year study of bioretention performance has been done by Chen et al. (2013) and they found that mulch material and more vegetation improved the performance of a biorientation system and the performance removal rate results are very reasonable as described below:

- Removal of TSS $=99 \% \cdot$ Removal of phosphorus between 47\%-68\% Ammonium Removal first test $2.3 \%$, eventually $23 \%$ (Davis, 2008).

The City of Edmonton LID guide stated the overall removal rate in LID facilities in USA and Canada is below (City of Edmonton, 2011):

- Annual Runoff Reduction: 50-90\%

- Total Suspended Solids reduction: 59-90\%

- Metals Removal: 80-90\%

- Total Phosphorus Removal: 5-65\%

- Total Nitrogen Removal: 45-50\% 
The performance of the bioretention facilities is truly based on the location of the site and other site related properties and can be improved by changing some parameters to satisfy the main design objective of each site.

\subsection{Stormwater management models}

For comparing pre- and post-development conditions, stormwater management models or in general water resource computer models play a vital role in providing greater understanding of different conditions (TRCA, 2012). Within TRCA's jurisdiction, some models are suggested for examining hydrology, hydraulics and water balance. Stormwater Hydrology models can be applied to both single events as well as continuous simulation. Event-based modeling or design storm modeling with different return periods like $2,5 \& 10$ - year can focus on calculating flow rates and designing peak reduction. However, continuous modeling uses long-term precipitation events for doing long-term simulation and examination of erosion possibility (TRCA, 2012). Nowadays, there are several urban stormwater management models available in the market both commercially and in the public domain such as Storm Water Drainage System design and analysis program (DRAINS), Urban Drainage and Sewer Model (MOUSE), InfoWorks River Simulation (InfoWork RS), Hydrological Simulation Program-Fortran (HSPF), Distributed Routing Rainfall-Runoff Model (DR3M), Storm Water Management Model (SWMM), XP Storm Water Management Model (XPSWMM), MIKE-SWMM, Quality-Quantity Simulators (QQS), Storage, Treatment, Overflow, Runoff Model (STORM), and Hydrologic Engineering Centre-Hydrologic Modelling System (HEC-HMS) (Haris et al., 2016).

The most popular model is EPA Storm Water Management Model or in brief SWMM. The first version of SWMM was introduced in 1971 and the last version SWMM 5.1.012 released in March 2017. The EPA Storm Water Management Model (SWMM) is a dynamic rainfall-runoff simulation model for both single events and continuous modeling of stormwater quantity and quality mainly in urban areas (Rossman, 2008). For modeling, non-point pollution sources and the transport of pollutants several studies have been done. Also, SWMM has been used for simulating LID and some problems have occurred. McCutcheon and Wride (2013) stated that LID parameters for a single event and long-term parameters were different in SWMM and there's a gap between their field observations and model results. The moisture conditions before a storm may affect LID 
infiltration capacity and during single events (Design storm) it is easier to fix clogging or debris. In brief, SWMM has these capacities (USEPA,2017):

- Time-varying rainfall

- Evaporation of standing surface water

- Snow accumulation and melting

- Rainfall interception from depression storage

- Infiltration of rainfall into unsaturated soil layers

- Percolation of infiltrated water into groundwater layers

- Interflow between groundwater and the drainage system

- Nonlinear reservoir routing of overland flow

- Runoff reduction via LID controls

According to the main research question and the objective of this thesis, EPA SWMM has been selected for use as the modeling of this study and with PCSWMM from CHI Water has been used since it has the better graphical interface as well as some extra features. SWMM has some limitations and for the last part of this study, we have developed a finite element model (FLOW 3D) for the movement of water inside the perforated pipe on top of the bioretention system in order to have a better water distribution over the bioretention cell. In the following chapter, the methodology and modeling procedure of this research will be explained precisely. Figure 2-11 displays SWMM5's process models and their procedures.

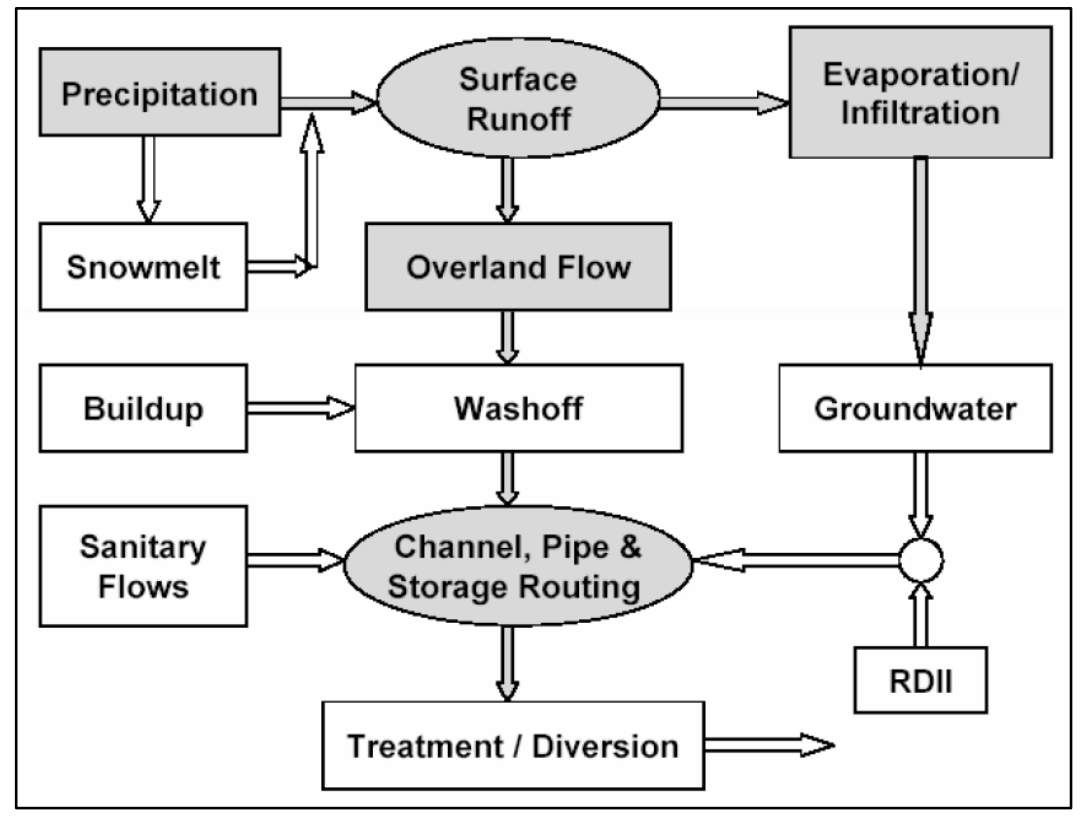

Figure 2-11: SWMM5's Process Models (Huber, 2012). 


\section{Chapter 3 Methodology}

\subsection{Introduction}

In this chapter, the modeling a bioretention facility is described using the different approaches. First, we focused on the inlet and outlet hydrographs with the various inlet configurations and then the performance of the bioretention was investigated. A typical right-of-way (roadside) bioretention facility has these components: 1) Inlet (such as catch basin). 2) Perforated distribution pipe on the top of the bioretention cell. 3) A bioretention cell with the surface, soil, and storage layer. 4) Flow control pipe (underdrain pipe). 5) Manhole for returning water back to the sewers system. Before explaining the procedure, some basic definitions are discussed in the following subchapters.

\subsection{Rainfall Intensity}

The ratio of the total amount of rain (rainfall depth) falling during a period of time is described as rainfall intensity and it is specified in-depth units per unit time, typically as $\mathrm{mm}$ per hour ( $\mathrm{mm} / \mathrm{h})$. Studies showed that the statistical characteristics of high-intensity, short-duration, convective rainfall do not deoend on their locations within a region and most of them are the same around the world (FAO, 1991).

Knowing the exact amount of rainfall intensity is crucial for calculating runoff as input to a bioretention facility. It can be obtained either from installed rain gauges near a bioretention facility or the local Intensity Duration Frequency (IDF) curves. IDF curves are developed from rainfall records collected over a period of years (MTO, 1997). The local rainfall Intensity Duration Frequency (IDF) curve can be used for the design of municipal water management infrastructures such as sewer, stormwater management ponds \& etc. The case study (Queensway Bioretention System of Sustainable Sidewalk) of this research is in Etobicoke, Toronto. So, we need to consider the IDF curve for the city of Toronto. Figure 3-1 shows the IDF curve for the city of Toronto up to 2010 . 


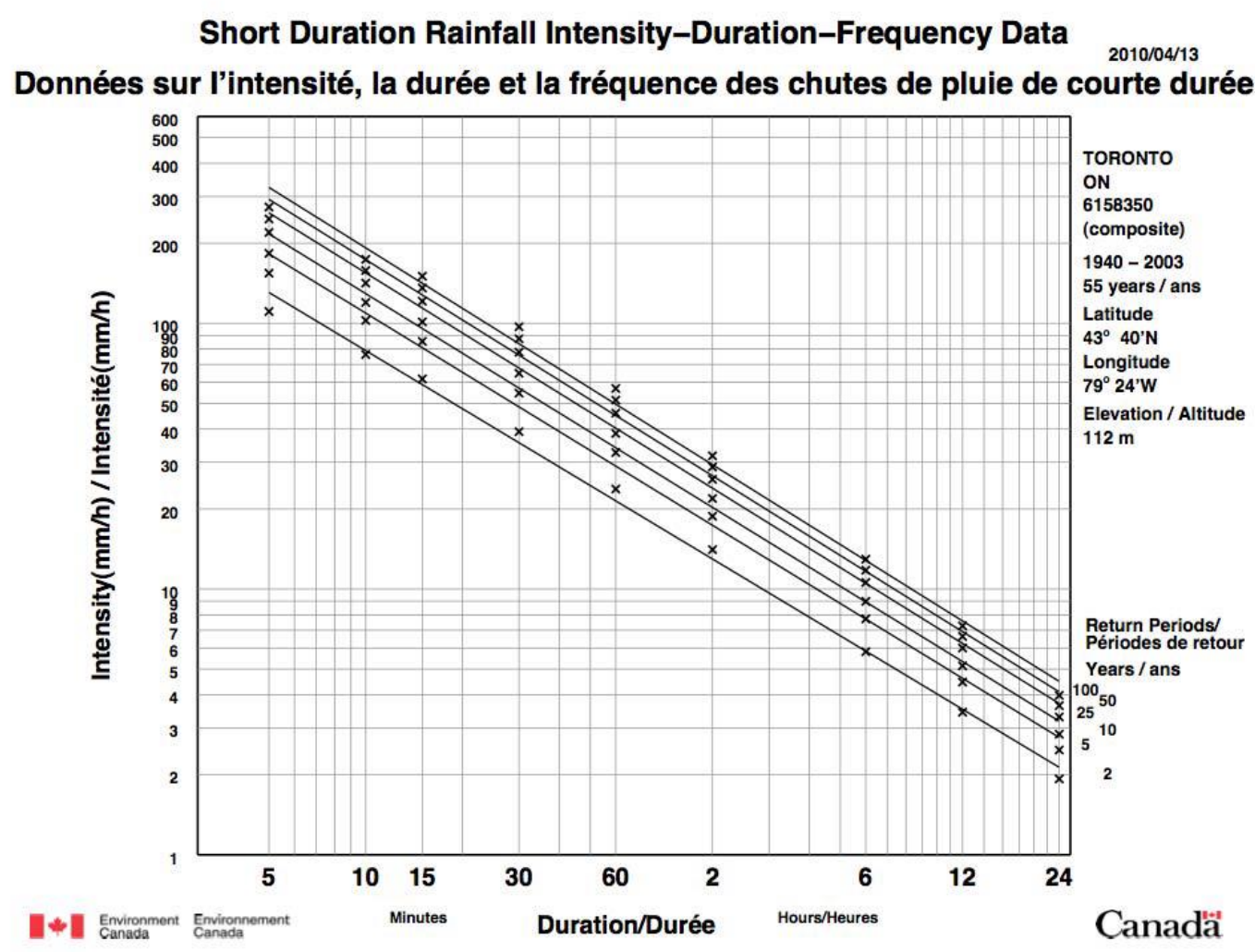

Figure 3-1: IDF curve for the city of Toronto ((http://climate.weatheroffice.gc.ca).

IDF curves can be showed in numerical form in equation 3-1 (MTO, 1997):

$$
i=\frac{A}{\left(t_{d}+B\right)^{c}}
$$

where:

$\mathrm{i}=$ average rainfall intensity, $\mathrm{mm} / \mathrm{h}$.

$\mathrm{t}_{\mathrm{d}}=$ rainfall duration, min.

$\mathrm{A}, \mathrm{B}$, and $\mathrm{c}$ are coefficients depending on the location and the frequency which is different for each location.

Taking $\log$ from both sides of the equation 3-1 forms equation 3-2:

$\log \mathrm{i}=\log \mathrm{A}-\mathrm{c} \log \left(\mathrm{t}_{\mathrm{d}}+\mathrm{B}\right)$

This equation is a straight line, $\mathrm{c}$ is the slope of the line and the least squares statistical method can be used for solving this equation. Also, the coefficient B must be determined by trial and error method (MTO, 1997). The Chicago design storm is selected for this research for different return periods $(2,5,10,25 \& 100$-year). The hyetographs can be created for Chicago design storms for a 
specific location by having $\mathrm{A}, \mathrm{B}, \mathrm{C}$, time intervals and the duration of the storm and will be discussed in the next chapter.

The bioretention facility at Queensway Avenue in the City of Toronto was designed by the Silva Cell Inc (technology provider). In Toronto, a normal rain event is $2-3 \mathrm{~mm}(0.09-0.12$ ”) in 24 hours. The purpose of this design was to capture a typical rainfall event in Toronto of $25 \mathrm{~mm}$ in 24 hours since $50 \%$ of Toronto's annual rainfall events are less than $5 \mathrm{~mm}(0.19 \mathrm{inch})$ (www.deeproot.com). Since the design goal is only based on the volumetric design which is $25 \mathrm{~mm}$ in 24 hours, we need to consider other comprehensive design goals such as peak flow and volume reduction and more detention time to fill this design gap for finding better design recommendations.

\subsection{Runoff}

The Rational method is the most common way to calculate the peak runoff in a specific drainage area. This peak runoff uses as a design discharge for the design of sewer systems in the urban areas. Equation 3-3 demonstrates the general equation for the Rational method (Thompson, 2006): $Q=C_{u} C i A$

Where:

$\mathrm{Q}=$ design discharge $\left(\mathrm{L}^{3} / \mathrm{T}\right)$,

$\mathrm{C}_{\mathrm{u}}=$ units conversion coefficient,

$\mathrm{C}=$ runoff coefficient (dimensionless),

$\mathrm{i}=$ design rainfall intensity $(\mathrm{L} / \mathrm{T})$, and

$A=$ watershed drainage area $\left(\mathrm{L}^{2}\right)$.

The SI form of equation 3-3 becomes equation 3-4:

$Q_{p}=\frac{1}{360}$ C.i.A

Where:

$\mathrm{Q}_{\mathrm{p}}=$ the runoff quantity, $\mathrm{m}^{3} / \mathrm{s} ; \mathrm{A}=$ drainage area, ha; $\mathrm{i}=$ average rainfall intensity, $\mathrm{mm} / \mathrm{hr} ; \mathrm{C}=$ runoff coefficient.

The runoff coefficient, $\mathrm{C}$, is a dimensionless ratio that equals total depth of runoff divided by total depth of precipitation (Thompson, 2006):

$C=\frac{R}{P}$ 
Table 3-1 shows general runoff coefficients for the Rational method:

Table 3-1: General runoff coefficients for the rational method (Thompson, 2006).

\begin{tabular}{|c|c|}
\hline Description & Runoff Coefficient \\
\hline \multicolumn{2}{|c|}{ Business } \\
\hline Downtown Areas & $0.70-0.95$ \\
\hline Neighborhood Areas & $0.50-0.70$ \\
\hline \multicolumn{2}{|c|}{ Residential } \\
\hline Single-family & $0.30-0.50$ \\
\hline Multi-family detached & $0.40-0.60$ \\
\hline Multi-family attached & $0.60-0.75$ \\
\hline Residential suburban & $0.25-0.40$ \\
\hline Apartments & $0.50-0.70$ \\
\hline Parks, cemetaries & $0.10-0.25$ \\
\hline Playgrounds & $0.20-0.35$ \\
\hline Railroad yards & $0.20-0.40$ \\
\hline Unimproved areas & $0.10-0.30$ \\
\hline Drives and walks & $0.75-0.85$ \\
\hline Roofs & $0.75-0.95$ \\
\hline \multicolumn{2}{|c|}{ Streets } \\
\hline Asphalt & $0.70-0.95$ \\
\hline Concrete & $0.80-0.95$ \\
\hline Brick & $0.70-0.85$ \\
\hline \multicolumn{2}{|c|}{ Lawns; sandy soils } \\
\hline Flat, $2 \%$ slopes & $0.05-0.10$ \\
\hline Average, $2 \%-7 \%$ slopes & $0.10-0.15$ \\
\hline Steep, $7 \%$ slopes & $0.15-0.20$ \\
\hline \multicolumn{2}{|c|}{ Lawns; heavy soils } \\
\hline Flat, $2 \%$ slopes & $0.13-0.17$ \\
\hline Average, $2 \%-7 \%$ slopes & $0.18-0.22$ \\
\hline Steep, $7 \%$ slopes & $0.25-0.35$ \\
\hline
\end{tabular}

We have used SWMM as a primary tool for performing this research. The way SWMM calculates surface runoff is different from the Rational method. Figure 3-2 demonstrates a conceptual view of surface runoff used by SWMM5. Each subcatchment surface is considered as non- linear reservoir. Precipitation and any upstream flows as inflows and infiltration, evaporation, and surface runoff reflect outflows. The maximum depression storage equals the capacity of this reservoir and ponding, surface wetting, and interception cause formation of the maximum surface storage (Rossman, 2008).

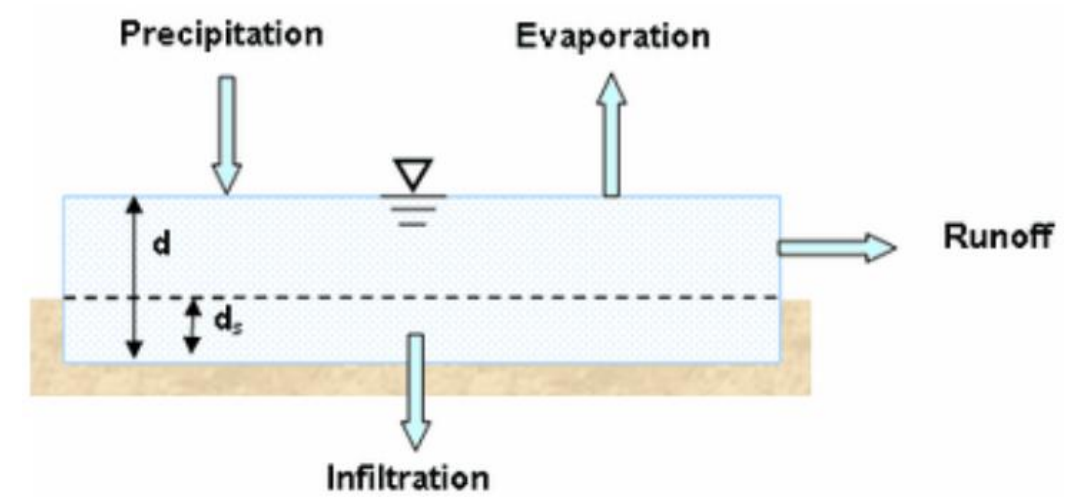

Figure 3-2: Conceptual view of surface runoff (Rossman, 2008). 
In SWMM, when the depth of water (d) in this reservoir is more than maximum depression storage, surface runoff per unit area (q) happens. The outflow is calculated by Manning's equation. Water over the subcatchment (d) changes continuously during a period by considering a water balance equation over the subcatchment. Therefore, equation (3-6) \& (3-7) give us surface runoff and surface runoff per unit area subsequently:

$Q=\frac{1.00}{n} W\left(d-d_{s}\right)^{5 / 3} S^{1 / 2}$

$q=\frac{1.00 W s^{1 / 2}}{A n}\left(d-d_{s}\right)^{5 / 3}$

Where:

$$
\begin{aligned}
\mathrm{Q} & =\text { runoff volumetric flow rate } \\
\mathrm{q} & =\text { surface runoff per unit of surface area } \\
\mathrm{n} & =\text { Manning's surface roughness coefficient for overland flow } \\
\mathrm{W} & =\text { subcatchment width } \\
\mathrm{d} & =\text { depth of water over the subcatchment } \\
\mathrm{d}_{\mathrm{s}} & =\text { depression storage depth } \\
\mathrm{S} & =\text { average slope of the subcatchment } \\
\mathrm{A} & =\text { surface area of subcatchment }
\end{aligned}
$$

\subsection{Right-of-way (roadside) bioretention facilities}

If a bioretention facility is constructed near or at the side of a road, it can be categorized under the right-of-way (roadside) bioretention facilities and has two different types:

- Conventional bioretention with a surface layer

In this type of bioretention, stormwater runoff generates from a section of the street (catchment area) and is captured by the one inlet or multiple inlets. Inlets are typically in the form of the curb cut and the number of inlets and the location of inlets depend on the length of the bioretention cell and other project characteristics. Seized runoff starts to pond at the surface layer and then infiltrates into the bioretention cell. Also, there's an overflow pipe on the surface layer for conveying excess overflow runoff. After the treatment by the 
bioretention cell, runoff can go either to native soil or an underdrain pipe or a combination of the two methods and returns to the sewer system (Prince George's County, 2009).

- Underground bioretention without a surface layer

The procedure is exactly the same as in conventional bioretention. This type doesn't have a surface layer and ponding water on the surface instead has the perforated pipe on the top of the bioretention cell for uniform water distribution. The inlet or inlets can be in the form of a grate inlet (catch basin), curb opening and a combination of both. Intercepted runoff is based on the inlet efficiency and excess runoff bypasses along the street. This type of bioretention is a useful LID solution for highly urbanized areas since it can be constructed under the sidewalk of the road and doesn't need a huge area for construction.

\subsubsection{Runoff generation}

As mentioned before, runoff generates in the section of a street as a catchment area by longitudinal and transverse slopes and only a portion of the runoff seized by the catch basin. The captured runoff is the inflow to the bioretention facility depending on the efficiency of the grate $(\mathrm{E})$. The efficiency of the grate (E) specifies the amount of runoff that can bypass through the inlet since the minor systems are typically designed only for 2-year events. Most of the runoff is captured by the inlet in the case of a low intensity and short duration rainfall event. The efficiency of a grate inlet considers both frontal and side flow. Equation (3-8) shows the amount of frontal flow which is part of the total gutter flow (USFHWA, 2013):

$Q_{w}=Q\left[1-(1-\mathrm{w} / \mathrm{T})^{2.67}\right]$

Where, $Q_{w}$ is frontal flow, $Q$ is the total discharge flow in the gutter, $w$ width of the inlet, $T$ is allowable spread of water in the gutter. For side flow, the flow is equal to (USFHWA, 2013): $Q_{s}=Q-Q_{w}$

Where, $Q_{s}$ is side discharge equivalent to the flow outside the width of the inlet (T-W). The ratio of frontal captured flow to total flow $\left(R_{f}\right)$ is shown in equation (3-10) (USFHWA, 2013):

$R f=Q_{w i} / Q_{w}=1.0-K f\left(V-V_{o}\right)$ 
For $V>V_{o}$ and $R f=1.0$ and for $V \leq V_{o}$, where $K_{f}$ is conversion ( $0.295 \mathrm{~s} / \mathrm{m}$ in metric unit), $Q w i$ is frontal flow intercepted, $V$ is average velocity of flow in the gutter, and $V_{o}$ is splash over velocity. Figure 3-3 shows splash over velocity vs grate inlet length for different grate inlets:

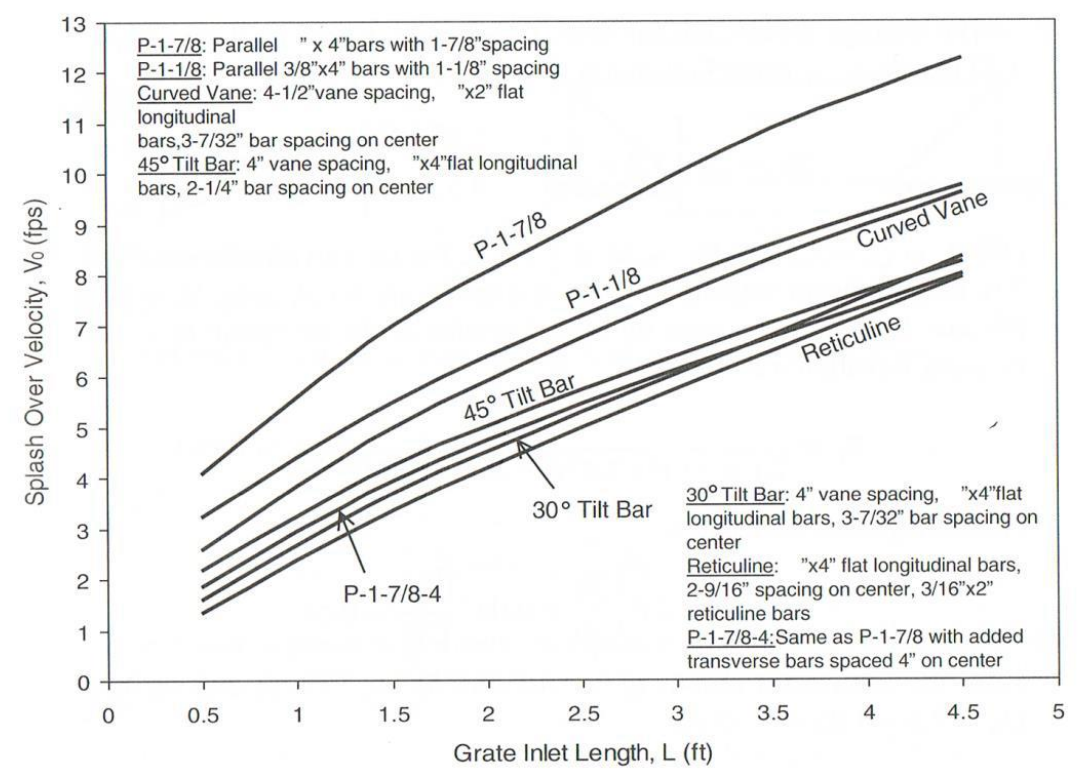

Figure 3-3: Splash over velocity (USFHWA, 2013).

Also, the captured side flow to total side flow ratio $(R s)$ is stated as (USFHWA, 2013):

$R_{S}=\frac{Q_{S i}}{Q_{S}}=\frac{1}{1+\left[\frac{K_{S} V^{1.8}}{S_{x} l^{2.3}}\right]}$

where, $Q s i$ is side flow intercepted, $S x$ is cross slope, $K s$ is conversion factor $(0.0828$ for metric unit), and 1 is length of grate. So, the inlet efficiency is shown in equation (3-12):

$$
E=R_{f} \frac{Q_{w}}{Q}+R_{s} \frac{Q_{s}}{Q}
$$

The second term is negligible with high velocities and short grates (USFHWA, 2013). By having grate efficiency and equation (3-4), the actual runoff captured by the bioretention facility can be calculated by:

$Q_{p}=\frac{1}{360} C \cdot i . A . E$

Where $\mathrm{Q}_{p}$ is the peak surface runoff rate $(\mathrm{m} 3 / \mathrm{s}), \mathrm{C}$ is the runoff coefficient $(0.70-0.95$ for paved areas) (Thompson, 2006), $\mathrm{i}=$ Rainfall intensity ( $\mathrm{mm} / \mathrm{hr}$ ) and $\mathrm{A}=$ catchment area (ha). 


\subsubsection{Inlet}

In this research, the inlets are in the form of catch basins, curb cuts and curb openings. As mentioned before, the case study of this project is in the city of Toronto. In the Queensway project, the inlet is a dual catch basin (OPSD (Ontario Provincial Standard Drawing) 400.07). For research purposes, four different catch basins: 1- Single \& twin horizontal bar/fishbone catch basin 2Single \& twin grid catch basin 3- Single \& twin honeycomb catch basin 4- Single OPSD 400.01 from the City of Toronto, curb cut, and curb opening were investigated. The data for the OPSD 400.07 were insufficient since the MTO drainage manual was published in 1997. Therefore, the OPSD 400.01 is used instead of OPSD 400.07.

\subsubsection{Rating curve}

A curve that represents the relationship between discharge and depth or head of water in a given spot such as a catch basin is also known as an inlet capacity curve. For modeling dual drainage systems in SWMM, inlet capacity curves can be used to model catch basins between the major and minor systems (streets and storm sewers) (Rossman, 2008). The amount of captured and bypass runoff can be determined by the inlet capacity curves. Figure 3-4 shows inlet capacity curves that were used in this research:

\section{Inlet Capacity Curves}

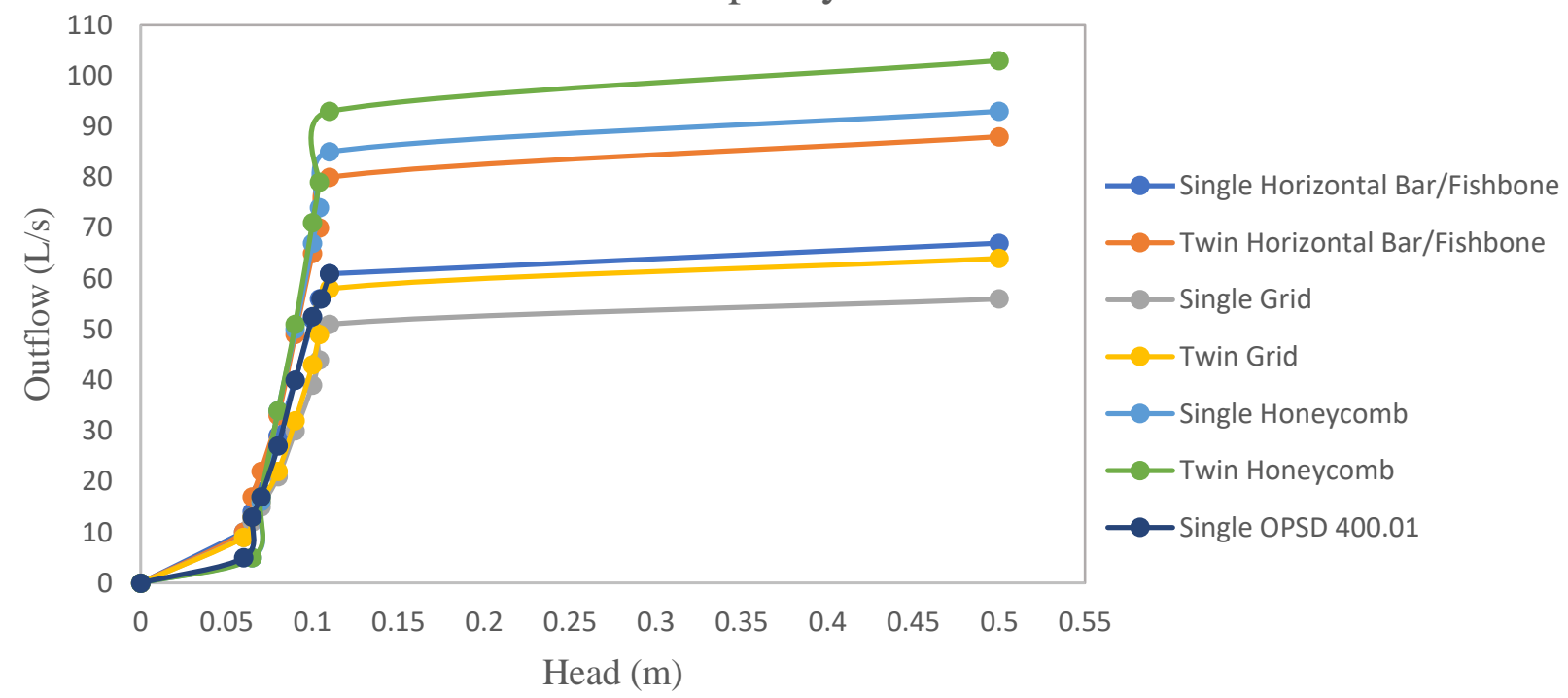

Figure 3-4: Inlet capacity curves for different catch basins (City of Toronto, 2014) (MTO, 1997).

The profile slope of the single $\&$ twin horizontal bar/fishbone, grid and honeycomb catch basins is an average slope (0.5-3.99\%) and the cross slope for OPSD 400.01 is $\mathrm{S}_{\mathrm{x}}=0.02$. For both inlet 
efficiency (E) and inlet capacity curves, a clogging factor must be taken into account. Figure 3-5 demonstrates OPSD 400.07 catch basin during and after the rainfall event in the City of Toronto in November 2017 and the importance of the clogging factor for the catch basins.

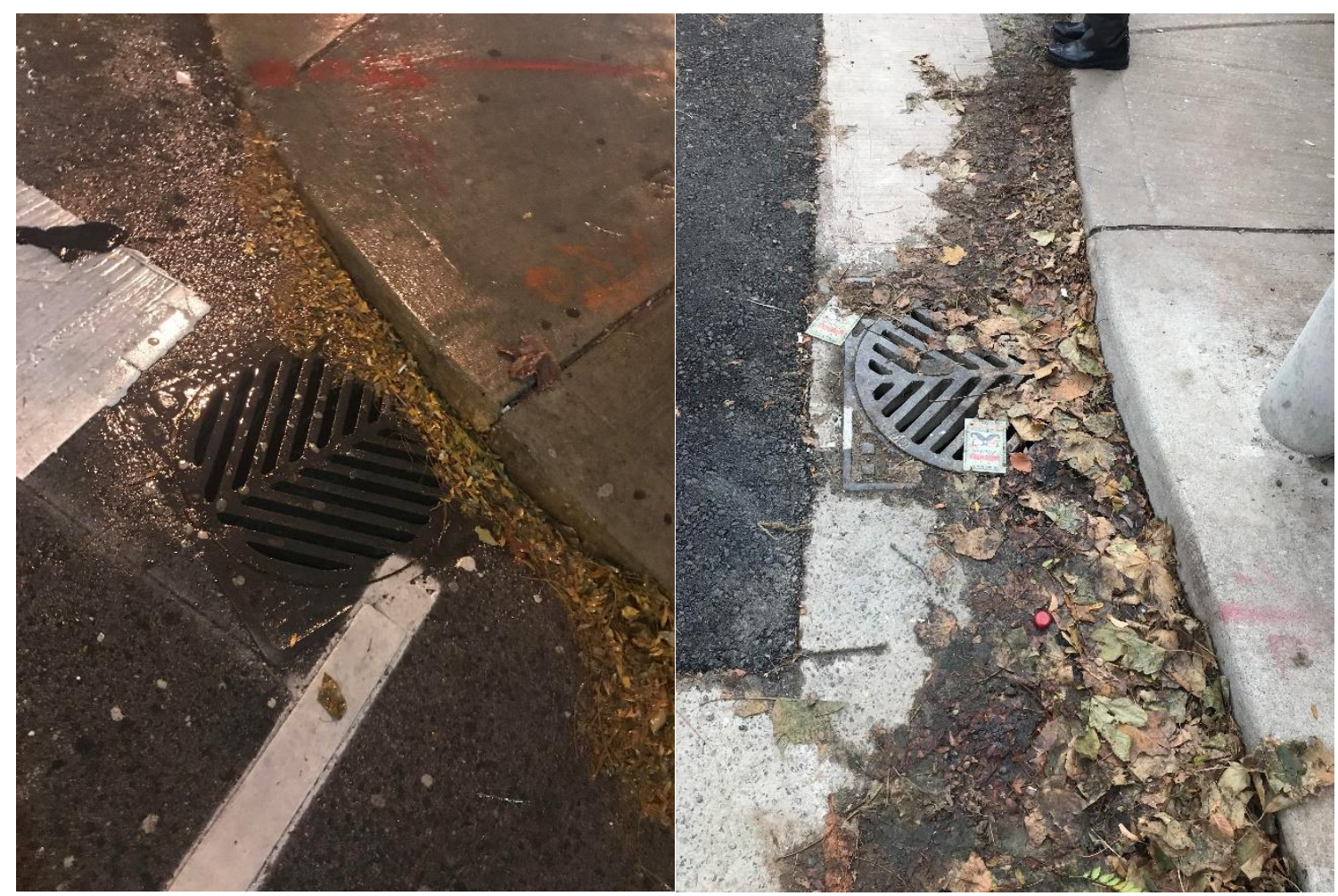

Figure 3-5: OPSD 400.07 catch basin during and after the rainfall event in the City of Toronto in November 2017.

\subsubsection{Curb opening \& Curb cut}

The curb opening is studied as one of the hypothetical inlets with a 0.5 -meter opening. Instead of rating curves, the curb opening is considered as a side flow weir with the rectangular cross section. Flow rate through a side flow weir can be calculated by (Rossman, 2008):

$Q=C_{W} L h^{5 / 3}$

Where: $\mathrm{C}_{\mathrm{W}}$ weir discharge coefficient, $\mathrm{L}$ weir length, $\mathrm{h}$ head difference across the weir.

Weir discharge coefficient for rectangular weirs is between 1.38-1.83 for the SI units and 1.5 is used for this research (Rossman, 2008).

In addition, the curb cut also is investigated as another hypothetical inlet with a 0.5 -meter opening. A curb cut considered as a side orifice and flow rate through a side orifice can be calculated by (Rossman, 2008): 
$Q=C A \sqrt{2 g h}$

Where: C discharge coefficient, A area of orifice opening, g acceleration of gravity, h head difference across the orifice. Orifice discharge coefficient for side orifices is between 0.4870.631 and 0.62 is selected for this research (Rossman, 2008).

\subsubsection{Distribution pipe}

In the underground bioretention, a distribution pipe must be used on the top of the bioretention cell in order to have a uniform distribution of water over the cell. The distribution pipe can be in the form of a corrugated perforated pipe or a normal PVC pipe with a set drilled perforation on it. The number of perforations and the distance between perforations depends on each project and it's different for each project (www.deeproot.com). The flow rate is calculated by equation (3-15) where A is the total area of all orifices in a cross-section. It's recommended that the perforations not to put on the bottom of the pipe since runoff does not reach to the end of the pipe and distribution of the flow is not uniform. In that way, the stormwater runoff will distribute uniformly along the pipe after a head of water accumulates at the bottom of the pipe (Udin, 2012). An example of perforation alignment of the perforated pipe shown below in Figure 3-6.

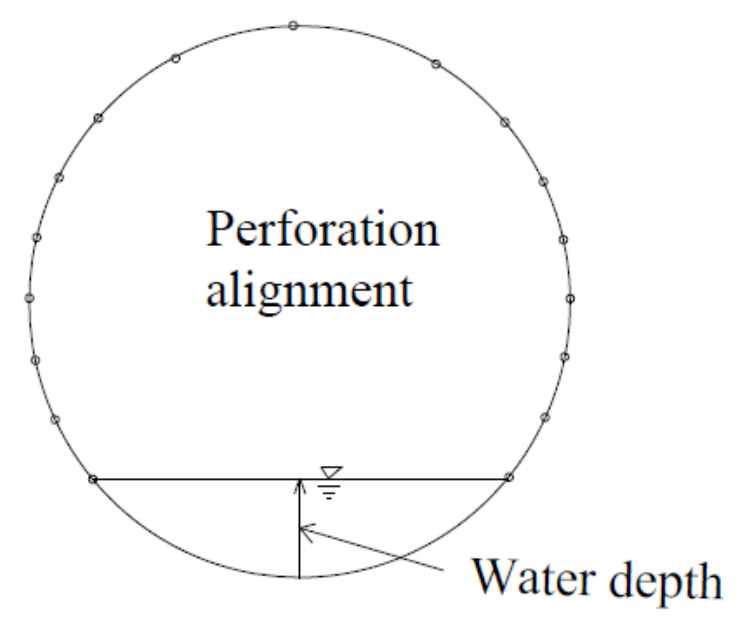

Figure 3-6: An example of perforation alignment of the perforated Pipe (Udin, 2012).

\subsubsection{Bioretention cell}

SWMM can model a bioretention cell with the LID module. A conventional bioretention cell has surface depressions with vegetation grown in an engineered soil mixture placed above a gravel 
drainage bed. Recent studies show that loamy sand or sandy loam is the optimal soil mixture for bioretention cells. Infiltration, storage, and evaporation are the three main processes happening in a bioretention cell because of direct rainfall and seized runoff from surrounding areas. The LID module in SWMM considers a bioretention cell only vertically in one direction in three different layers and applies the Green \& Ampt method for infiltration modeling. Figure 3-7 demonstrates flow equations in a bioretention cell in the surface, soil, and storage layer. The first equation follows the depth of water on the surface layer, the second one refers to the moisture content in the soil layer and the third one considers the depth of stored water in the storage layer (Rossman, 2008).

Where: $\mathrm{d}=$ water depth, $\mathrm{q}=$ flow rate, $\mathrm{e}=$ evapotranspiration, $\mathrm{f}=$ infiltration or soil percolation, $\mathrm{q}=$ moisture content $\mathrm{f}=$ void ratio, and $\mathrm{t}=$ time .

$$
\begin{gathered}
\frac{\partial d_{1}}{\partial t}=q_{0}-e_{1}-f_{1}-q_{1} \\
D_{2} \frac{\partial \theta}{\partial t}=f_{1}-e_{2}-f_{p} \\
\phi \frac{\partial d_{3}}{\partial t}=f_{p}-e_{3}-f_{3}-q_{3}
\end{gathered}
$$

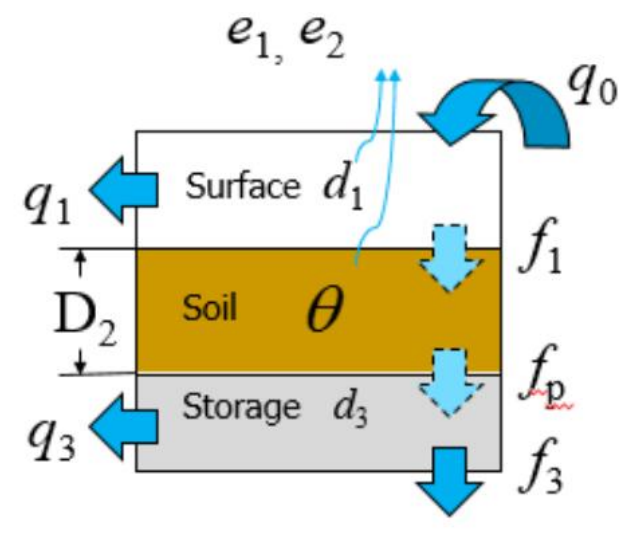

Figure 3-7: A conceptual view of a bioretention cell and flow equations (Rossman, 2008).

\subsubsection{Underdrain pipe}

A LID underdrain is considered as an orifice (drain exponent $=0.5$ ), equation (3-16) shows the drain flow through the underdrain (Rossman, 2008):

$Q_{L I D}=C_{L I D} A_{L I D} \sqrt{h}$

Where

$$
\begin{aligned}
\mathrm{Q}_{\mathrm{LD}} & =\text { drain flow (in/hr) } \\
\mathrm{C}_{\mathrm{LD}} & =\text { drain coefficient } \\
\mathrm{h} & =\text { driving head (ft) }
\end{aligned}
$$


$\mathrm{A}_{\mathrm{LID}}=$ footprint area of all LID replicate units $\left(\mathrm{ft}^{2}\right)$

By converting QLID from in/hr to feet/s and considering orifice equation in US units:

$Q_{\text {orif }}=C_{d} A_{\text {orif }} \sqrt{\frac{2 g h}{12}}$

LID drain coefficient in US units is equal to:

$$
C_{L I D}=43200 \sqrt{\frac{g}{6}} C_{d} \frac{A_{\text {orif }}}{A_{L I D}}
$$

And for the SI units equals (Rossman, 2008):

$C_{L I D}=160997 \sqrt{g} C_{d} \frac{A_{\text {orif }}}{A_{L I D}}$

Where:

$$
\begin{aligned}
\mathrm{g} & =\text { gravitational constant, } 9.8 \mathrm{~m} / \mathrm{s}^{2} \\
\mathrm{C}_{\mathrm{d}} & =\begin{array}{l}
\text { orifice coefficient of discharge, typically in the range of } 0.6-0.65 \\
\text { (unitless) }
\end{array} \\
\mathrm{A}_{\text {orif }} & =\text { cross-sectional flow area, } \mathrm{m}^{2} \\
\mathrm{~A}_{\mathrm{LID}} & =\text { footprint area of all LID replicate units }\left(\mathrm{m}^{2}\right)
\end{aligned}
$$

\subsection{Modeling Approach}

EPA SWMM was used as the main approach in this research for modeling a bioretention facility and FLOW-3D as a refinement method was applied for optimizing \& improving the results of the SWMM model. A SWMM model was developed for the entire system for modeling the major, minor system \& bioretention facility, and a finite element model (FLOW-3D) also established for modeling the distribution pipe for scenarios where underground bioretention was used. For integrating FLOW-3D results with SWMM model, the performance of the bioretention facility was investigated again with the new design and size reduced by the reduction curve and the effective length of the bioretention cell or how much of the bioretention cell utilized -and the results will be compared with the previous design. 


\subsubsection{SWMM approach}

A SWMM model was developed with the help of PCSWMM software. The dual drainage modeling (major \& minor system) was used to model a section of a street and the bioretention facility. The catchment area is a section of the street and is considered as the main subcatchment (S1-Road) and the bioretention is a small subcatchment (Bioretention-Loamy sand) with 100\% LID. Each subcatchment in SWMM must be assigned with a rain gage. The rain gage of S1-Road is the different design storms $(2,5,10 \ldots$-year, continues simulation) and for the bioretention in the case of underground bioretention is a null rain gage ( 0 rainfall intensity) since it doesn't have a surface layer. For conventional bioretention, the rain gage of both subcatchment must be the same because the conventional bioretention also receives direct rainfall on its surface level. A dummy node (MJ1-Dummy) was defined as an outlet of the S1-Road subcatchment. For the major system(street), Major 1,2 \& 3 are the sections of the street (half of the street) with the irregular cross-section created with dual drainage creator tool in PCSWMM. The length of the Major 1 is $74.552 \mathrm{~m}$, which is the longest flow path before runoff is captured by the inlet. The length of the Major $2 \& 3$ is $70 \mathrm{~m}$. OF3 Downstream is the outfall at the end of the major system. Outlets represent inlets in SWMM and the outlet was defined between MJ2 and OF1. The inlet capacity curves can be applied by the outlet in catch basin scenarios. As mentioned before, a side flow weir for the curb opening scenarios and a side orifice for the curb cut scenarios were used. On the other hand, the minor system (sewers system) has two nodes (M1, M2), two circular conduits with a 0.5 $\mathrm{m}$ diameter, and an outfall (OF2) at the downstream. A dummy node (Dummynode) also was defined for the bioretention subcatchment for underground bioretention scenarios. This dummy node was used for capturing any surface runoff since in SWMM the actual surface layer is $0.001 \mathrm{~m}$ instead of 0 for the nature of computation in the software.

The process starts with the calculation of surface runoff per unit of surface area by SWMM regarding the subcatchment area, slope, and runtime (24 hours). Stormwater runoff is sent to the outlet node (DUMMY1) and conveyed to MAJOR1 by the section of the street (STREET). At MAJOR1, hydrographs of captured runoff by inlet and the bypass runoff can be determined. The captured runoff in CATCHBASIN is sent to the BIORETENTION subcatchment by the "Route To" command in SWMM. After infiltration by the bioretention cell into soil layer and hypothetical storage layer, runoff drains to the UNDERDRAIN node (beginning of the minor system) by the 
"Send drain flow to" command in SWMM. The Outflow hydrograph can be found at UNDERDRAIN node and released runoff from bioretention returns to the sewers network and eventually to the outfall (MINOR). Figure 3-8 exhibits the dual drainage (Major, Minor, and bioretention cell) model in SWMM and Figure 3-9 shows Flow pathways through the bioretention system.
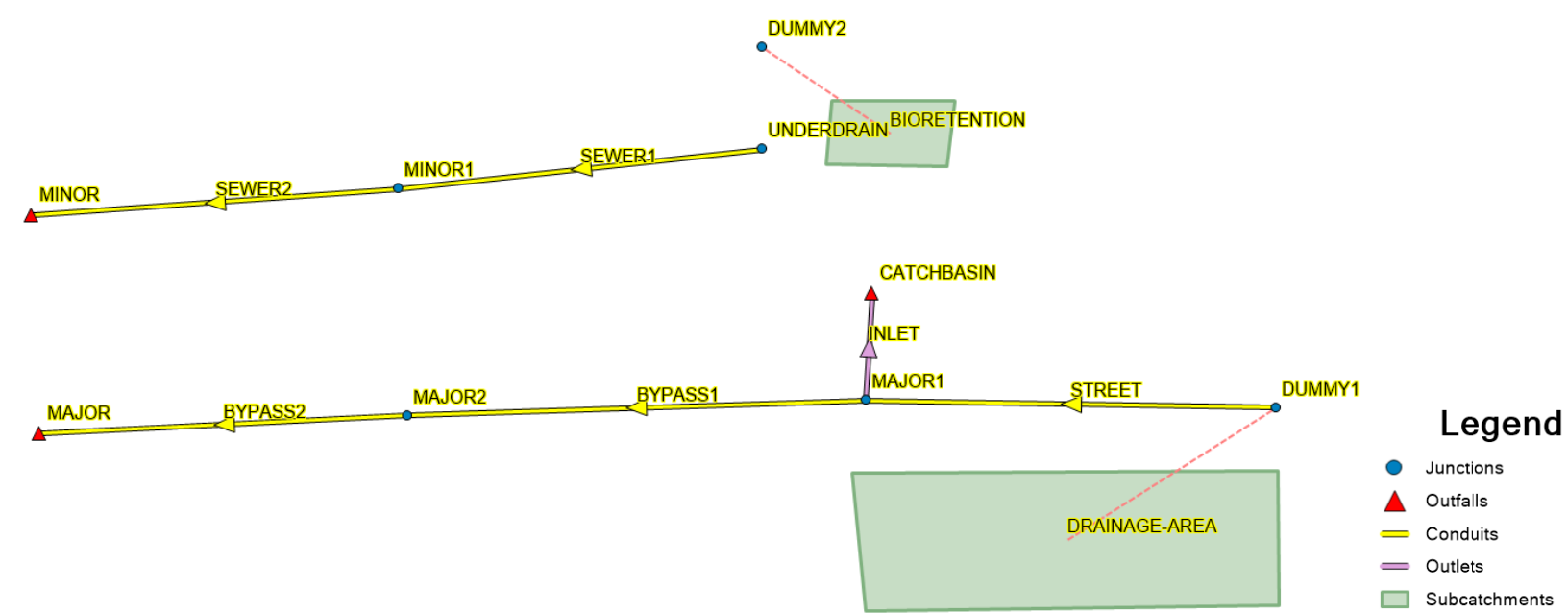

Figure 3-8: Dual drainage modeling in SWMM.

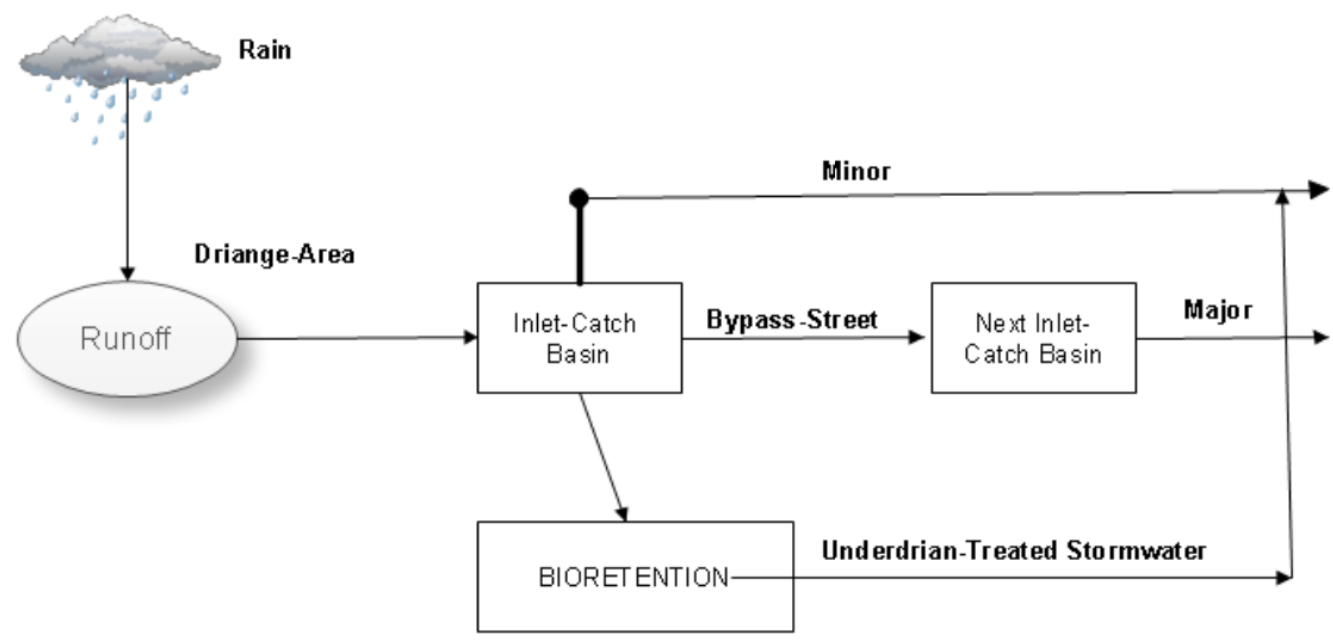

Figure 3-9: Flow pathways through the bioretention system.

The characteristics of subcatchments, nodes, conduits, and outlets will be discussed in the results and discussion chapter.

\subsubsection{Flow-3D refinement method}

A finite element model was developed with the help of FLOW-3D software. Two scenarios were investigated by FLOW-3D: 1- 6 inches (150mm inner diameter) perforated pipe with a length of 
$6.5 \mathrm{~m}, 4$ perforations at the bottom of the pipe with the size of $25 \mathrm{~mm} \times 2.5 \mathrm{~mm}$ for each perforation and a distance of $1.5 \mathrm{~m}(1.5 \mathrm{~m}, 3 \mathrm{~m}, 4.5 \mathrm{~m}, 6 \mathrm{~m})$ between each perforation as an initial model and for simplicity of the modeling. 2- 6 inches (150mm inner diameter) perforated pipe with a length of $18 \mathrm{~m}$, the diameter of the perforations is $10 \mathrm{~mm}$, the distance between perforations along the pipe is $0.9 \mathrm{~m}, 4$ perforations on the cross-section of the pipe with the $45^{\circ}$ angle (total number of the perforation is 76).

Comparing the experimental data (water level \& water profile) inside the perforated pipe with the simulation data is the main purpose of this approach. In addition, determining the percentage of the perforated pipe that was utilized especially in the lower flows in Flow-3D was another purpose of this approach. The water profiles under different captured flow rates from inlet hydrographs (between 2 to 10 1/s) can be plotted. Also, the percentage of utilization of the bioretention can be calculated by plotting different flow rates vs the percentage of bioretention length that was utilized during the simulation by finding the effective length of the bioretention cell. A reduction scale factor of the perforated pipe can be found by comparing the inlet hydrograph with the percentage of the perforated pipe that was utilized. Reduction scale factor can reduce the size of the bioretention cell and change the design of the bioretention facility. Figure 3-10 shows the first scenario (perforated pipe with 4 four perforations) in $\mathrm{x}, \mathrm{Z}$-direction.

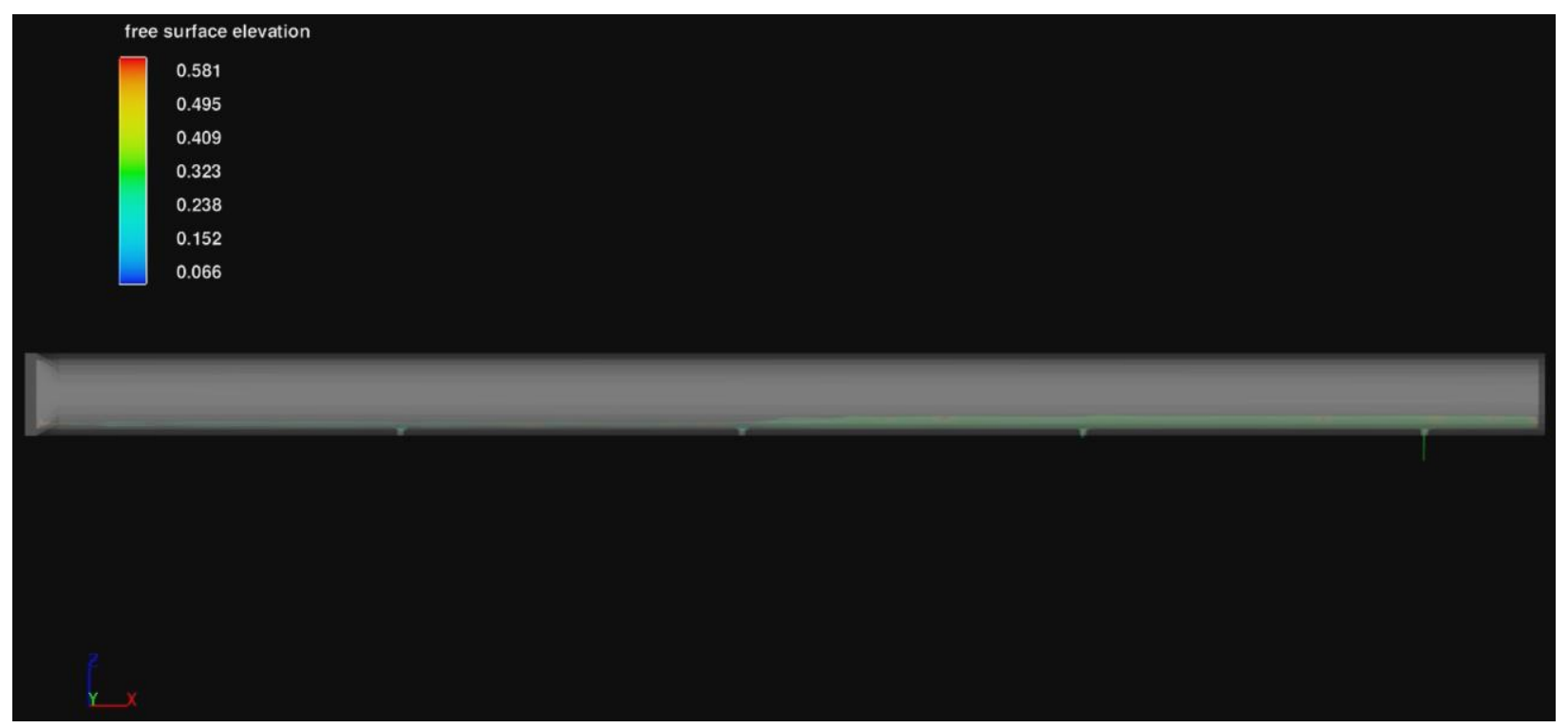

Figure 3-10: First Scenario in Flow-3D software in $\mathrm{x}, \mathrm{z}$ direction. 


\subsubsection{Introduction to Flow-3D}

Flow-3D is a comprehensive modeling tool that can solve many fluid flow problems. The aerospace industry, several forms of casting, and different aspects of hydro-electric generating stations are the applications of this software. Flow-3D has serval meshing and geometry options including multi-block grids. Simple shapes can be drawn, and more complicated geometry objects or topographic files should be imported to the software. Depending on a model, different boundary conditions can be applied for a particular application. Also, Flow-3D has various implicit and explicit numerical solver options (Chanel, 2008).

The Navier-Stokes equations in three dimensions can be solved by Flow-3D to imitate the fluid flow equations together with the continuity shown below in Equation 3-20:

$$
\underbrace{\rho\left(\frac{\partial \mathbf{u}}{\partial t}+\mathbf{u} \cdot \nabla \mathbf{u}\right)}_{1}=\underbrace{-\nabla p}_{2}+\underbrace{\nabla \cdot\left(\mu\left(\nabla \mathbf{u}+(\nabla \mathbf{u})^{T}\right)-\frac{2}{3} \mu(\nabla \cdot \mathbf{u}) \mathbf{I}\right)}_{3}+\underbrace{\mathbf{F}}_{4}
$$

Where $\mathrm{u}=$ fluid velocity, $\mathrm{p}=$ fluid pressure, $\rho=$ density, and $\mu=$ fluid dynamic viscosity. The different terms correlated with the inertial forces (1), pressure forces (2), viscous forces (3), and the external forces used on the fluid (4). (Comsol, 2017).

For solving the RANS (Reynolds-averaged Navier-Stokes) equations, the finite-volume method is applied by Flow-3D. The formation of the rectangular grid of cells (meshes) is based on dividing up the computational domain. The rectangular mesh system can be simply applied since the regular nature of rectangular grids are accessible. The solution is applied to a unit cell after mesh generation is completed on the divided computational domain. The computational cells are known in a three-dimensional system (x-direction (i), y-direction (j) and z-direction (k)). In the middle of cells, numerical quantities are considered; however, the calculation of vector and tensors are performed at the cell faces. Figure 3-11 demonstrates the grid system for Flow-3D (Usta, 2014). 


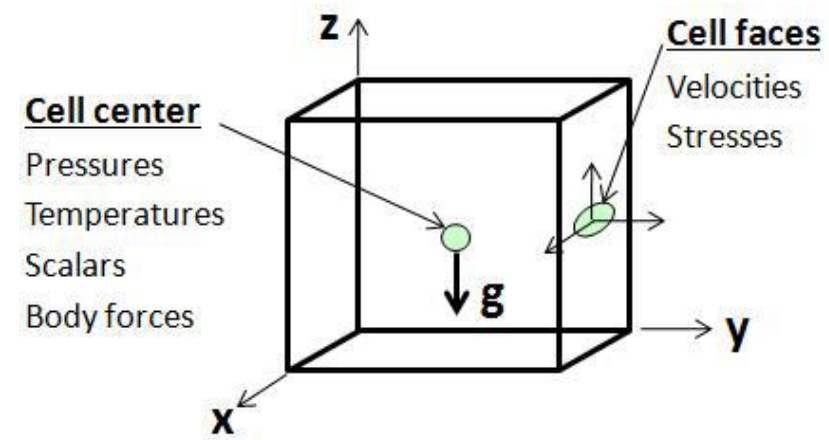

Figure 3-11: Grid System for Flow 3D (Flow 3D Advanced Hydraulic Training-2012).

\subsubsection{Geometry}

Two scenarios of the perforated pipe are investigated in Flow-3D. The three-dimensional solid geometry of the perforated pipe is drawn by AutoCAD-3D and imported to Flow-3D software. The location of the perforations and the distance between perforations are specified in AutoCAD3D. In addition, the minimum water level inside the perforated should be calculated with the regards of the number of perforations.

\subsubsection{Meshing}

As mentioned before, a mesh is part of the flow domain into fairly small areas called cells. In these cells, numerical values like velocity and pressure are calculated. For any CFD modeling, finding the proper mesh domain and mesh cell size is crucial. The accuracy of the results and the simulation time are based on the mesh and cell size. Minimizing the number of meshes is important as long as they provide sufficient resolution to capture the significant features of the geometry and flow detail. The best way to find the critical mesh size is to start with large mesh and then gradually decrease the mesh size until the results no longer change meaningfully (Chanel, 2008). It should be kept in mind that selecting a very small mesh size can significantly increase the run time and creates a need for huge computer storage. In this research, the connected mesh blocks (nested meshes) method is used. A large block of mesh is applied for the entire perforated pipe (submerged the pipe into the mesh blocks) and small meshes are used for the perforations area with the size of half of the perforations. Figure 3-12 demonstrates mesh generation for one of the case studies in FLOW-3D. 


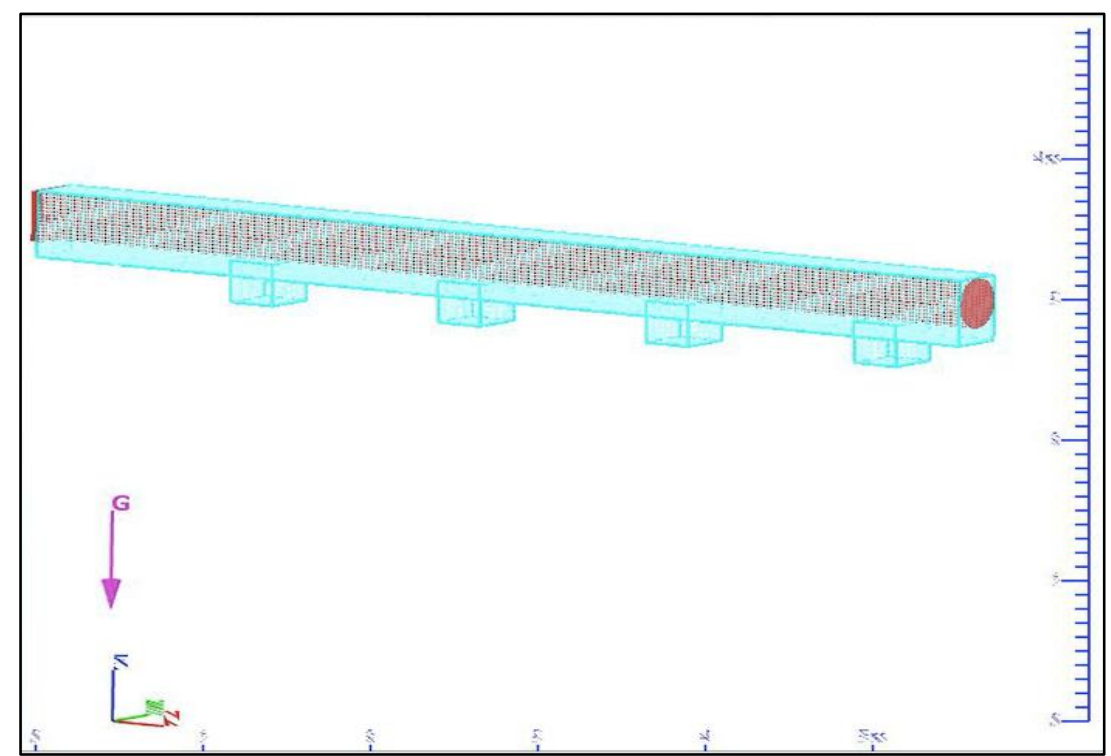

Figure 3-12: Mesh generation for the perforated pipe.

\subsubsection{Boundary Conditions}

One of the most significant phases of the numerical flow analysis is finding proper boundary conditions. According to the physical conditions, the boundary conditions must follow to the geometry of the simulated object (Usta, 2014). Since we are not using 2-phase simulation (air \& flow), the boundary condition in this research is the inner wall of the perforated pipe. The height of the water inside the pipe is in z-direction, the thickness of the perforated pipe (cross-section view) is in $\mathrm{y}$-direction and the length of the pipe is in $\mathrm{x}$-direction. 


\section{Chapter 4 Case Study}

\subsection{Introduction}

In this chapter, the case study of this research (Underground Bioretention System of Sustainable Sidewalk at Queensway Avenue) is reviewed precisely. Some of the parameters, such as input data for different modeling approaches are from this case study while the other inputs are taken from literature. This bioretention facility initially has two underground bioretention cells and a dual OPSD 400.07 catch basin as the inlet of the system. For the nature of this research, different inlet design configurations with various design storms are investigated based on this case study.

\subsection{Underground Bioretention System of Sustainable Sidewalk}

The underground bioretention project was commenced by Toronto Water (the city's water authority) in 2008 in order to assess the performance of the underground bioretention system for increasing water quality by pollutants removal and controlling surface runoff. This project has used the Silva cells provided by Deep Root Canada Corp.. The city of Toronto in conjunction with Ryerson University and Deep Root Canada Corp. has installed a proof-of-concept bioretention system. The location of the project is on the north side of Queensway Avenue between Moynes and Berl Avenue in the city of Toronto (www.deeproot.com). Figure 4-1 shows the location of the bioretention system at Queensway Avenue.

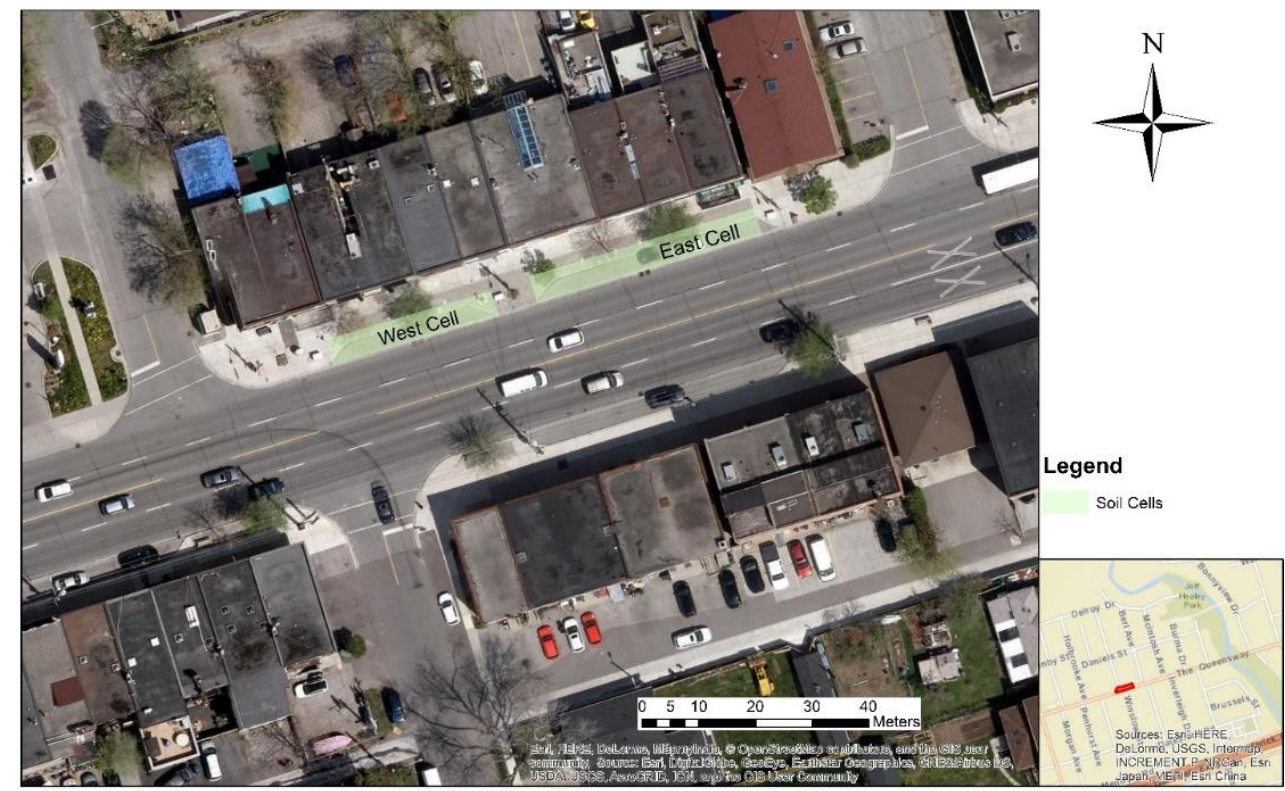

Figure 4-1: Site Location of the Bioretention System at Queensway Avenue in Toronto. 
Two trenches were excavated for two underground bioretention cells by the contractor (Pave-Al); there are two tree openings that overlapped the sidewalk area and the parking bays. The size of the trenches that fit each bioretention cell is $18.08 \mathrm{~m} \times 3.2 \mathrm{~m}$ with a depth of $1.20 \mathrm{~m}$. An impermeable geotextile fabric on sides and a concrete slab at the bottom covered the bioretention cell; that means there was no infiltration to the native soil surrounding the bioretention cells (www.deeproot.com). Figure 4-2,4-3 and 4-4 demonstrates the pilot project design and construction procedures.

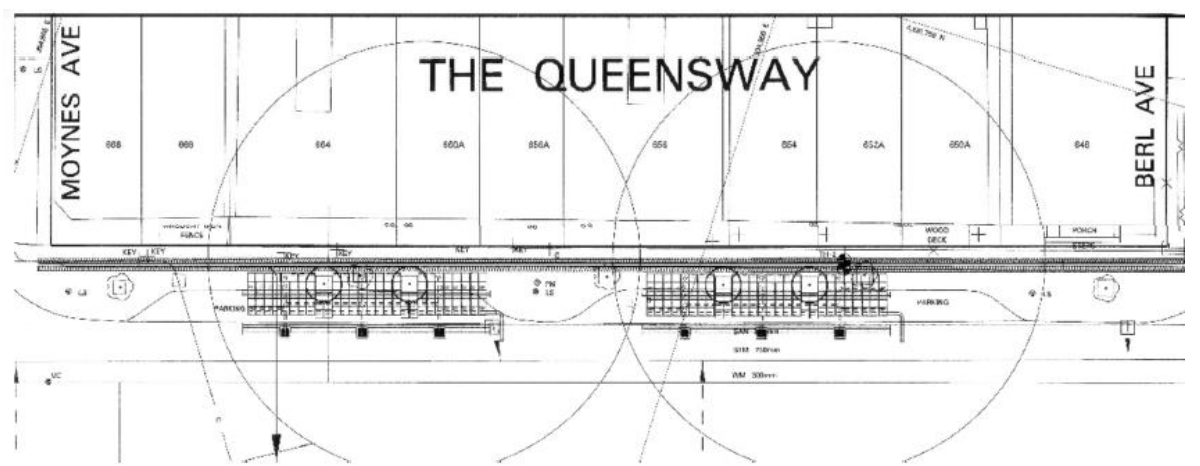

Figure 4-2: Pilot Project Design (Toronto Water,2017).

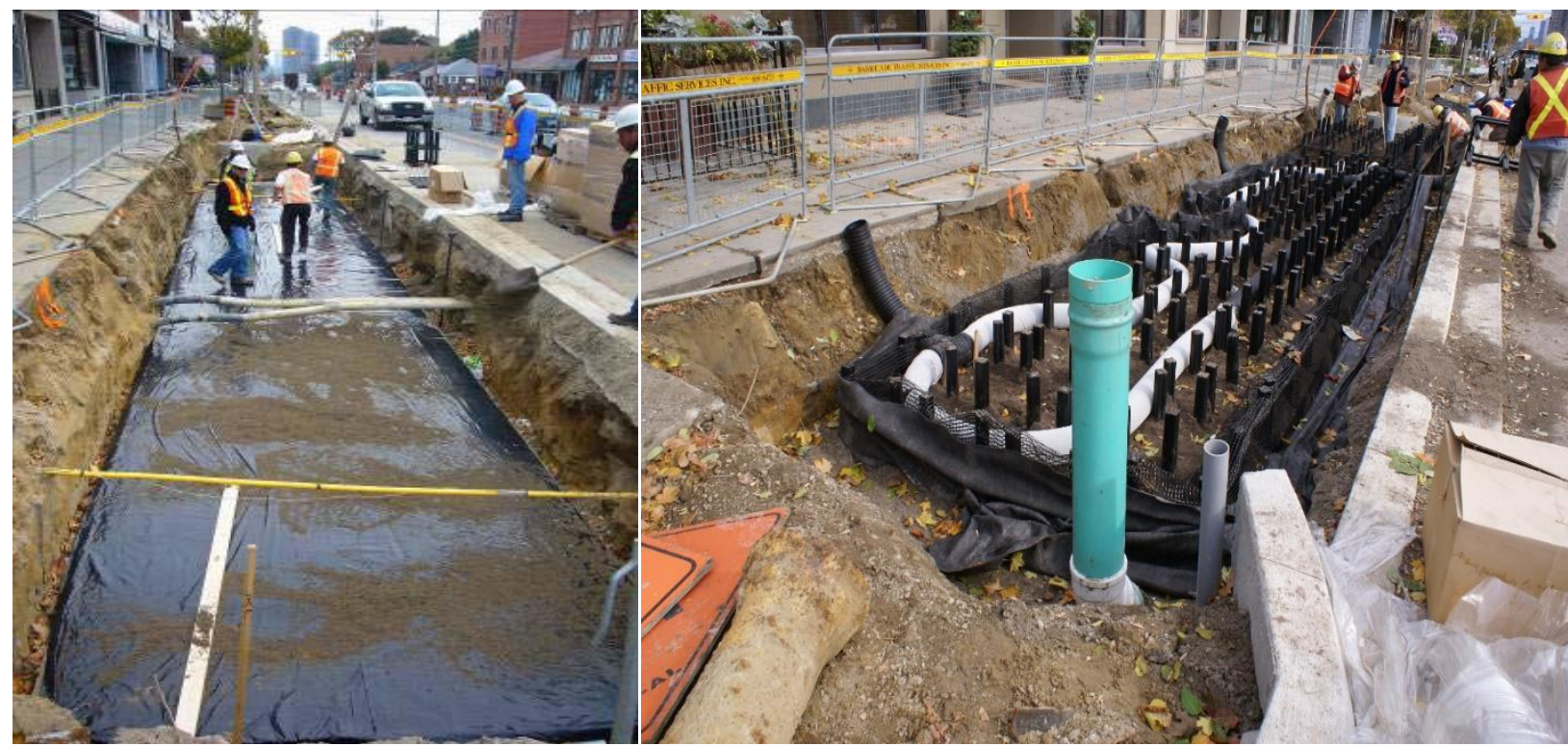

Figure 4-3, 4-4: Installation of the bioretention facility \& Upper perforated pipe for flow distribution on the top of bioretention cell and catch basin connection on the top right.

The dual catch basin is connected with a $20 \mathrm{~cm}$ (8 inch) PVC pipe to the top of the bioretention cell and conveys the surface runoff from the roadway and nearby sidewalk into the underground bioretention system. The distribution pipe is a horizontally laid $15 \mathrm{~cm}$ (6 inches) perforated PVC pipe loop that diverts surface runoff on the top of the bioretention cell that is assumed to be distributed uniformly. An underdrain pipe is a $20 \mathrm{~cm}$ (8 inches) perforated PVC flow control pipe 
that installed at the bottom of the trench and convey excess runoff from bottom of bioretention cell to storm sewer system (www.deeproot.com) (Refer to Figure 4-5).

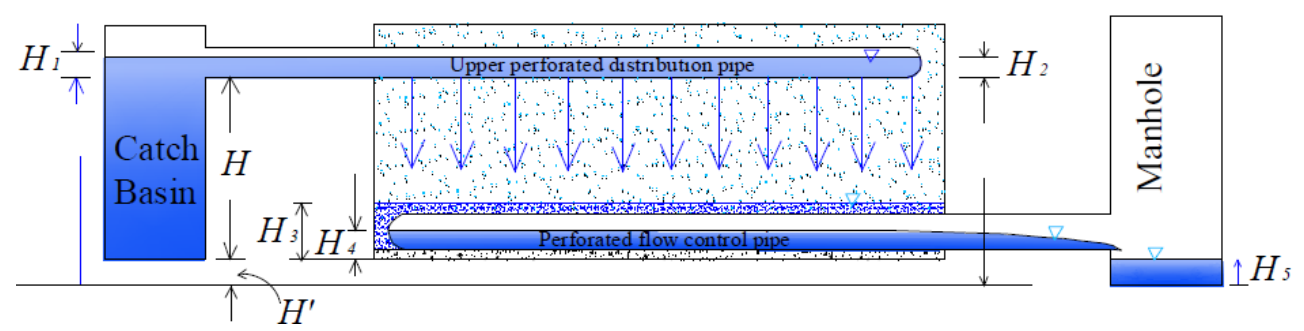

Figure 4-5: Definition Sketch of Bioretention System Cross Section (Udin, 2012).

This bioretention facility has the capability to treat, retain and detain most of the captured stormwater runoff from its catchment area. The AASHTO H-20 loading requirements are also considered in the design of this bioretention facility in order to support parking. Each bioretention cell provides $16 \mathrm{~m}^{3}\left(600 \mathrm{ft}^{3}\right)$ per tree. The bioretention soil mix design is sand, mulch, natural soils, and clay clumps and the void space is between 10-20\% when un-compacted (Toronto Water,2017). As mentioned before, loamy sand soil was selected for this research due to the literature and the characteristics of this soil. Table 4-1 shows different soil characteristics in SI units.

Table 4-1: Soil characteristics (Rossman, 2008).

\begin{tabular}{|c|c|c|c|c|c|c|}
\hline $\begin{array}{c}\text { Soil Texture } \\
\text { Class }\end{array}$ & $\begin{array}{c}\text { Hydraulic } \\
\text { Conductivity } \\
\text { (mm/hr) }\end{array}$ & $\begin{array}{c}\text { Suction } \\
\text { Head } \\
\text { (mm) }\end{array}$ & $\begin{array}{c}\text { Porosity } \\
\text { (fraction) }\end{array}$ & $\begin{array}{c}\text { Field } \\
\text { Capacity } \\
\text { (fraction) }\end{array}$ & $\begin{array}{c}\text { Wilting } \\
\text { Point } \\
\text { (fraction) }\end{array}$ & $\begin{array}{c}\text { Initial } \\
\text { Deficit } \\
\text { (fraction) }\end{array}$ \\
\hline Sand & 120.34 & 49.02 & 0.437 & 0.062 & 0.024 & 0.413 \\
\hline Loamy Sand & 29.97 & 60.96 & 0.437 & 0.105 & 0.047 & 0.390 \\
\hline Sandy Loam & 10.92 & 109.98 & 0.453 & 0.190 & 0.085 & 0.368 \\
\hline Loam & 3.30 & 88.90 & 0.463 & 0.232 & 0.116 & 0.347 \\
\hline Silt Loam & 6.60 & 169.93 & 0.501 & 0.284 & 0.135 & 0.366 \\
\hline Sandy Clay & 1.52 & 219.96 & 0.398 & 0.244 & 0.136 & 0.262 \\
\hline Loam & 1.02 & 210.06 & 0.464 & 0.310 & 0.187 & 0.277 \\
\hline Clay Loam & 1.02 & 270.00 & 0.471 & 0.342 & 0.210 & 0.261 \\
\hline Silty Clay & 0.51 & 240.03 & 0.430 & 0.321 & 0.221 & 0.209 \\
\hline Loam & 0.51 & 290.07 & 0.479 & 0.371 & 0.251 & 0.228 \\
\hline Sandy Clay & 0.25 & 320.04 & 0.475 & 0.378 & 0.265 & 0.210 \\
\hline Silty Clay & & & & & & \\
\hline Clay & 0.964 & & & & & \\
\hline
\end{tabular}


In the future, when the two trees become mature, they will increase the effectiveness of the stormwater management by evapotranspiration of the infiltrated runoff by their root systems and shading; and they will also capture and evaporate some of the rainfall using their canopies. The west cell was closed later by covering the catch basin grate with a solid cover to create a control and test scenario (Toronto Water,2017). After a couple of years, the monitoring equipment has installed by Toronto Water, in collaboration with Ryerson University to evaluate the quantity and quality of stormwater runoff from inflow and outflow of the bioretention cell. It has been suggested that monitoring the capability and performance of the system over a span of 10 to 20 years should be continued to observe whether the bioretention system supports large, mature trees and creates a more efficient, ecological stormwater system. Figure 4-6, 4-7 illustrate the tree cell and bioretention project after the construction.

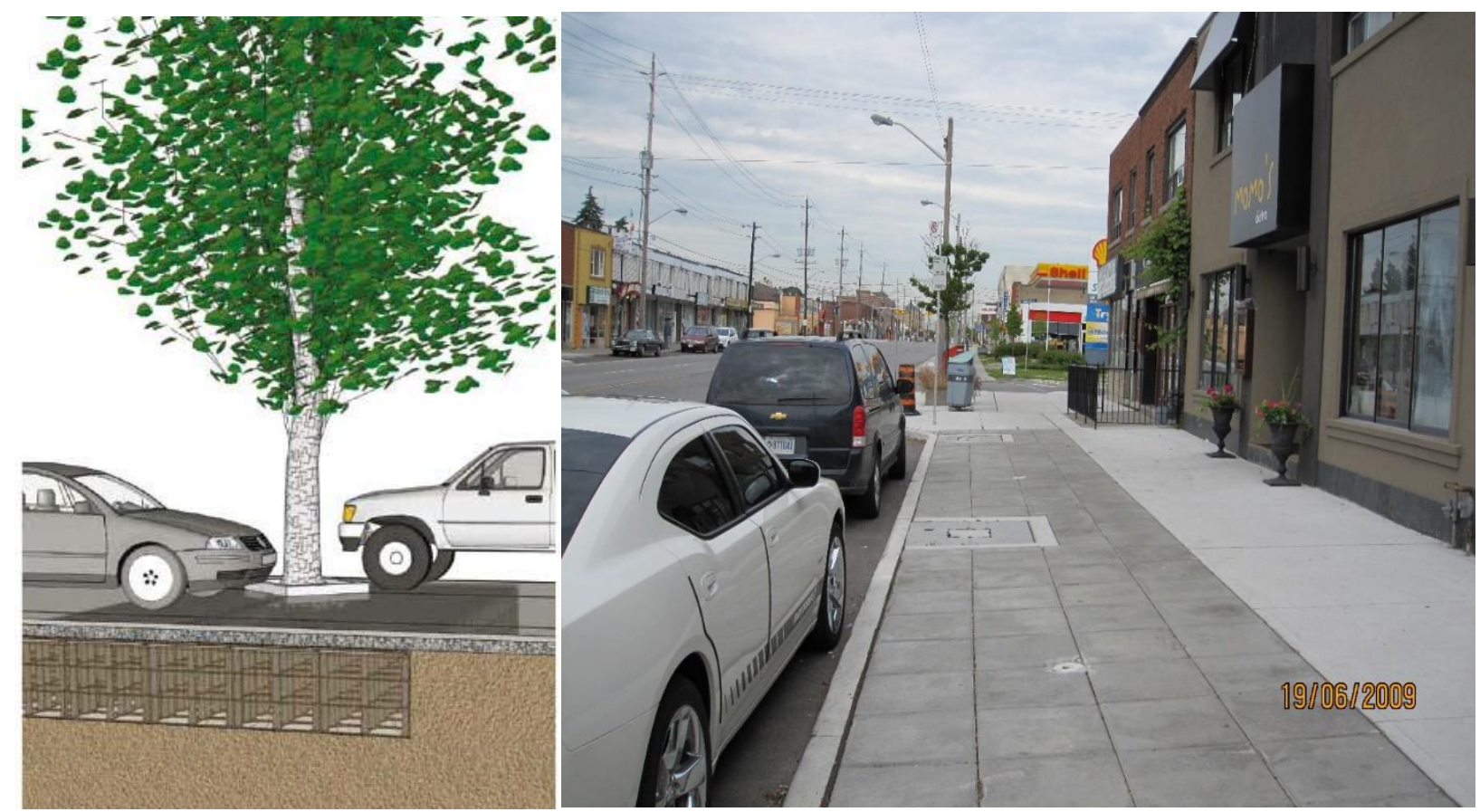

Figure 4-6, 4-7: Tree cell of underground Bioretention (www.deeproot.com), Finished parking lay-by and sidewalk on top of the bioretention facility.

The monitoring program was performed between 2015 \& 2017 with two main purposes:

1) Measure rainfall at the site, runoff flow rates at the inlet and outlet related to the rainfall, cell moisture and water level inside the bioretention cell 
2) Collect water samples during rainfall events at the inlet and outlet, prepare and send samples to the City of Toronto's Toronto Water Laboratory to analyze the concentration of the following parameters:

- Aluminum

- Biochemical Oxygen Demand (BOD)

- Chloride

- Copper

- Iron

- Lead

- Nickel

- Nitrate (as N)

- Total Phosphorus(mg/L)

- Total Suspended Solids (TSS)

- Zinc

For the small events the autosampler only collected the inlet samples and incomplete set of samples were not sent for analyzing at the City of Toronto's Toronto Water Laboratory. Figure 4-8, 4-9 demonstrates the autosampler at the Queensway Avenue, and inlet \& outlet samples were collected by the autosampler during a rainfall event.
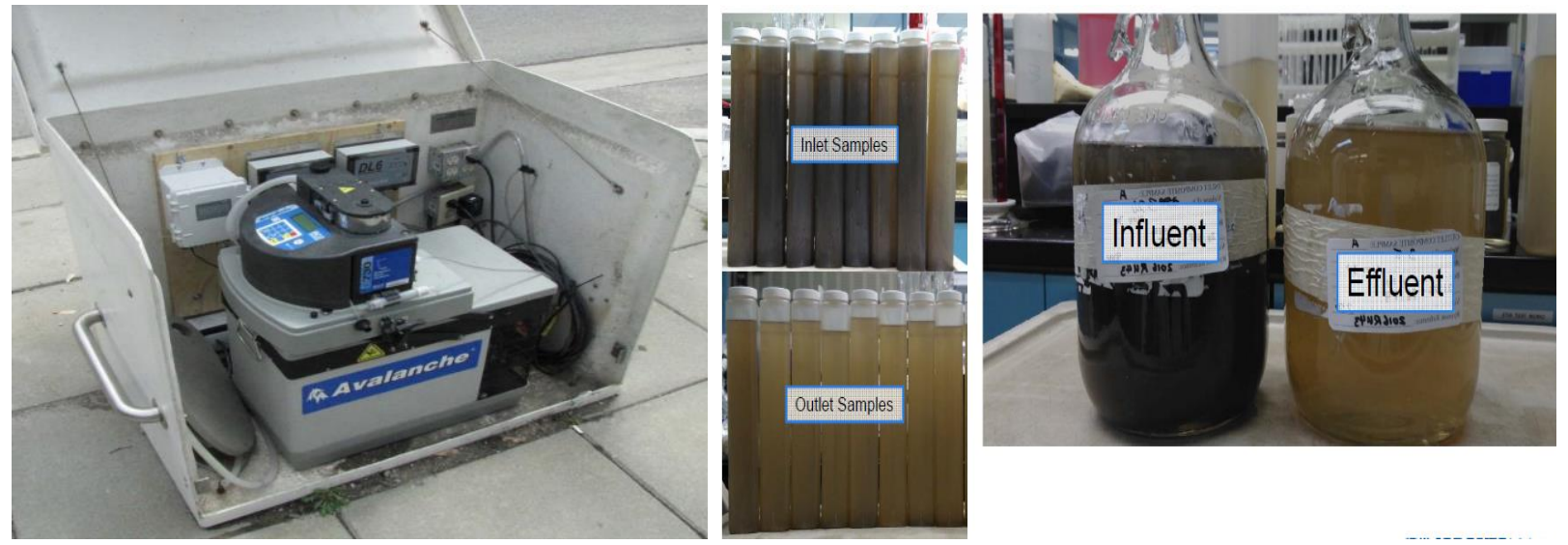

Figure 4-8, 4-9: The autosampler device at the Queensway Avenue, and inlet \& outlet samples that collected by the autosampler on a rainfall event (Toronto Water,2017).

Table 4-2 below also shows a sample of pollutants removal percentage that was collected on November 2, 2016 (Toronto Water,2017): 
Table 4-2: A sample of pollutant removal in 2016.

\begin{tabular}{|c|c|c|c|}
\hline \multicolumn{5}{|c|}{ November 2, 2016 Sample } \\
\hline Pollutant & Influent (mg/L) & Effluent $(\mathrm{mg} / \mathrm{L})$ & Percent Reduction \\
\hline Aluminum & 0.853 & 0.138 & $83.8 \%$ \\
\hline $\begin{array}{c}\text { Biochemical Oxygen } \\
\text { Demand (BOD) }\end{array}$ & 63.00 & 18 & $71.4 \%$ \\
\hline Chloride & 25.9 & 21.5 & $17.0 \%$ \\
\hline Copper & 0.0302 & 0.0144 & $52.3 \%$ \\
\hline Iron & 2.43 & 0.287 & $88.2 \%$ \\
\hline Lead & 0.00584 & 0.00064 & $89.0 \%$ \\
\hline Nickel & 0.00383 & 0.00316 & $17.5 \%$ \\
\hline Nitrate (as N) & 0.02 & 0.68 & $-1.32 \%$ \\
\hline Total Phosphorus & 0.607 & 0.082 & $96.5 \%$ \\
\hline Total Suspended & 58 & 2 & $76.6 \%$ \\
\hline Solids (TSS) & 0.106 & & $76.4 \%$ \\
\hline Zinc & & 0.025 & \\
\hline
\end{tabular}

The total drainage area for this bioretention facility is about $1,074 \mathrm{~m} 2$ with a $0.8 \%$ slope toward the east (Figure 4-10). The north side of The Queensway, a busy road used by over 23,000 vehicles per day (Traffic Safety Unit - City of Toronto, 2017), the associated sidewalk, and a small grass area at the intersection on Moynes Avenue are main sections of the drainage area (Li et al,2018).

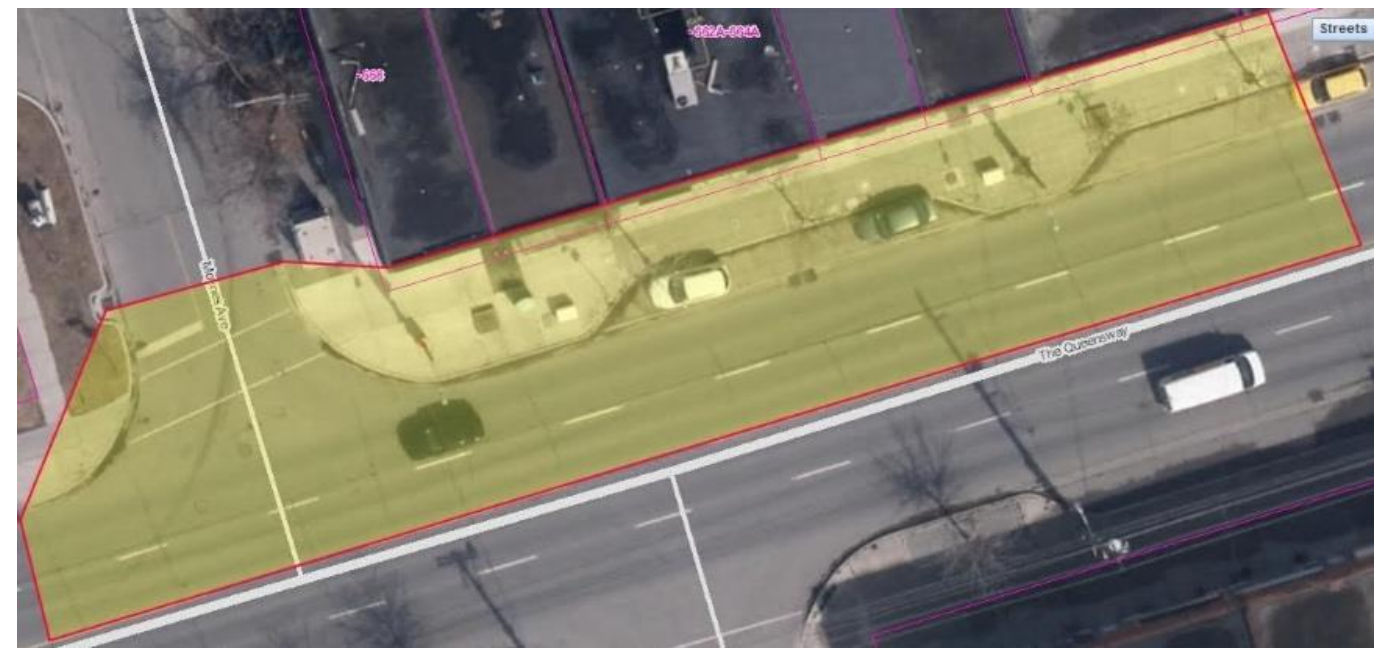

Figure 4-10: Catchment area of the bioretention Cell (Li et al,2018).

After almost six years, the effect of having a more ecological stormwater system (the bioretention facility) appeared in terms of the healthy growth of trees. Figure 4-11 verifies the healthy growth of trees before and after the bioretention in 2014 . 

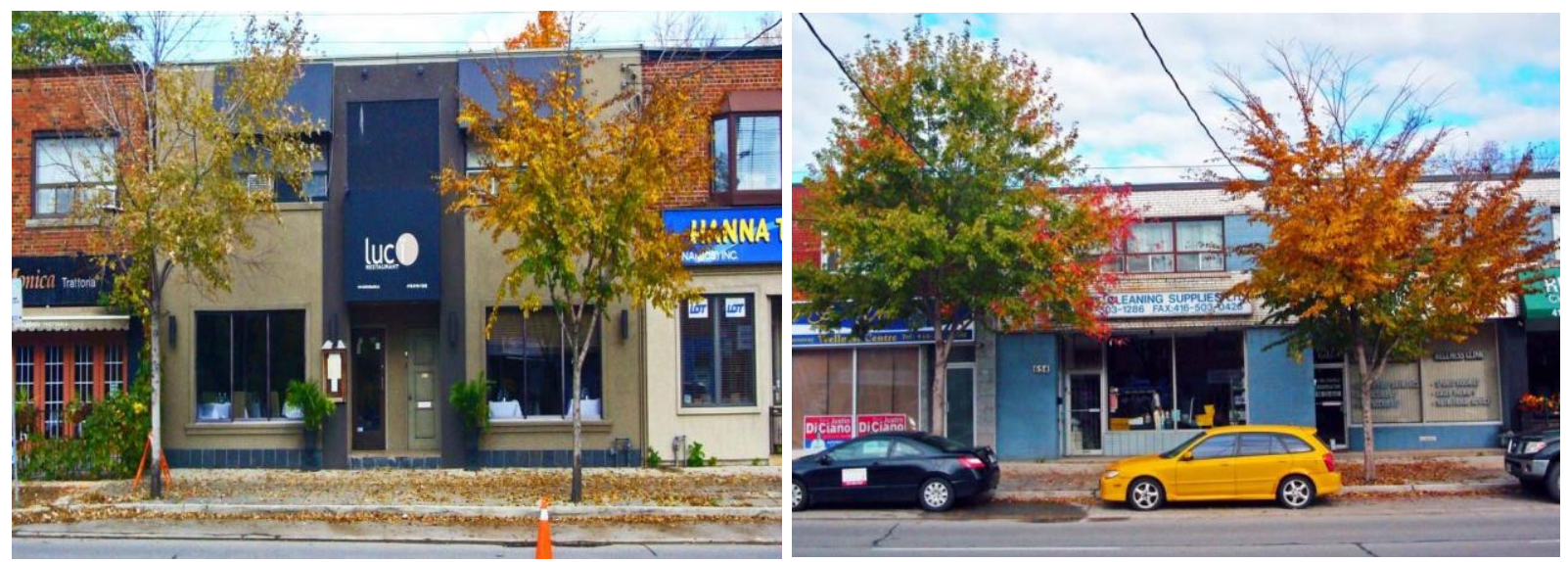

Figure 4-11: Before (left) and after the bioretention facility in 2014 (Toronto Water,2017).

\subsection{Rainfall Intensity}

As mentioned before, the Chicago design storms with different return periods $(2,5,10,25,100$ year) were used to create the runoff hydrographs for the simulation. Typically, bioretention facilities are part of the minor system that are only designed for the 2-year return period - for improving the design of the system different design storms up to 100-year were used. With equation (3-1) and table 4-3 from Wet Weather Flow Management Guidelines from the City of Toronto (2006), hyetographs of the different design storms were generated by PCSWMM software for 4 hours design storms (Refer to Figure 4-13).

Table 4-3: A \& C parameters for calculating rainfall intensity (Wet Weather Flow Management Guidelines (2006)).

\begin{tabular}{|c|c|c|}
\hline $\begin{array}{c}\text { Return } \\
\text { Period } \\
\text { (Year) }\end{array}$ & $\mathbf{A}$ & $\mathbf{C}$ \\
\hline 2 & 21.8 & -0.78 \\
\hline 5 & 32 & -0.79 \\
\hline 10 & 38.7 & -0.80 \\
\hline 25 & 45.2 & -0.80 \\
\hline 50 & 53.5 & -0.80 \\
\hline 100 & 59.7 & -0.80 \\
\hline
\end{tabular}

Please note that A \& $\mathrm{C}$ units are in hour and B is always 0. Figure 4-12 shows rainfall intensity curves for City of Toronto. 


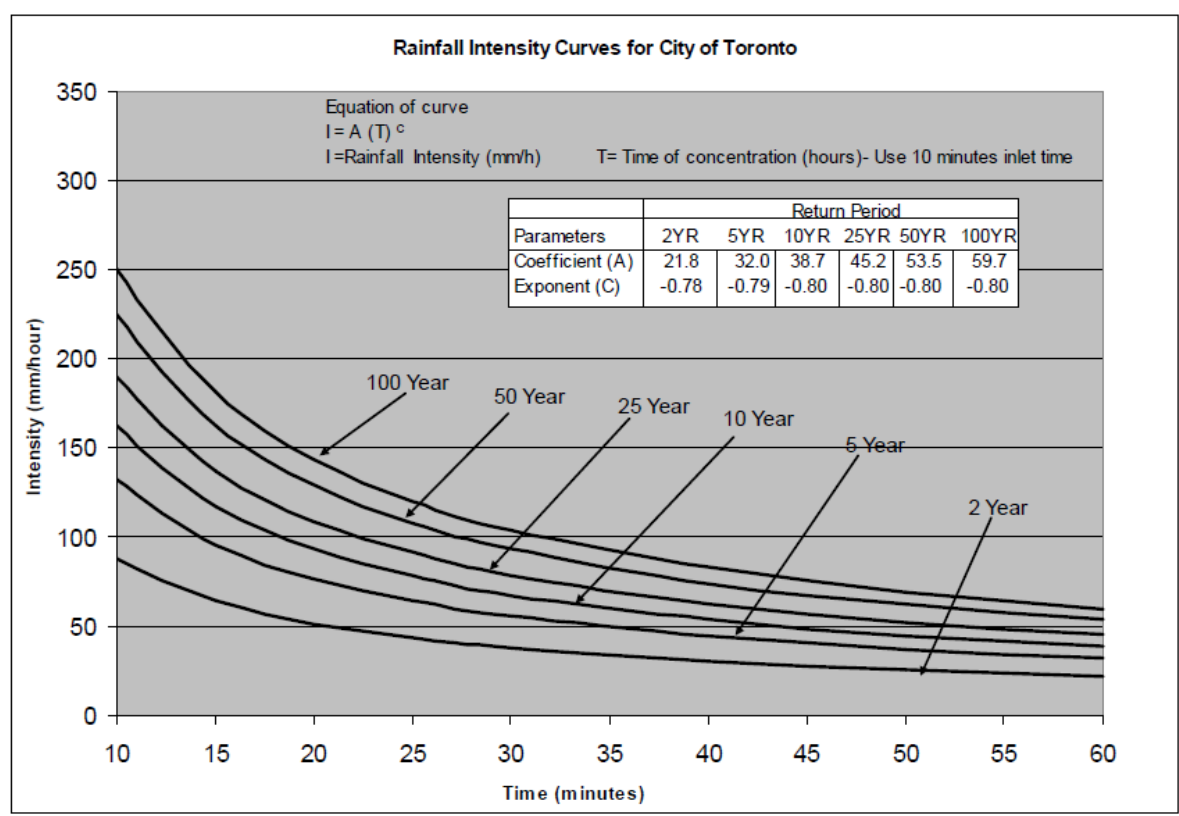

Figure 4-12: Rainfall Intensity Curves for City of Toronto (Wet Weather Flow Management Guidelines (2006)).

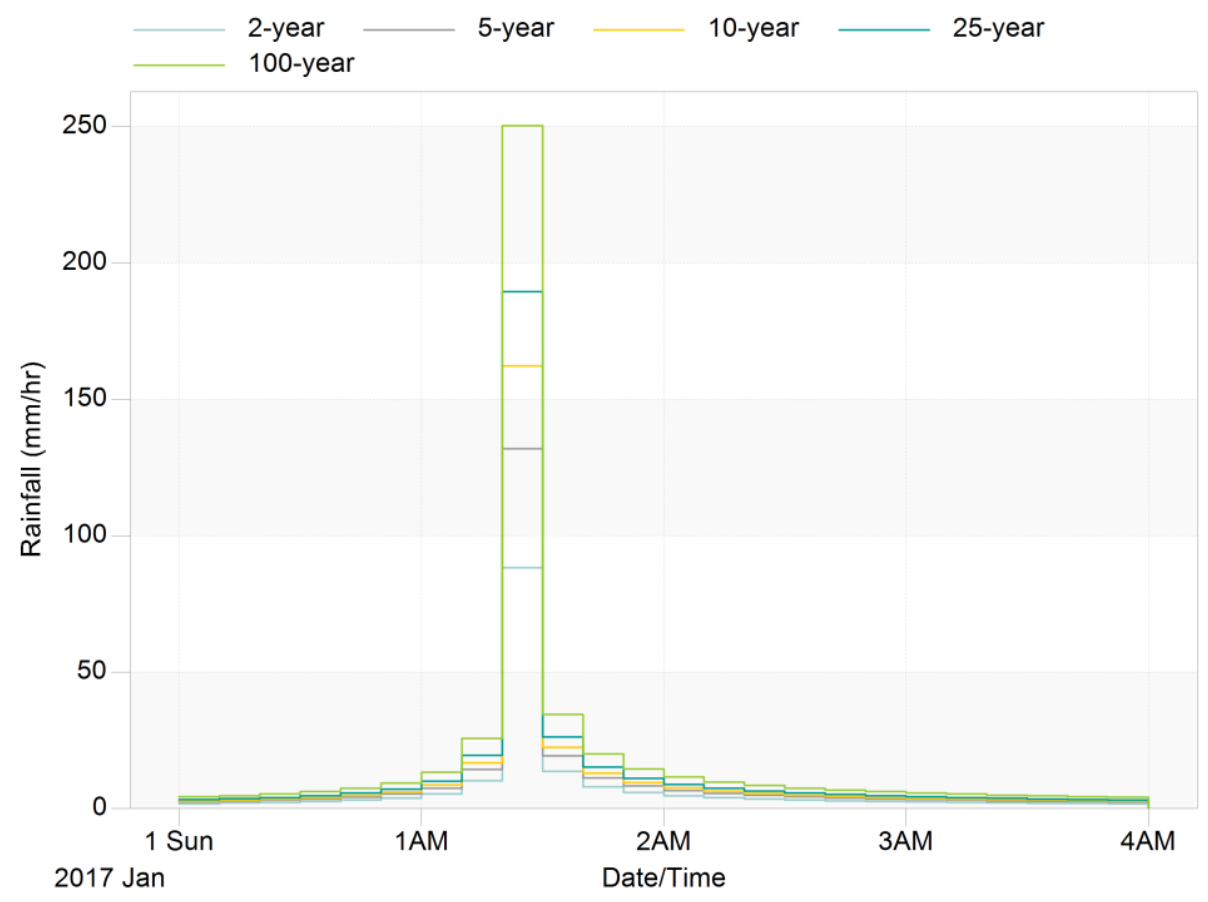

Figure 4-13: Different design storms hyetographs generated by PCSWMM. 


\section{Chapter 5 Results and Discussion}

\subsection{Introduction}

The modeling approaches discussed in Chapter 3 are used to simulate the performance of the bioretention facility according to the case study (Chapter 4) of this research. Several scenarios including some hypothetical scenarios with different design storms and inlet configurations were investigated. First, Inlet hydrographs (captured runoff), bypass (from catch basin) hydrographs, and outlet hydrographs from the bioretention facility along with peak runoff reduction \& volume reduction percentage will be discussed. Second, the results of FLOW-3D (finite element model) modeling including water profiles for different flow rates vs percentage of utilization of the bioretention cell and finding the reduction scale factor will be shown. Finally, the new design and size of the bioretention cell will be determined with the reduction scale factor and the performance of the bioretention will be reviewed compared to the previous sizing. Initially, we need to define some input parameters for the first approach which is SWMM modeling.

\subsection{Input parameters for SWMM approach}

Some of the input parameters for subcatchments, conduits (major \& minor), and bioretention layers must be defined prior to the simulation. Table 5-1 shows input parameters for subcatchments:

Table 5-1: Input parameters for subcatchments.

\begin{tabular}{|c|c|c|}
\hline & DRAINAGE-AREA & BIORETENTION \\
\hline Area (ha) & 0.1074 & 0.0057856 \\
\hline Flow Length (m) & 74.554 & 18.081 \\
\hline Width (m) & 14.352 & 3.2 \\
\hline Slope (\%) & 0.8 & 0.5 \\
\hline Imperv. (\%) & 100 & 0 \\
\hline N Imperv & 0.011 & 0.011 \\
\hline N Perv & 0.1 & 0.24 \\
\hline Dstore Imperv(mm) & 1.25 & 0.127 \\
\hline Dstore Perv(mm) & 2.5 & 0.508 \\
\hline Zero Imperv (\%) & 100 & 0 \\
\hline
\end{tabular}

Area and slope of the main subcatchment (DRAINAGE-AREA) are based on the surveying in June 2016 by RU team. Flow length or longest flow path is obtained from Google maps for DRAINAGE-AREA subcatchment. Area, flow length, and width of the bioretention subcatchment are obtained from excavated trench size which is $18.08 \mathrm{~m} \times 3.2 \mathrm{~m}$. The slope of bioretention 
subcatchment is $0.5 \%$ based on recent literature. Manning's $\mathrm{n}$ of overland flow and depression storage of impervious and pervious areas were selected based on SWMM manual for both subcatchments. In addition, Table 5-2 demonstrates input parameters for conduits:

Table 5-2: Input parameters for conduits.

\begin{tabular}{|c|c|c|}
\hline & STREET & SEWER1 \\
\hline Length $(\mathrm{m})$ & 74.552 & 70 \\
\hline Roughness & 0.016 & 0.011 \\
\hline Inlet Elevation (m) & 91.03 & 90.43 \\
\hline Outlet Elevation (m) & 90.43 & 89.87 \\
\hline Cross-Section & Irregular & Circular \\
\hline Geom 1 (m) & Transect: Street1 & 0.5 \\
\hline
\end{tabular}

The length of the section of street equals to the longest flow path before stormwater runoff captures by the inlet. Figure 5-1 shown below the transect: Street1:

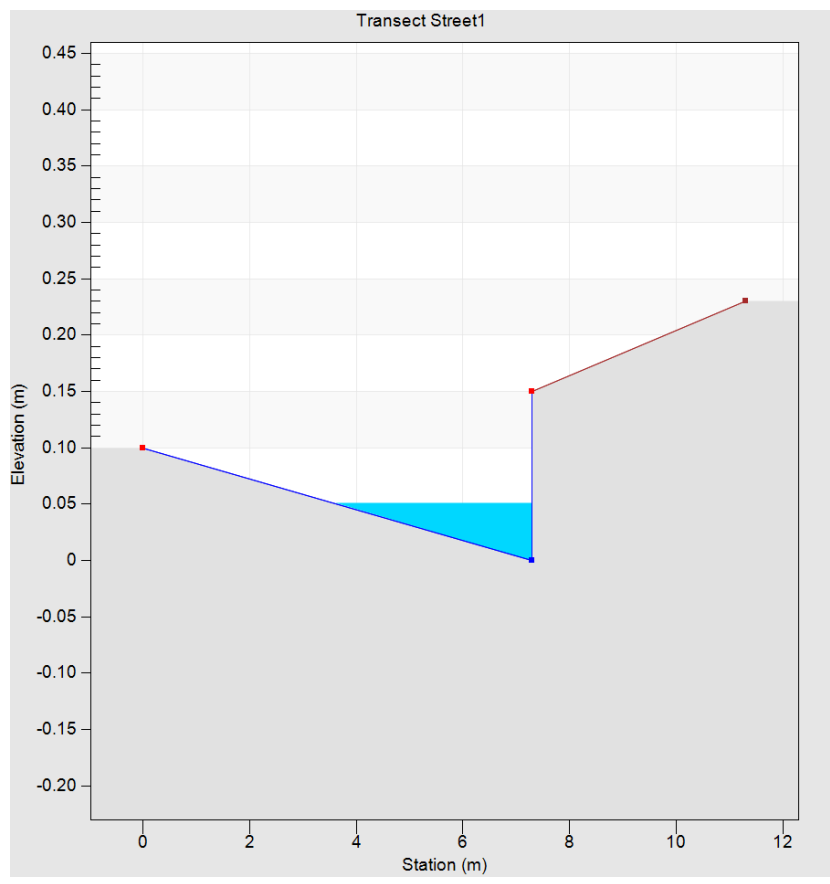

Figure 5-1: transect: Street1 in PCSWMM.

The description of this transect is: Half street, width $=7.3 \mathrm{~m}$, curb $=0.15 \mathrm{~m}$, cross-slope $=$ $0.0205 \mathrm{~m} / \mathrm{m}$, bank-slope $=0.02 \mathrm{~m} / \mathrm{m}$, bank-height $=0.23 \mathrm{~m}$. Also, Table $5-3$ shows input parameters for LID control: 
Table 5-3: Input parameters for LID control (Bioretention cell).

\begin{tabular}{|c|c|c|c|c|c|c|}
\hline \multicolumn{7}{|c|}{ Surface Layer } \\
\hline $\begin{array}{l}\text { Berm Height } \\
(\mathrm{mm})\end{array}$ & \multicolumn{2}{|c|}{$\begin{array}{l}\text { Vegetation Volume } \\
\text { (fraction) }\end{array}$} & \multicolumn{2}{|c|}{$\begin{array}{l}\text { Surface Roughness } \\
\text { (Manning's n) }\end{array}$} & \multicolumn{2}{|c|}{ Surface Slope (\%) } \\
\hline 0.001 & \multicolumn{2}{|c|}{0} & & 0.1 & \multicolumn{2}{|c|}{0.001} \\
\hline \multicolumn{7}{|c|}{ Soil Layer } \\
\hline Thickness (mm) & $\begin{array}{l}\text { Porosity } \\
\text { (volume } \\
\text { fraction) }\end{array}$ & $\begin{array}{c}\text { Field } \\
\text { Capacity } \\
\text { (volume } \\
\text { fraction) }\end{array}$ & $\begin{array}{l}\text { Witling } \\
\text { Point } \\
\text { (volume } \\
\text { fraction) }\end{array}$ & $\begin{array}{l}\text { Conductivity } \\
(\mathrm{mm} / \mathrm{hr})\end{array}$ & $\begin{array}{l}\text { Conductivity } \\
\text { Slope }\end{array}$ & $\begin{array}{c}\text { Suction } \\
\text { Head } \\
(\mathrm{mm})\end{array}$ \\
\hline 600 & 0.437 & 0.105 & 0.047 & 29.97 & 10 & 60.96 \\
\hline \multicolumn{7}{|c|}{ Storage Layer } \\
\hline Thickness (mm) & \multicolumn{2}{|c|}{$\begin{array}{c}\text { Void Ratio } \\
\text { (voids/solids) }\end{array}$} & \multicolumn{2}{|c|}{ Seepage Rate $(\mathrm{mm} / \mathrm{hr})$} & \multicolumn{2}{|c|}{ Clogging Factor } \\
\hline 600 & \multicolumn{2}{|c|}{0.5} & & 0 & \multicolumn{2}{|l|}{0} \\
\hline \multicolumn{7}{|c|}{ Underdrain } \\
\hline $\begin{array}{l}\text { Drain Coefficient } \\
(\mathrm{mm} / \mathrm{hr})\end{array}$ & \multicolumn{2}{|c|}{ Drain Exponent } & \multicolumn{4}{|c|}{ Drain Offset Height (mm) } \\
\hline 339.17 & \multicolumn{2}{|c|}{0.5} & \multicolumn{4}{|c|}{0} \\
\hline
\end{tabular}

The surface layer's input parameters should be equal to 0 since we are using underground bioretention for most of the scenarios but instead, we used 0.001 for the nature of simulation software. The thickness of the soil layer is $600 \mathrm{~mm}$ according to the case study and the rest of the input parameters are form Table 4-1 (soil characteristics) for the loamy sand soil. In addition, conductivity slope is ranging from 5 for sands to 15 for silty clay and 10 is selected for loamy sand (Rossman, 2008). The bioretention cell in this case study doesn't have a storage layer but $600 \mathrm{~mm}$ hypothetical storage layer is selected for the software limitation. Seepage rate is equal to 0 because of impermeable geotextile fabric on sides and a concrete slab at the bottom of the bioretention cell. Finally, drain coefficient was calculated with equation (3-19) for underdrain section for 8 inches (20.32mm) underdrain pipe:

$C_{L I D}=160997 \sqrt{g} C_{d} \frac{A_{\text {orif }}}{A_{L I D}}$

Where:

$A_{\text {orif }}=2\left(\pi r^{2}\right)=2\left(\pi 0.1016^{2}\right)=0.065 \mathrm{~m}^{2}$

Assuming an orifice coefficient of 0.6 :

$$
C_{L I D}=160997 \sqrt{9.81} 0.6 \frac{0.065}{57.856}=339.17 \mathrm{~mm} / \mathrm{hr}
$$

Drain offset height is 0 for having a better drainage at the bottom of the bioretention cell. 


\subsection{Scenarios}

Six different scenarios were defined. Each scenario is assigned with a different inlet configuration and has 5 design storms which are 2,5,10,25,100-year for 4-hour storms. The inlet configurations are:

1. Single \& Twin Horizontal Bar/Fishbone catch basins.

2. OPSD400.01 catch basin.

3. Single \& Twin Grid catch basins.

4. Single \& Twin Honeycomb catch basins.

5. Curb Opening

6. Curb Cut

Inlet, outlet, and bypass hydrographs for each scenario were investigated along with peak runoff $\&$ volume reduction percentage. In the following hydrographs: Inlet of the bioretention facility= INLET, W1, OR1. The outlet from the bioretention facility =UNDERDRAIN, bypass= BYPASS 1 .

\subsubsection{Scenario 1}

The inlets are single \& twin horizontal bar/fishbone catch basins for the 4-hour storms with 2,5,10,25,100- year return periods. Figure 5-2 shows outlet, inlet \& bypass hydrographs for single $\&$ twin horizontal bar/fishbone catch basins for 4 hours design storms. In addition, Table 5-4 displays results of the 4 hours design storms for scenario 1 . 

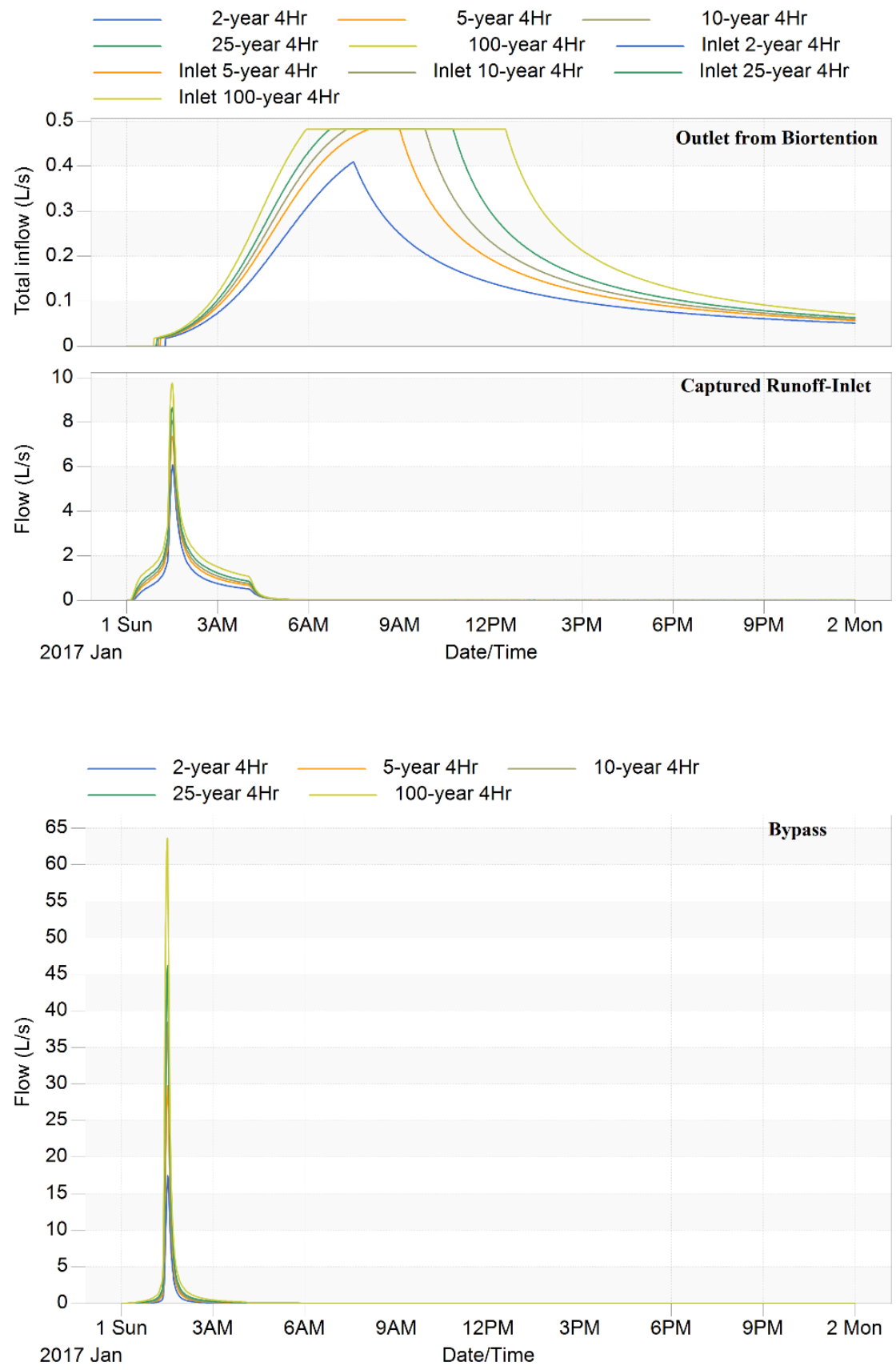

Figure 5-2: Outlet, Inlet \& bypass hydrographs for single \& twin horizontal bar/fishbone catch basins for 4 hours design storms. 
Table 5-4: Results of the 4 hours design storms for scenario 1.

\begin{tabular}{|c|c|c|c|c|c|}
\hline $\begin{array}{c}\text { Single \& twin } \\
\text { horizontal } \\
\text { bar/fishbone catch } \\
\text { basins }\end{array}$ & $\begin{array}{c}2-y e a r \\
4 \mathrm{Hr}\end{array}$ & $\begin{array}{c}5 \text {-year } \\
4 \mathrm{Hr}\end{array}$ & $\begin{array}{c}10 \text {-year } \\
4 \mathrm{Hr}\end{array}$ & $\begin{array}{c}25-\text {-year } \\
4 \mathrm{Hr}\end{array}$ & $\begin{array}{c}100 \text {-year } \\
4 \mathrm{Hr}\end{array}$ \\
\hline $\begin{array}{c}\text { Peak Runoff } \\
\text { Reduction (\%) }\end{array}$ & 24.3 & 20.2 & 17.8 & 16.6 & 12.6 \\
\hline $\begin{array}{c}\text { Volume Treated } \\
(\%)\end{array}$ & 35.6 & 32.8 & 32.2 & 32.1 & 32.8 \\
\hline
\end{tabular}

The results for both single and twin catch basin are the same according to inlet capacity curve (Figure 3-4) because the water depth never reaches $0.06 \mathrm{~m}(6 \mathrm{~cm})$ and the difference between single and twin catch basins starts after $6 \mathrm{~cm}$. The peak runoff captured by inlet happens after almost 90 minutes for 4-hour design storms. The outflow peak from the bioretention cell for 4-hour design storms happens after 8 hours for the 2-year storm and constantly occurs earlier for following design storms until approaches 6 hours for the 100-year storm. In addition, the peak outflow from the bioretention cell for 4 hours after the 2-year storm equals $0.4817 \mathrm{~L} / \mathrm{s}$ since the rate of percolation of soil reaches the hydraulic conductivity of the loamy sand soil which is $29.97 \mathrm{~mm} / \mathrm{hr}$. The volume treated percentage is the amount of stormwater that treated by the bioretention cell after 24 hours. The detention time increased significantly for all design storms and it takes almost 72 hours for runoff drains out of the system.

\subsubsection{Scenario 2}

The inlet is an OPSD400.01 catch basin for the 4-hour storms with 2,5,10,25,100- year return periods. Figure 5-3 demonstrates outlet, inlet \& bypass hydrographs for single $\&$ twin horizontal bar/fishbone catch basins for 4 hours design storms. Also, Table 5-5 explains results of the 4 hours design storms for scenario 2 . 

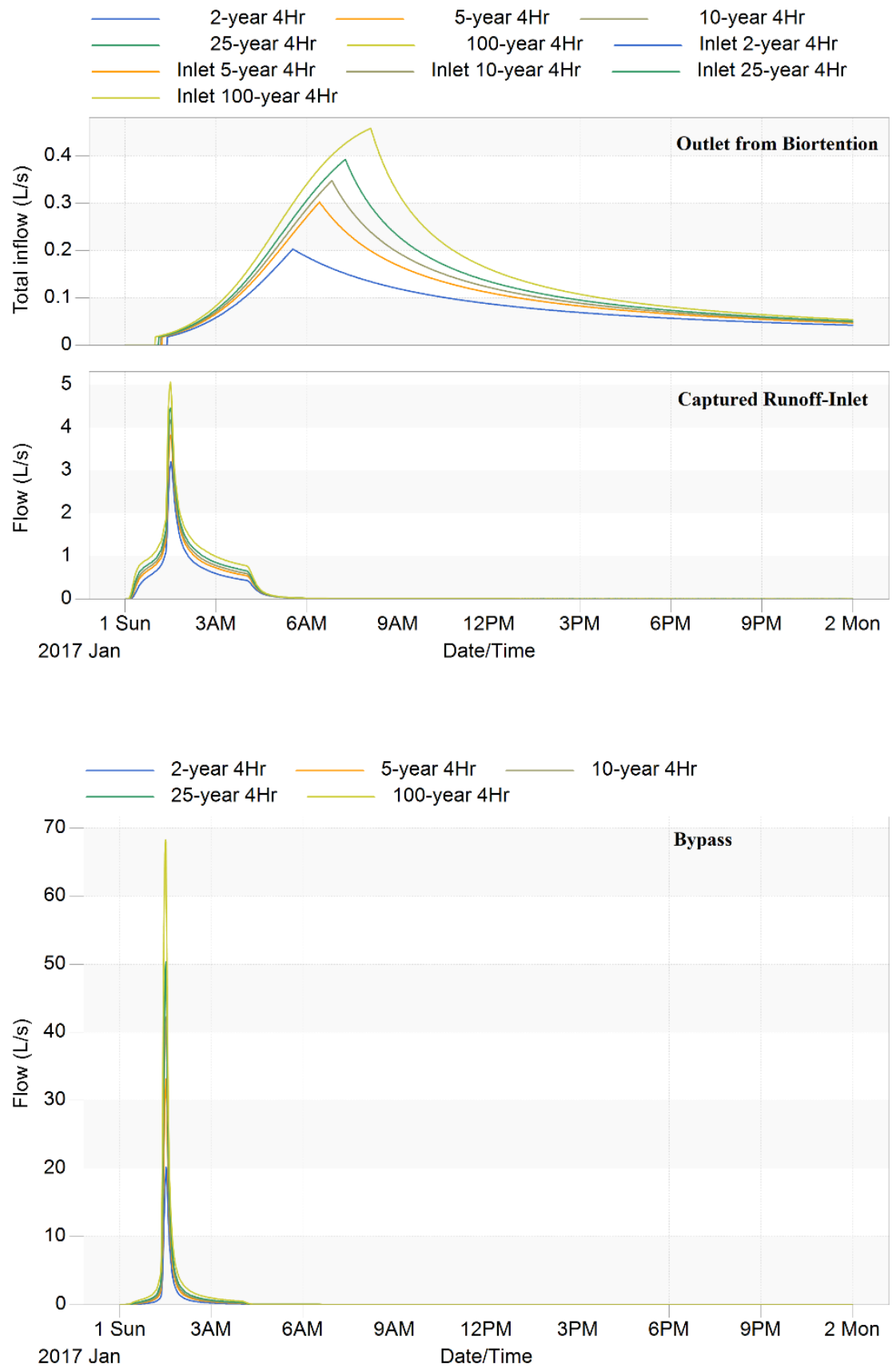

Figure 5-3: Outlet, Inlet \& bypass hydrographs for OPSD400.01 catch basin for 4 hours design storms. 
Table 5-5: Results of the 4 hours design storms for scenario 2.

\begin{tabular}{|c|c|c|c|c|c|}
\hline $\begin{array}{c}\text { OPSD400.01 } \\
\text { catch basin }\end{array}$ & $\begin{array}{c}2 \text {-year } \\
4 \mathrm{Hr}\end{array}$ & $\begin{array}{c}5 \text {-year } \\
4 \mathrm{Hr}\end{array}$ & $\begin{array}{c}10 \text {-year } \\
4 \mathrm{Hr}\end{array}$ & $\begin{array}{c}25 \text {-year } \\
4 \mathrm{Hr}\end{array}$ & $\begin{array}{c}100 \text {-year } \\
4 \mathrm{Hr}\end{array}$ \\
\hline $\begin{array}{c}\text { Peak Runoff } \\
\text { Reduction }(\%)\end{array}$ & 13.4 & 10.1 & 9.1 & 8.2 & 7.1 \\
\hline $\begin{array}{c}\text { Volume Treated } \\
(\%)\end{array}$ & 42.8 & 38.8 & 37.2 & 35.8 & 33.7 \\
\hline
\end{tabular}

The peak of the inlet hydrographs occurs after 90 minutes for 4-hour design. For 4-hour design storms, the peak of outlet hydrographs from bioretention cell occurs after 5:30 hours for the 2-year storm and moving forward for subsequent design storms until reaches 8 hours for the 100-year storm. The peak of outlet hydrographs from bioretention cell happens after 2 hours. The rate of percolation of soil didn't reach the hydraulic conductivity of the loamy sand soil. The highest volume reduction percentage is for the 2-year storm for 4-hour design storms. The volume treated percentage is the amount of stormwater that treated by the bioretention cell after 24 hours. The detention time is increased meaningfully and after 24 hours the outflows from the bioretention cell for 4-hour design storms are ranging from 0.05 to 0.06 1/s.

\subsubsection{Scenario 3}

The inlets are single \& twin grid catch basins for the 4-hour storms with 2,5,10,25,100- year return periods. Figure 5-4 illustrates outlet, inlet \& bypass hydrographs for single \& twin horizontal bar/fishbone catch basins for 4 hours design storms. Also, Table 5-6 describes results of the 4 hours design storms for scenario 3. 

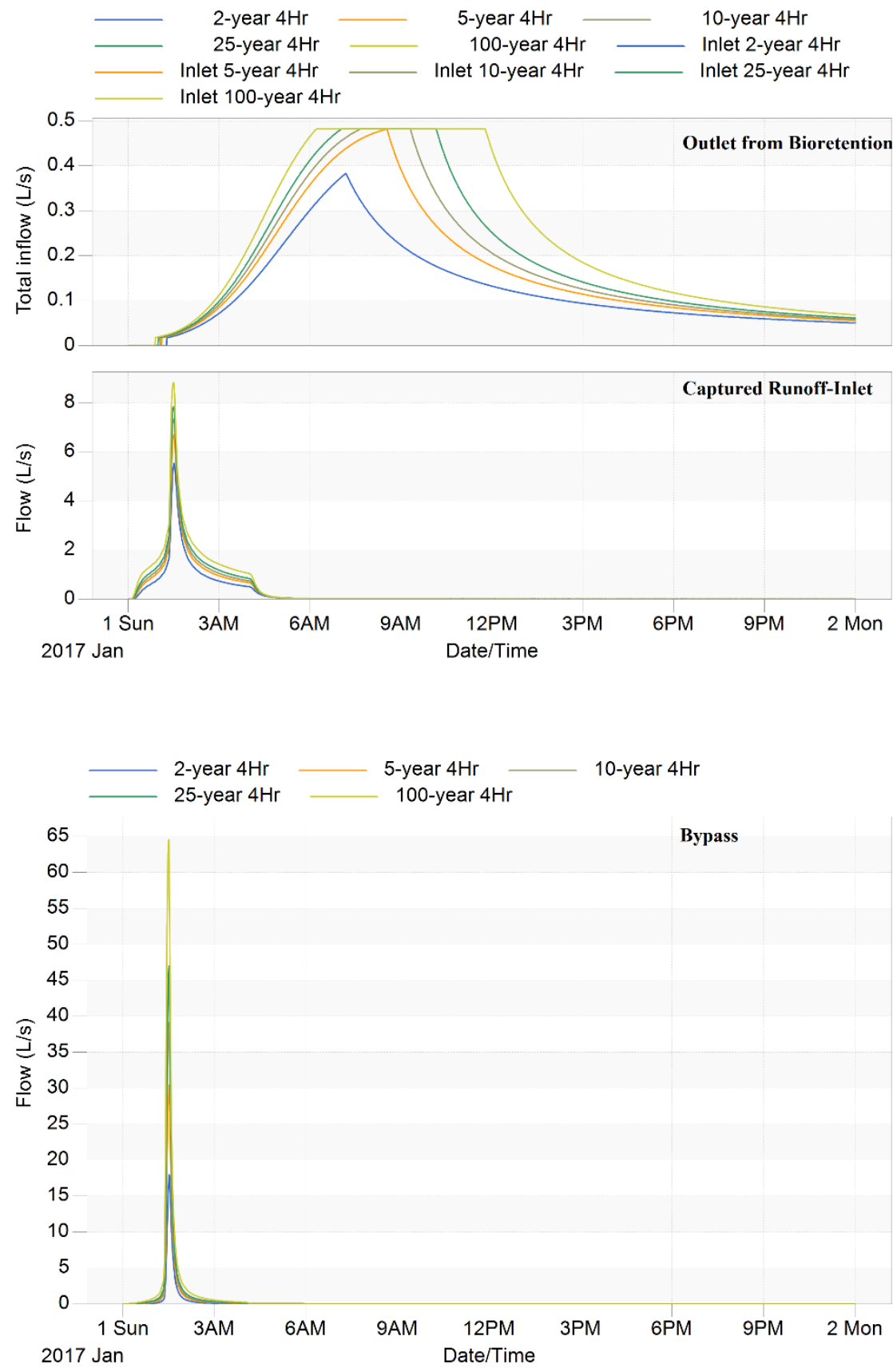

Figure 5-4: Outlet, Inlet $\&$ bypass hydrographs for single $\&$ twin grid catch basins for 4 hours design storms. 
Table 5-6: Results of the 4 hours design storms for scenario 3.

\begin{tabular}{|c|c|c|c|c|c|}
\hline $\begin{array}{c}\text { Single \& twin } \\
\text { grid catch } \\
\text { basins }\end{array}$ & $\begin{array}{c}2 \text {-year } \\
4 \mathrm{Hr}\end{array}$ & $\begin{array}{c}5 \text {-year } \\
4 \mathrm{Hr}\end{array}$ & $\begin{array}{c}10-\text { year } \\
4 \mathrm{Hr}\end{array}$ & $\begin{array}{c}25-\mathrm{year} \\
4 \mathrm{Hr}\end{array}$ & $\begin{array}{c}100 \text {-year } \\
4 \mathrm{Hr}\end{array}$ \\
\hline $\begin{array}{c}\text { Peak Runoff } \\
\text { Reduction (\%) }\end{array}$ & 22.2 & 17.8 & 16.1 & 14.2 & 12.5 \\
\hline $\begin{array}{c}\text { Volume Treated } \\
(\%)\end{array}$ & 36.4 & 33.2 & 32.5 & 32 & 32.3 \\
\hline
\end{tabular}

The single and twin catch basin results are the same based on the inlet capacity curve (Figure 3-4) since because the water depth never reaches $0.06 \mathrm{~m}(6 \mathrm{~cm})$ and the difference between single and twin catch basins starts after $6 \mathrm{~cm}$ like horizontal bar/fishbone catch basin. In general, the results of grid catch basins are very similar to horizontal bar/fishbone catch basins. The peak runoff captured by inlet happens at the same time for 4-hour design storms as happens for the horizontal bar/fishbone catch basins. The outflow peak from bioretention cell for 4-hour design storms occurs after 7 hours for the 2-year storm and 8 hours for the 5-year storm and going backward for following design storms until approaches 6 hours for the 100-year storm. The peak flow from the bioretention cell is equal to 0.4817 for $10,25,100$ - year storms since the rate of percolation of soil reaches the hydraulic conductivity of the loamy sand soil. The volume treated percentage is the amount of stormwater that treated by the bioretention cell after 24 hours. The detention time increased like horizontal bar/fishbone catch basins and the system has still stormwater runoff after 24 hours.

\subsubsection{Scenario 4}

The inlets are single \& twin honeycomb catch basins for the 4-hour storms with $2,5,10,25,100$ year return periods. Figure 5-5 shows outlet, inlet \& bypass hydrographs for single \& twin horizontal bar/fishbone catch basins for 4 hours design storms. In addition, Table 5-7 defines results of the 4 hours design storms for scenario 4. 

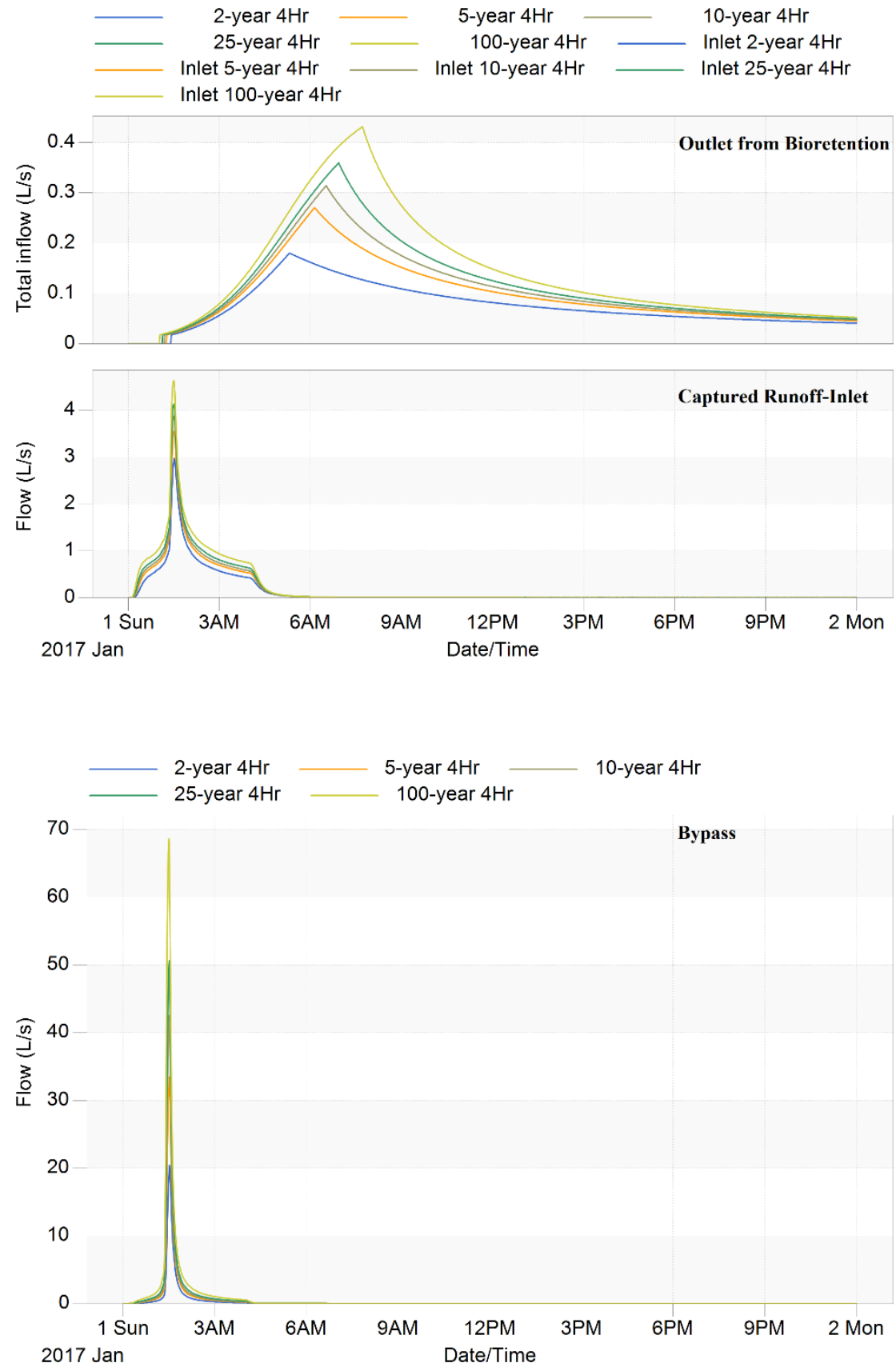

Figure 5-5: Outlet, Inlet $\&$ bypass hydrographs for single $\&$ twin honeycomb catch basins for 4 hours design storms. 
Table 5-7: Results of the 4 hours design storms for scenario 4.

\begin{tabular}{|c|c|c|c|c|c|}
\hline $\begin{array}{c}\text { Single \& twin } \\
\text { honeycomb } \\
\text { catch basins }\end{array}$ & $\begin{array}{c}2 \text {-year } \\
4 \mathrm{Hr}\end{array}$ & $\begin{array}{c}5-\text {-year } \\
4 \mathrm{Hr}\end{array}$ & $\begin{array}{c}10-\mathrm{year} \\
4 \mathrm{Hr}\end{array}$ & $\begin{array}{c}25-\mathrm{year} \\
4 \mathrm{Hr}\end{array}$ & $\begin{array}{c}100-\mathrm{year} \\
4 \mathrm{Hr}\end{array}$ \\
\hline $\begin{array}{c}\text { Peak Runoff } \\
\text { Reduction (\%) }\end{array}$ & 12.3 & 9.6 & 7.9 & 7.6 & 6.3 \\
\hline $\begin{array}{c}\text { Volume Treated } \\
(\%)\end{array}$ & 43.9 & 39.9 & 38.3 & 36.8 & 34.5 \\
\hline
\end{tabular}

The honeycomb catch basin has a higher capacity for capturing stormwater runoff comparing to horizontal bar \& grid catch basins. However, in the lower depths, the captured runoff is less than the other catch basins ranging from 3 to 4.5 1/s. The results for both single and twin catch basin are equal like previous scenarios considering inlet capacity curve (Figure 3-4) since the water depth never reaches $0.06 \mathrm{~m}(6 \mathrm{~cm})$ and the difference between single and twin catch basins start after $6 \mathrm{~cm}$. The peak runoff captured by inlet happens after almost 90 minutes for 4-hour design storms. After 5 hours, the outflow peak from the bioretention cell for 4-hour design storms for the 2 -year occurs and gradually moving forward to 8 hours for the 100-year storm. The peak outflows for 4-hour storm are ranging from 0.15 to $0.451 / \mathrm{s}$. The volume treated percentage is the amount of stormwater that treated by the bioretention cell after 24 hours. After 24 hours stormwater runoff remains in the bioretention cell for 4-hour storm which means the detention time is increased compared to system without LID.

\subsubsection{Scenario 5}

The inlet is curb opening with a 0.5 -meter opening for the 4-hour storms with 2,5,10,25,100- year return periods. Figure 5-6 displays outlet, inlet \& bypass hydrographs for single \& twin horizontal bar/fishbone catch basins for 4 hours design storms. Also, Table 5-8 describes results of the 4 hours design storms for scenario 5. 

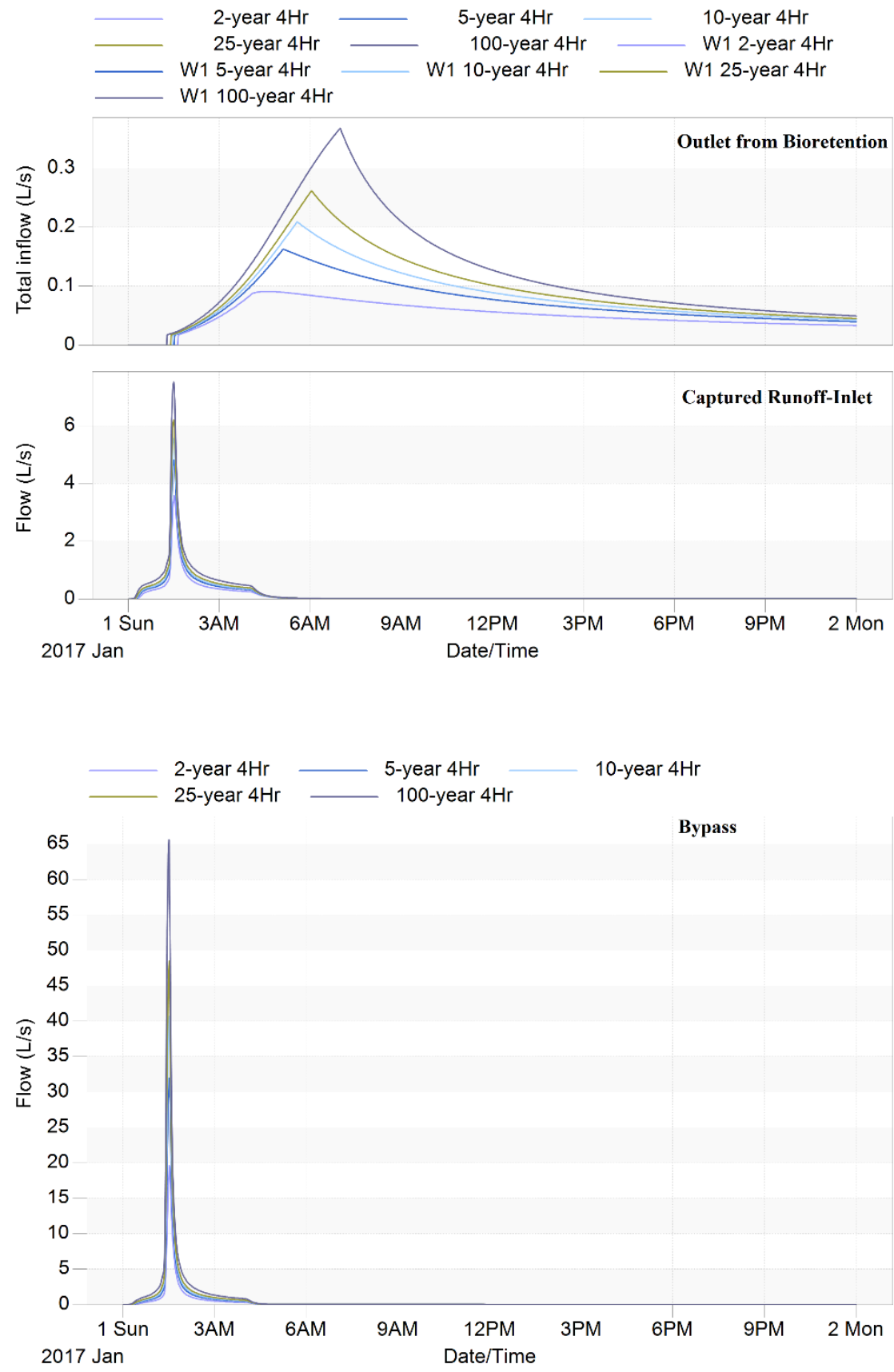

Figure 5-6: Outlet, Inlet \& bypass hydrographs for curb opening for 4 hours design storms. 
Table 5-8: Results of the 4 hours design storms for scenario 5.

\begin{tabular}{|c|c|c|c|c|c|}
\hline Curb opening & $\begin{array}{c}2 \text {-year } \\
4 \mathrm{Hr}\end{array}$ & $\begin{array}{c}5 \text {-year } \\
4 \mathrm{Hr}\end{array}$ & $\begin{array}{c}10 \text {-year } \\
4 \mathrm{Hr}\end{array}$ & $\begin{array}{c}25 \text {-year } \\
4 \mathrm{Hr}\end{array}$ & $\begin{array}{c}100 \text {-year } \\
4 \mathrm{Hr}\end{array}$ \\
\hline $\begin{array}{c}\text { Peak Runoff } \\
\text { Reduction (\%) }\end{array}$ & 15.5 & 12 & 11.3 & 11.2 & 9 \\
\hline $\begin{array}{c}\text { Volume } \\
\text { Reduction (\%) }\end{array}$ & 49.5 & 44.9 & 42.7 & 40.5 & 36.9 \\
\hline
\end{tabular}

The captured stormwater runoff for this scenario is less than previous scenarios and it is ranging from 3.5 to $7.5 \mathrm{l} / \mathrm{s}$ compared to 6 to $10 \mathrm{l} / \mathrm{s}$. The amount of captured stormwater runoff is based on length of the curb opening which 0.5 meters in this scenario. The peak runoff captured by inlet happens after almost 90 minutes for 4-hour design storms. The outflow peak from the bioretention cell for 4-hour design storms happens after 5 hours for the 2-year storm and constantly occurs later for following design storms until reaches 8 hours for the 100-year storm. The volume treated percentage is the amount of stormwater that treated by the bioretention cell after 24 hours. For all the design storms, the system has stormwater runoff inside the cell after 24 hours which means more detention time compared to conventional stormwater practices.

\subsubsection{Scenario 6}

The inlet is curb cut with a 0.5 -meter opening for the 4-hour storms with 2,5,10,25,100- year return periods. The conventional bioretention cell was used for this scenario and has 4 inches (101.6mm) of mulch as a surface layer. It also has direct rainfall on the surface of the bioretention cell. Figure 5-7 illustrates outlet, inlet \& bypass hydrographs for single \& twin horizontal bar/fishbone catch basins for 4 hours design storms. Also, Table 5-9 defines results of the 4 hours design storms for scenario 6 . 

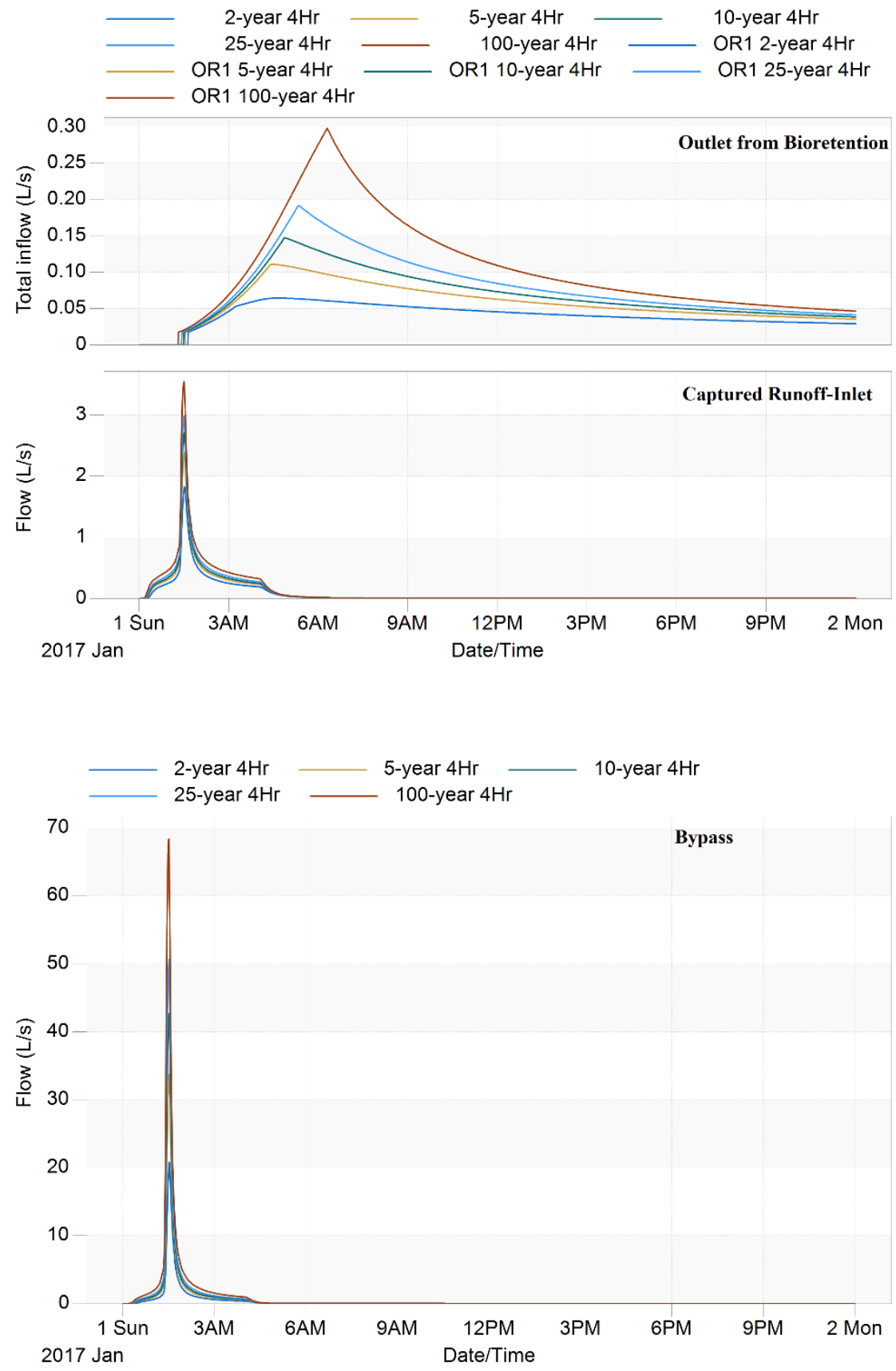

Figure 5-7: Outlet, Inlet \& bypass hydrographs for curb cut for 4 hours design storms. 
Table 5-9: Results of the 4 hours design storms for scenario 6.

\begin{tabular}{|c|c|c|c|c|c|}
\hline Curb cut & $\begin{array}{c}2 \text {-year } \\
4 \mathrm{Hr}\end{array}$ & $\begin{array}{c}5 \text {-year } \\
4 \mathrm{Hr}\end{array}$ & $\begin{array}{c}10 \text {-year } \\
4 \mathrm{Hr}\end{array}$ & $\begin{array}{c}25 \text {-year } \\
4 \mathrm{Hr}\end{array}$ & $\begin{array}{c}100 \text {-year } \\
4 \mathrm{Hr}\end{array}$ \\
\hline $\begin{array}{c}\text { Peak Runoff } \\
\text { Reduction }(\%)\end{array}$ & 8.2 & 6.2 & 5.5 & 5.3 & 5 \\
\hline $\begin{array}{c}\text { Volume Treated } \\
(\%)\end{array}$ & 37.3 & 28.9 & 23.9 & 18.8 & 8.8 \\
\hline
\end{tabular}

The captured stormwater runoff for curb cut is less than curb opening scenario and it is ranging from 1.8 to $3.5 \mathrm{l} / \mathrm{s}$. The amount of captured stormwater runoff is based on length of the curb cut which 0.5 meters in this scenario and the location of the curb cut. In addition, the conventional bioretention with a surface layer is used for this scenario and it has direct rainfall on the surface of the bioretention cell, but the results are almost the same since the area of bioretention is only $57.856 \mathrm{~m}^{2}$. The peak runoff captured by inlet happens for 4-hour design storms occurs at same time as scenario 5. The outflow peak from the bioretention cell for 4-hour design storms happens after 5 hours for the 2-year storm and constantly occurs later for following design storms until reaches 7 hours for the 100-year storm. The volume treated percentage is the amount of stormwater that treated by the bioretention cell after 24 hours. For all design storms, the system has stormwater runoff inside the cell after 24 hours which means more detention time compared to conventional stormwater practices.

\subsection{Comparison of scenarios}

By comparing captured stormwater runoff, peak flow reduction, detention time, and volume treated among different scenarios for 4-hour design storms. We found out that scenario 1 (single \& twin horizontal bar/fishbone catch basins) is the best choice since it has highest captured stormwater runoff (6-10 1/s), detention time, and peak flow reduction according to the captured stormwater runoff. Scenario 2 (OPSD400.01) and scenario 3 (grid catch basin) are very similar to scenario 1 except they can capture lower flows. Scenario 4 (honeycomb catch basin) is suitable for the bigger catchment areas with the higher flow. The performance of scenario 5 (curb opening) and scenario 6 (curb cut) are not very satisfactory since the amount of captured stormwater runoff is very limited. However, the amount of captured stormwater runoff is based on the opening and number of inlets for scenario 5\&6. Comparison of scenarios shown below in Figure 5-8: 


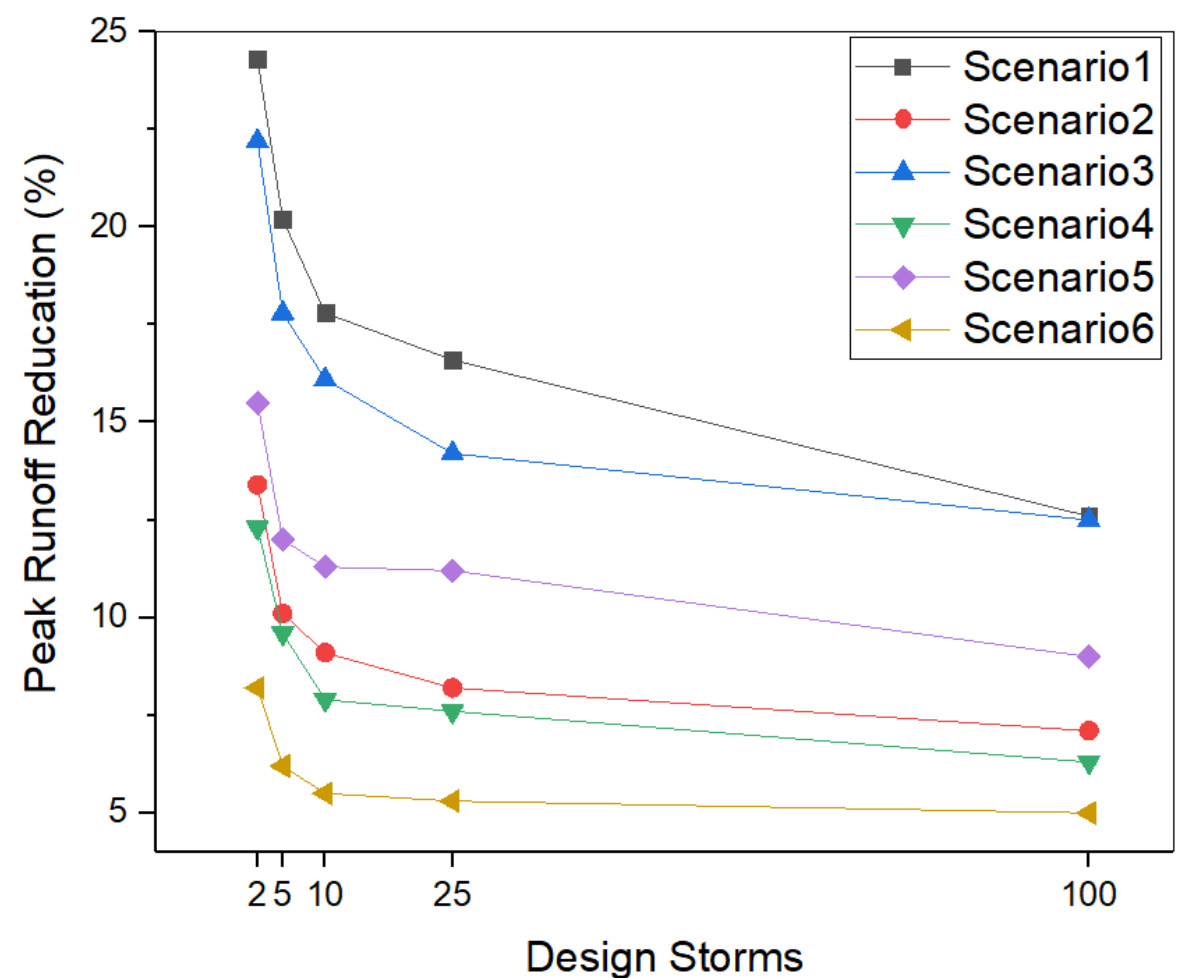

Figure 5-8: Comparison of Scenarios.

\subsection{Sensitivity analysis}

Sensitivity analysis conducted by sensitivity analysis tool in PCSWMM. Uncertainty parameters were defined before doing sensitivity analysis. Subcatchment area and slope from subcatchments, length and elevation form conduits, elevation form junctions, and bioretention cell layers parameters were selected for sensitivity analysis. Scenario 1 (single \& twin horizontal bar/fishbone catch basins) with 5-year design storm is used for sensitivity analysis and the peak outflow from bioretention cell is calculated for uncertainty parameters from $-30 \%$ to $30 \%$ for each parameter. The results demonstrated that the subcatchment area has the most impact on the peak outflow from bioretention cell while the rest of uncertainty parameters don't have a significant effect on the peak outflow from the bioretention cell. 


\subsection{FLOW-3D Results}

\subsubsection{Initial model}

As mentioned in Chapter 3, two scenarios were investigated by FLOW-3D. The 6 inches (150mm) perforated pipe with the length of $6.5 \mathrm{~m}, 4$ perforations at the bottom of the pipe with the size of $25 \mathrm{~mm} \times 2.5 \mathrm{~mm}$ for each perforation and distance of $1.5 \mathrm{~m}(1.5 \mathrm{~m}, 3 \mathrm{~m}, 4.5 \mathrm{~m}, 6 \mathrm{~m})$ between each perforation investigated as an initial scenario and for simplicity of the modeling. A set of experiments with 5 different flows $(0.63 \mathrm{~L} / \mathrm{s}, 1.01 \mathrm{~L} / \mathrm{s}, 2.02 \mathrm{~L} / \mathrm{s}, 8.08 \mathrm{~L} / \mathrm{s}, 10.28 \mathrm{~L} / \mathrm{s})$ was conducted by another Ryerson graduate student (Lianghao Chen) with uniform flows and steady-state conditions. The length of the perforated pipe in the lab is $6.5 \mathrm{~m}$ and has 275 set of perforations and each set has 4 perforations with the size of $25 \mathrm{~mm} \times 0.5 \mathrm{~mm}$. The size of perforations is increased to $50 \mathrm{~mm} \times 50 \mathrm{~mm}$ in FLOW-3D initial model and the total area of the perforations in the FLOW$3 \mathrm{D}$ model and the experimental condition is almost equal.

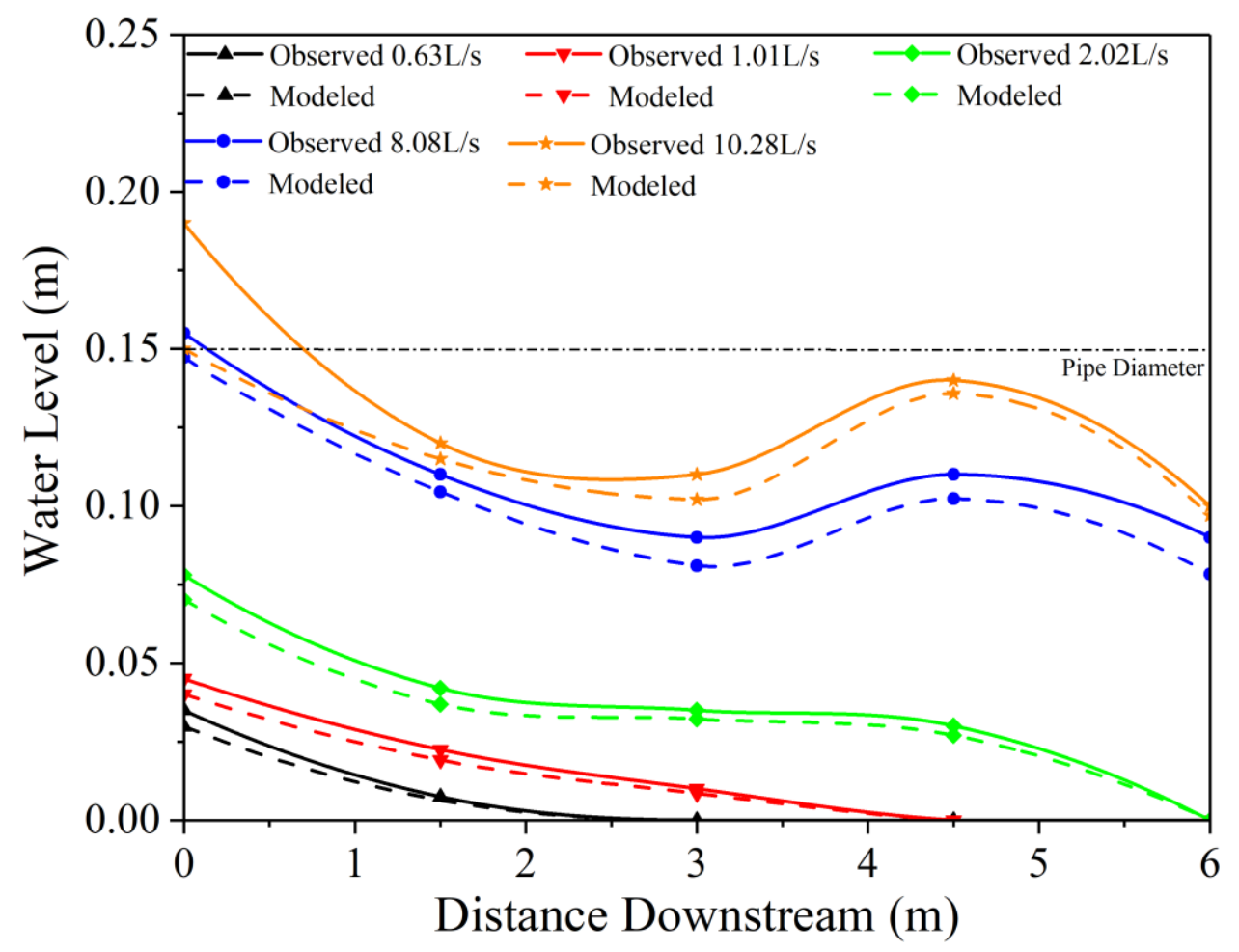

Figure 5-9: Comparison of the FLOW-3D with experimental results.

The performance of the FLOW-3D model is examined by comparing the results of the FLOW-3D modeling and observed data for validating \& adjusting the model in Figure 5-9 shown above. 
Figure 5-9 demonstrated that the average error is $10-15 \%$ between FLOW-3D \& observed data which is reasonable. The final FLOW-3D model for $18 \mathrm{~m}$ perforated pipe is studied in the next subchapter considering the initial model procedure. Figure 5-10 shown below the FLOW-3D model for $2.02 \mathrm{~L} / \mathrm{s}$.

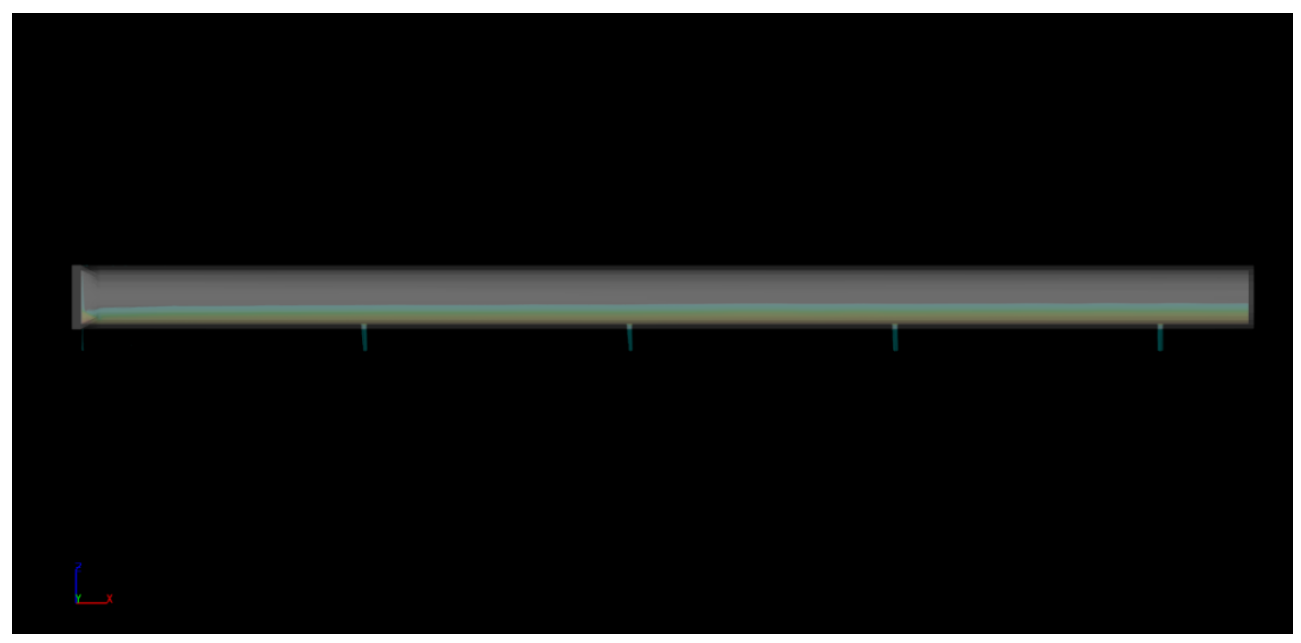

Figure 5-10: FLOW-3D Model for 2.02 L/s.

\subsubsection{Final model}

The final model in FLOW-3D is based on the perforated distribution pipe on top of the bioretention cell. The length of the perforated pipe in the model is $18 \mathrm{~m}$ according to the length of the bioretention cell. Therefore, a 6 inches $(150 \mathrm{~mm})$ perforated pipe with the length of $18 \mathrm{~m}$ was selected. The diameter of the perforations is $10 \mathrm{~mm}$ and the distance between perforations along the pipe is $0.9 \mathrm{~m}$. The model has 19 set perforations and each set has 4 perforations on the crosssection of the pipe with the $45^{\circ}\left(135^{\circ}\right)$ angle. The total number of perforations in this model is 76 . The captured stormwater runoff from the inlet in scenario 1 to scenario 6 was almost ranging between 2 to $10 \mathrm{~L} / \mathrm{s}$. 5 different flows $(2,4,6,8 \& 10 \mathrm{~L} / \mathrm{s})$ were selected to use as input for the FLOW-3D model. Figure 5-11 shows velocity vectors for $2 \mathrm{~L} / \mathrm{s}$ model from a set of perforations: 


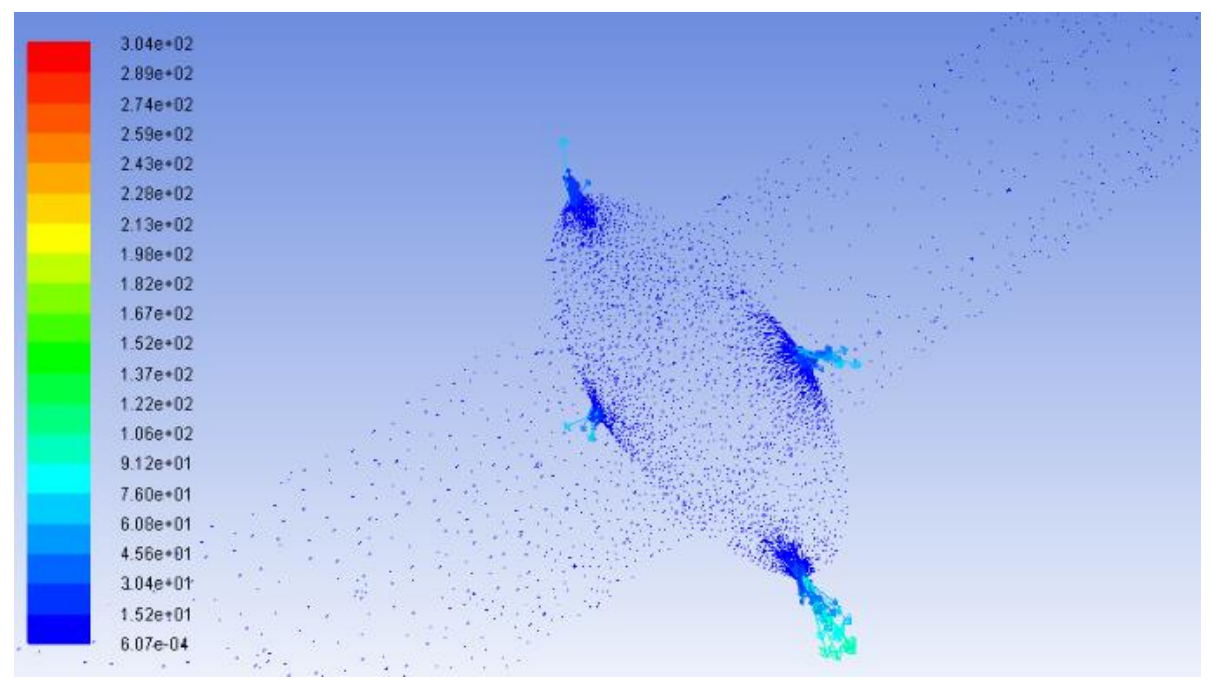

Figure 5-11: velocity vectors for $2 \mathrm{~L} / \mathrm{s}$ model.

The percentage of utilization of the perforated pipe can be obtained by running the model for the five different flows in steady-state conditions and plotting the water profiles vs the length of the perforated pipe. The percentage of the perforated pipe that utilized is equivalent to the percentage of utilization of the bioretention cell since the length of the perforated pipe on the top of the bioretention cell is equal to the length of the bioretention cell. Figure 5-12 shown below 5 different water profiles vs length of the bioretention cell (perforated pipe).

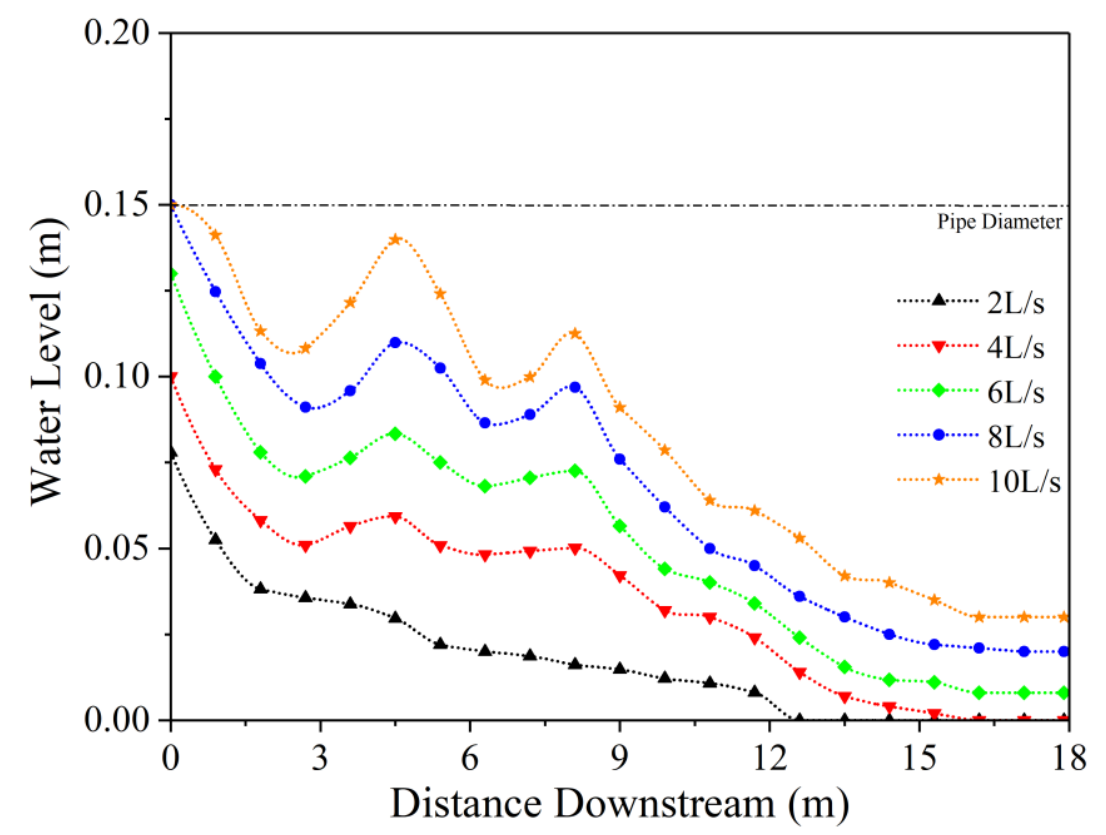

Figure 5-12: Water profiles for different flows modeled with FLOW-3D.

According to Figure 5-12, the bioretention cell is not fully used for $2 \mathrm{~L} / \mathrm{s}$. The stormwater runoff only reached to pore 14 which is $14 \times 0.9=12.6 \mathrm{~m}$ out the $18 \mathrm{~m}$ length of the bioretention cell. In 
addition, only $16.2 \mathrm{~m}$ out $18 \mathrm{~m}$ of the bioretention cell is utilized for $4 \mathrm{~L} / \mathrm{s}$ which is pore 18 $(18 \times 0.9=16.2 \mathrm{~m})$. The bioretention cell is fully utilized for $6,8 \& 10 \mathrm{~L} / \mathrm{s}$ since the stormwater runoff reached to the end of the perforated pipe. The reduction scale is $33.3 \%$ for $2 \mathrm{~L} / \mathrm{s}$ and $11.1 \%$ for 4 $\mathrm{L} / \mathrm{s}$. The new sizing of the bioretention cell is $12 \mathrm{~m}$ length and the area of $38 \mathrm{~m}^{2}$ and $16 \mathrm{~m}$ length and the area $50 \mathrm{~m}^{2}$ since bioretention is the part of the minor system that only designed for 2-year storm and some of the captured stormwater runoff in scenario 1 to 6 were between 2 to $4 \mathrm{~L} / \mathrm{s}$. Therefore, the performance of the bioretention cell with 2 new sizing is investigated for scenario 1 in the next section. Figure 5-13 exhibits $18 \mathrm{~m}$ perforated pipe for $6 \mathrm{~L} / \mathrm{s}$ model:

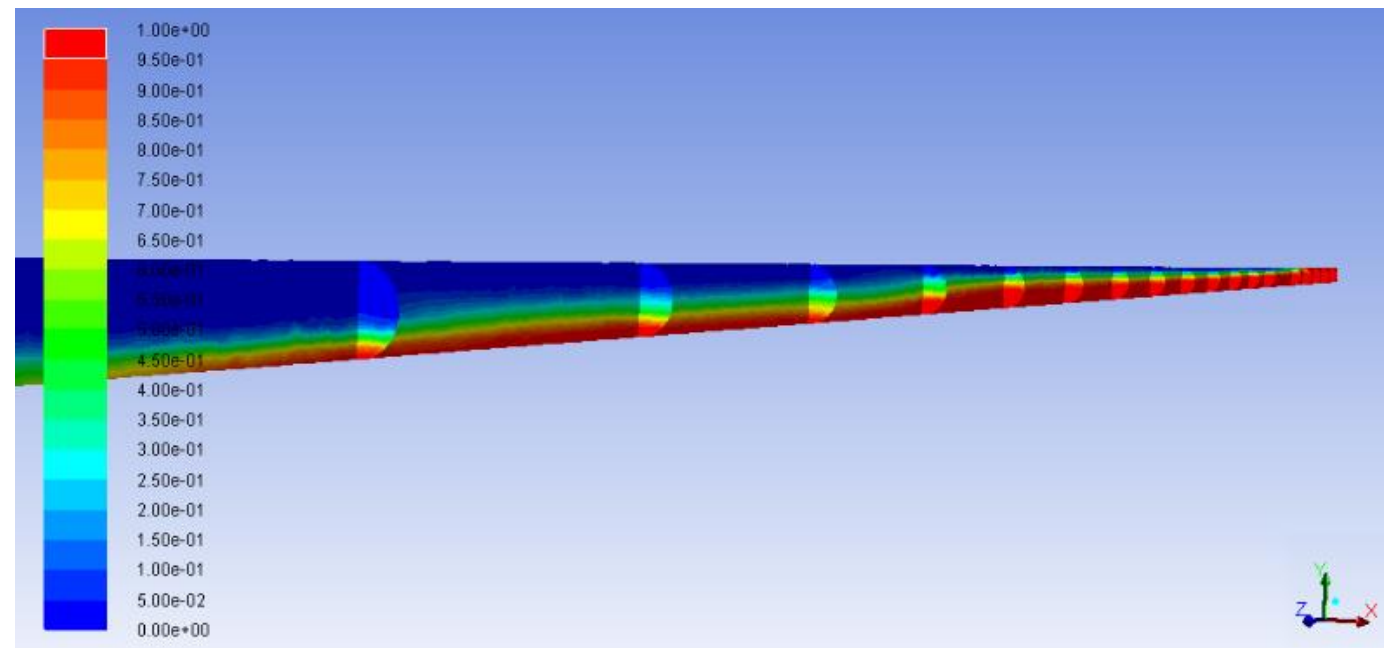

Figure 5-13:18m perforated pipe for $6 \mathrm{~L} / \mathrm{s}$ model.

\subsection{Performance of the bioretention cell with new sizing}

\subsubsection{2m Bioretention cell}

As mentioned in scenario 1 , the inlets are single $\&$ twin horizontal bar/fishbone catch basins. This time only 4-hour storms 2,5,10,25,100- year return periods were investigated. Figure 5-14 dementated below outlet, Inlet \& bypass hydrographs for 4-hour design storms with $12 \mathrm{~m}$ length and the area of $38 \mathrm{~m}^{2}$ of the bioretention cell and Table 5-10 explains the results of the 4 hours design storms for $12 \mathrm{~m}$ bioretention cell: 

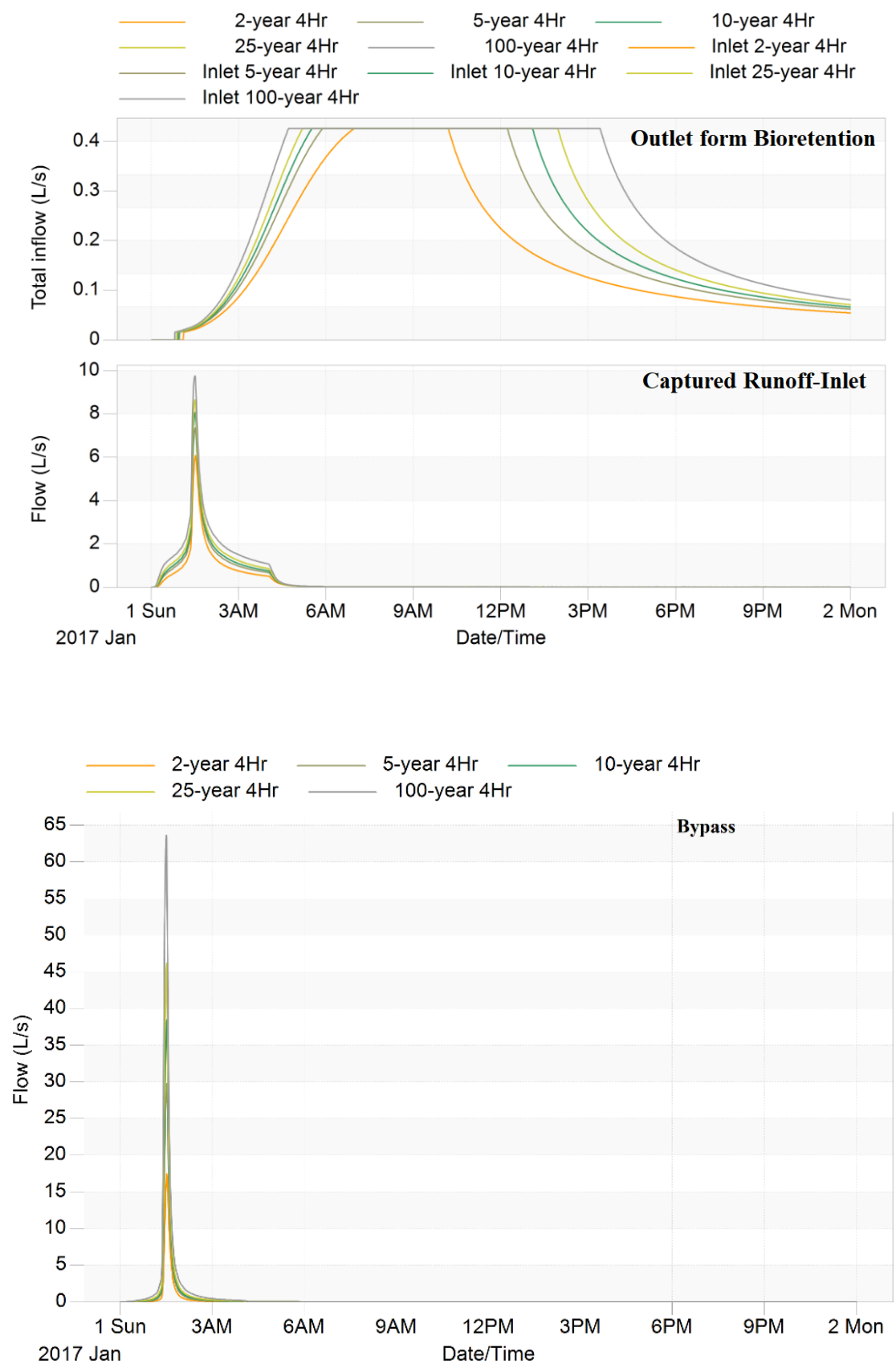

Figure 5-14: Outlet, Inlet \& bypass hydrographs for single \& twin horizontal bar/fishbone catch basins for 4 hours design storms for $12 \mathrm{~m}$ bioretention cell. 
Table 5-10: Results of the 4 hours design storms for $12 \mathrm{~m}$ bioretention cell.

\begin{tabular}{|c|c|c|c|c|c|}
\hline $\begin{array}{c}\text { Single \& twin } \\
\text { horizontal } \\
\text { bar/fishbone } \\
\text { catch basins }\end{array}$ & $\begin{array}{c}2 \text {-year } \\
4 \mathrm{Hr}\end{array}$ & $\begin{array}{c}5-\mathrm{year} \\
4 \mathrm{Hr}\end{array}$ & $\begin{array}{c}10 \text {-year } \\
4 \mathrm{Hr}\end{array}$ & $\begin{array}{c}25 \text {-year } \\
4 \mathrm{Hr}\end{array}$ & $\begin{array}{c}100 \text {-year } \\
4 \mathrm{Hr}\end{array}$ \\
\hline $\begin{array}{c}\text { Peak Runoff } \\
\text { Reduction (\%) }\end{array}$ & 26 & 20.9 & 18.8 & 17.9 & 13.9 \\
\hline $\begin{array}{c}\text { Volume Treated } \\
(\%)\end{array}$ & 30.7 & 28.5 & 25.7 & 23.6 & 21 \\
\hline
\end{tabular}

The water depth is always less than $0.06 \mathrm{~m}(6 \mathrm{~cm})$ and the results for both single and twin catch basin are the same considering inlet capacity curve (Figure 3-4). The outflow peak from bioretention cell occurs almost after 7 hours for the 2-year storm while for 100-year storm happens after 4 hours. The peak outflow from the bioretention cell for all design storm is equal to 0.4913 $\mathrm{L} / \mathrm{s}$ since the rate of percolation of soil reaches the hydraulic conductivity of the loamy sand soil which is $29.97 \mathrm{~mm} / \mathrm{hr}$ and the area of the bioretention cell is smaller than the original area of the bioretention cell. The peak runoff increases for all design storms and the peak runoff reduction percentage decreased $0.7-1.7 \%$ for different return periods even due to the smaller area and volume since bioretention can be considered as unit storage with less volume. The volume treated percentage reduced between 5-12\% for different return periods. The detention time decreased for all design storms due to the less stormwater runoff that smaller bioretention cell can hold. The excavation and construction cost are reduced since the area of the bioretention cell is shrunken by $33 \%$ and it can save a lot of money for the development of a LID project.

\subsubsection{6m Bioretention cell}

The $16 \mathrm{~m}$ bioretention cell with the area of $50 \mathrm{~m}^{2}$ is examined and the results compared with the original bioretention cell. The inlets are single \& twin horizontal bar/fishbone catch basins with again 4-hour design storm with 2,5,10,25,100- year return periods. Figure 5-15 shown below outlet, Inlet \& bypass hydrographs for 4-hour design storms with $16 \mathrm{~m}$ length and the area of 50 $\mathrm{m}^{2}$ of the bioretention cell and Table 5-11 describes the results of the 4 hours design storms for $12 \mathrm{~m}$ bioretention cell: 

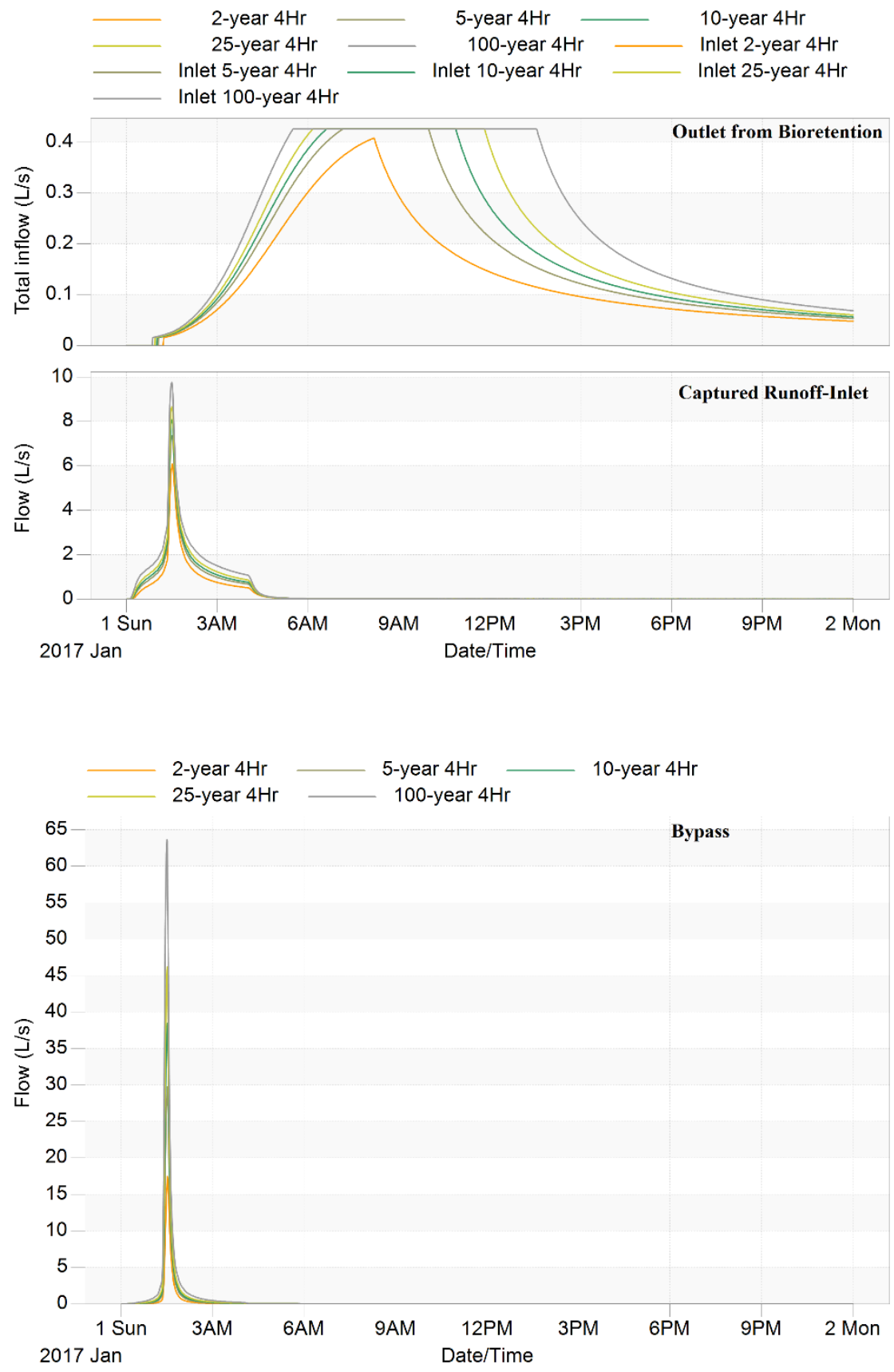

Figure 5-15: Outlet, Inlet \& bypass hydrographs for single \& twin horizontal bar/fishbone catch basins for 4 hours design storms for $16 \mathrm{~m}$ bioretention cell. 
Table 5-11: Results of the 4 hours design storms for $16 \mathrm{~m}$ bioretention cell.

\begin{tabular}{|c|c|c|c|c|c|}
\hline $\begin{array}{c}\text { Single \& twin } \\
\text { horizontal } \\
\text { bar/fishbone } \\
\text { catch basins }\end{array}$ & $\begin{array}{c}2 \text {-year } \\
4 \mathrm{Hr}\end{array}$ & $\begin{array}{c}5-\text {-year } \\
4 \mathrm{Hr}\end{array}$ & $\begin{array}{c}10-\text { year } \\
4 \mathrm{Hr}\end{array}$ & $\begin{array}{c}25 \text {-year } \\
4 \mathrm{Hr}\end{array}$ & $\begin{array}{c}100 \text {-year } \\
4 \mathrm{Hr}\end{array}$ \\
\hline $\begin{array}{c}\text { Peak Runoff } \\
\text { Reduction (\%) }\end{array}$ & 24.8 & 20.9 & 18.5 & 17.3 & 13.3 \\
\hline $\begin{array}{c}\text { Volume Treated } \\
(\%)\end{array}$ & 34.5 & 32.9 & 33 & 33.4 & 35.4 \\
\hline
\end{tabular}

The results for both single and twin catch basin are the same considering inlet capacity curve (Figure 3-4) and the water depth never reaches $0.06 \mathrm{~m}(6 \mathrm{~cm})$. The outflow peak from bioretention cell happens almost after 7 hours for the 2-year storm while for 100-year storm occurs after 4 hours. The peak outflow from the bioretention cell for the 2-year storm is equal to $0.4131 \mathrm{~L} / \mathrm{s}$. Moreover, the peak outflow from the bioretention cell for 4 hours after the 2-year storm equals $0.485 \mathrm{~L} / \mathrm{s}$ since the rate of percolation of soil reaches the hydraulic conductivity of the loamy sand soil which is $29.97 \mathrm{~mm} / \mathrm{hr}$ and the area of the bioretention cell is smaller than the original area of the bioretention cell. The peak runoff fairly increases for all design storms and the peak runoff reduction is reduced only $0.7 \%$ for different return periods except for the 2-year storm and the difference between the area of the original bioretention is only $7 \mathrm{~m}^{2}$. The volume reduction percentage is almost the same for different return periods comparing to the original bioretention cell. The detention time decreased for all design storms due to the less stormwater runoff that smaller bioretention cell can hold.

\subsubsection{Comparison of $100 \%, 88 \% \& 67 \%$ bioretention cell}

After finding the effective length of the bioretention cell which is the percentage of the bioretention that utilized. Figure 5-16 to 5-18 demonstrated below the performance of the $100 \%, 88 \% \& 67 \%$ bioretention cell for 2,5,10-year design storms. The captured inflow runoff from the catch basin occurs after 90 minutes with high peak flows compared to the outflow peaks. The peak runoff from the bioretention cell is increased for $67 \%$ \& $88 \%$ (area of bioretention cell) compared to the peak runoff from original bioretention cell. 

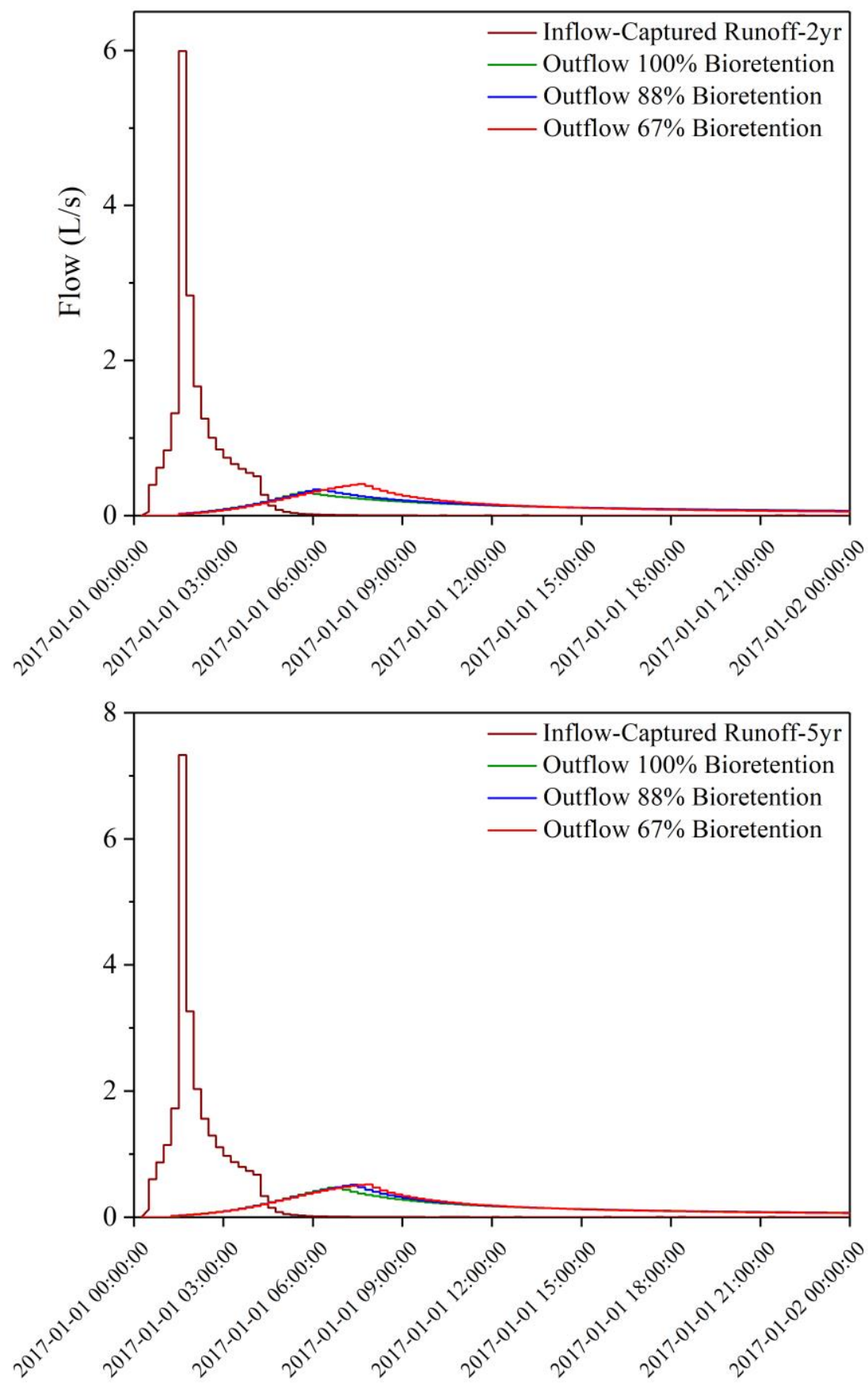


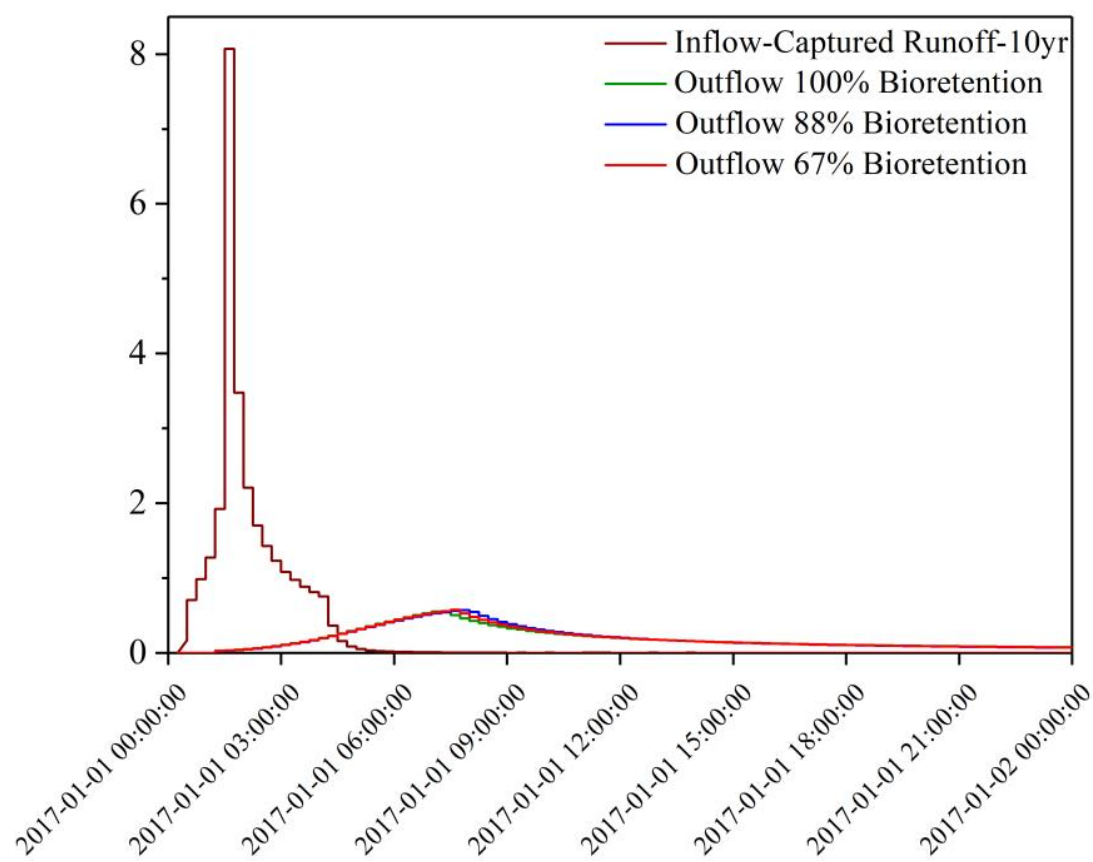

Figure 5-16,5-17,5-18: The performance of 100,88,67\% bioretention cell for different return periods. The comparison between 100,88, 67\% bioretention cell represents the overestimate design of the bioretention cell. The FLOW-3D results showed us after $6 \mathrm{~L} / \mathrm{s}$ the perforation pipe was fully utilized and $12 \mathrm{~m} \mathrm{\&} 16 \mathrm{~m}$ are the effective lengths of the bioretention cell. Therefore, the hydrographs for the inflow and the outflow from the bioretention were examined again. If the captured runoff equals $6 \mathrm{~L} / \mathrm{s}$ or less, the outflow hydrographs will use the results of $67 \%$ bioretention cell and for more than $6 \mathrm{~L} / \mathrm{s} 100 \%$ bioretention cell results will utilize. Figure 5-19 to 5-23 shown below modified inflow \& outflow hydrographs for 2,5,10,25 \&100-year design storms. 

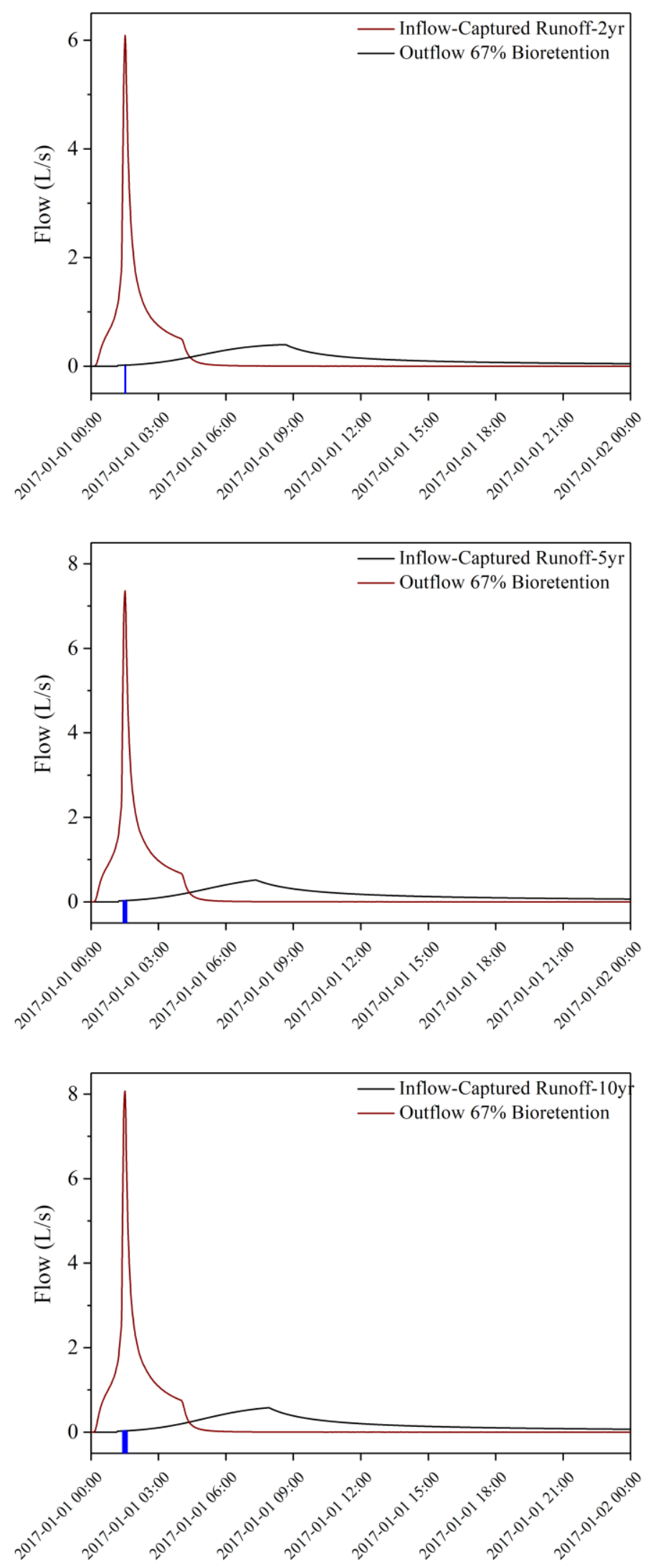

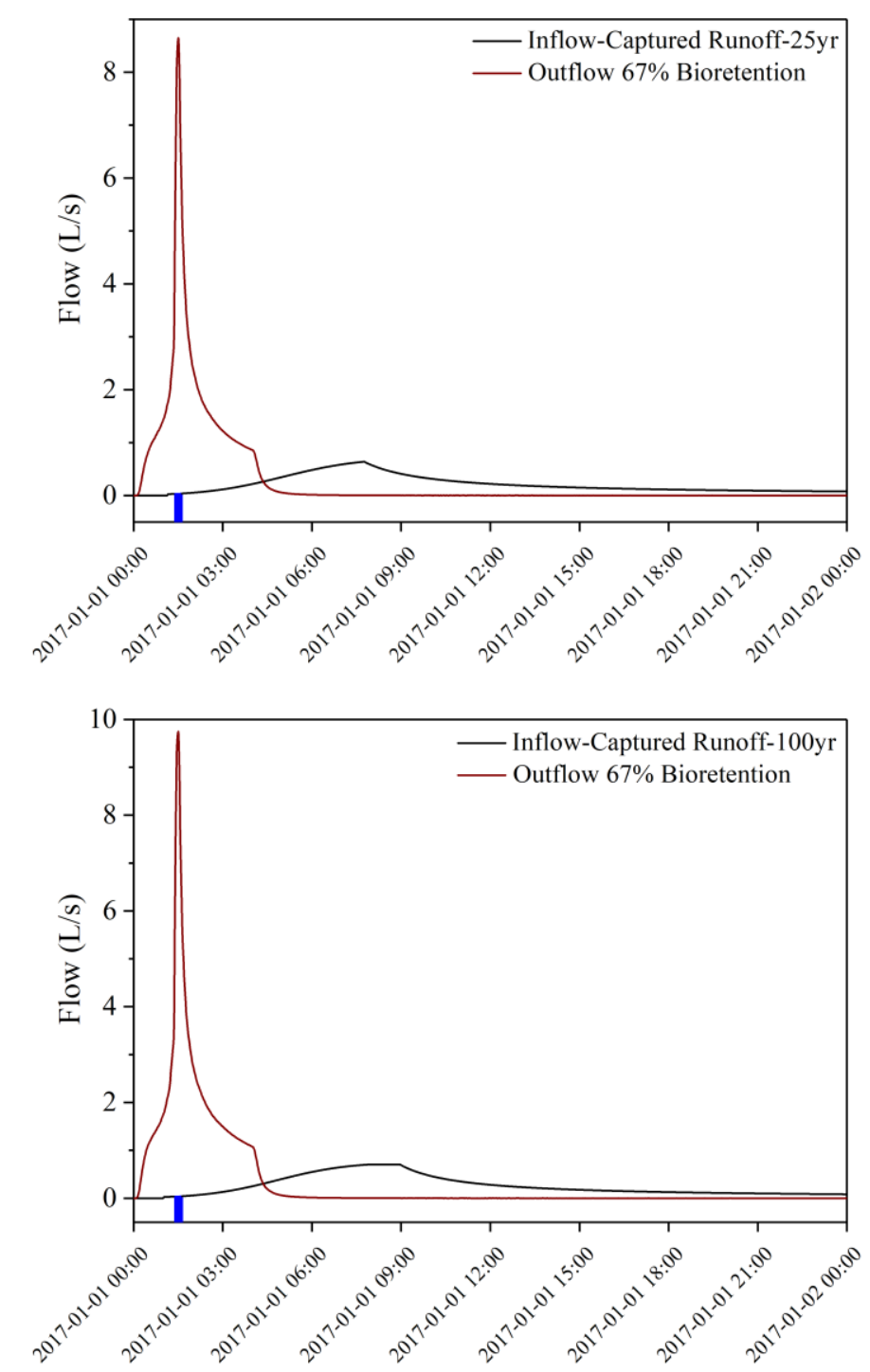

Figure 5-19,5-20,5-21,5-22,5-23: The modified inflow \& outflow hydrographs for different design storms.

According to the above figures, the blue column is the time that $100 \%$ bioretention cell was utilized instead of $67 \%$ which always occurred around 90 minutes (at the time of the captured inflow peaks). For the 2-year storm, the captured inflow only surpassed 6 L/s in 2 times in 24 hours while for the 100-year storm, the captured inflow exceeded $6 \mathrm{~L} / \mathrm{s}$ for 14 times in 24 hours. We can clearly state that $90 \%$ of the outflow hydrographs are satisfied with $67 \%$ bioretention cell and at the peaks of captured inflow $100 \%$ bioretention cell results were used. 


\subsection{Performance of the bioretention cell in continues simulation}

The performance of the bioretention cell is examined for continues simulation regarding the effective length of the bioretention cell for $100,88 \& 67 \%$ of the bioretention cell area. The rainfall data from a rain gage in GTA (Richmond Hill) was used for the whole year of 2011 for this simulation. The hydrologic budget or water balance only consists of runoff component since the bioretention cell is underneath the sidewalk and it has no evapotranspiration and infiltration to the native soil. Table 5-12 shown below the water balance in liter for the year 2011 for $100,88 \& 67 \%$ of the bioretention cell area.

Table 5-12: Performance of bioretention cell in continues simulation

\begin{tabular}{|c|c|c|c|}
\hline & $\mathbf{1 0 0 \%}$ Bioretention & $\mathbf{8 8 \%}$ Bioretention & 67\% Bioretention \\
\hline Catch basin Bypass & 2204 & 2204 & 2204 \\
\hline Underdrain & 93010 & 92620 & 92390 \\
\hline Surface Runoff & 2.839 & 5.201 & 26.26 \\
\hline Total & 95216.839 & 94829.201 & 94620.26 \\
\hline
\end{tabular}

The catch basin bypass flows are the same for three bioretention areas while the underdrain flows from the bioretention cell for original bioretention cell is larger than the other ones. The surface runoff for this project is equivalent to bypass from bioretention cell or overflow pipe on the top of the bioretention cell. When the storage on the top of the bioretention cell is exceeded in the real condition, the stormwater runoff cannot discharge from the perforations and runoff backup from the perforated pipe to the catch basin. 


\section{Chapter 6 Conclusions and Recommendations}

\subsection{Conclusions}

Bioretention is one of the most prominent LID practices that can mimic the natural hydrological cycle. In addition, bioretention is one the important LID practices that works very efficient in the urbanized area in both water quality and quantity in small catchment areas. The modeling of a bioretention cell with different scenarios is the main objective of this research. The conclusions are based on several investigations on the performance of a bioretention facility stated below.

Six different scenarios of the inlet configurations with 2,5,10,25 \&100-year design storms were investigated with a SWMM model in PCSWMM software. The inlet, outlet, and bypass hydrographs plotted and the performance of the bioretention cell which is the peak runoff reduction $\&$ volume reduction percentage were examined. It was found that scenario 1 (single \& twin horizontal bar/fishbone catch basins) had the best performance among other scenarios. In addition, sensitivity analysis showed that the catchment area \& bioretention area has the most impact on the peak outflow from the bioretention cell. The perforated distribution pipe examined with FLOW3D with an initial and final model for finding new design and sizing of the bioretention cell. The utilization of the bioretention cell (perforated pipe) found by FLOW-3D model using the effective length of bioretention cell and showed that for $2 \& 4 \mathrm{~L} / \mathrm{s}$ only 12 and $16 \mathrm{~m}$ of the bioretention cell utilized. The performance of the bioretention reinvestigated again for $100,88 \& 67 \%$ of the bioretention area and the results demonstrated the peak runoff increased for $67 \%$ by 0.7 to $1.7 \%$ while for $88 \%$ of the bioretention is only $0.7 \%$. The smaller bioretention cell can hold less stormwater runoff due to smaller volume and less amount of soil. Finally, bioretention is a smallscale treatment facility that can be scale up if has a proper water distribution.

One of the objectives of this research is synthesizing numerical results into recommendations for a better design of the bioretention facility. After reviewing all results and changes and modification, some recommendations for a better design of the bioretention facility were proposed in the following subchapter. 


\subsection{Recommendations}

After finding the effective length of the bioretention cell and investigating the performance of the bioretention facility, we can clearly state that the volumetric design is not a proper way to build a bioretention facility. Some design recommendations for having a proper water distribution over the bioretention cell and improving the performance of the bioretention facility were proposed below:

- Using a straight PVC pipe as a perforated distribution pipe instead of a corrugated pipe for not trapping stormwater runoff and solving the backwater issue.

- The number of perforations, the distance between perforations, and the orientation of perforations have a huge impact on the water distribution in the perforated pipe. It's recommended that to use a series of perforations with a various distance between perforations especially in the second half of the perforated pipe. In that way, we may have a better water distribution with a lower flow throughout the perforation pipe and the full length of the perforated pipe will utilize.

- Selection of the effective inlet configurations considering the slope of the road and having the most captured runoff among the inlet configurations is another recommendation for improving the performance of the bioretention facility. Also, the optimal location of the inlet is important since it has a significant effect on the water distribution throughout the whole system.

- Scheduled maintenance for cleaning the catch basin (dead storage), distribution pipe \& outflow must be followed in a regular basis.

- The soil percolation rate reaches hydraulic conductivity of soil and it's a barrier for capturing more runoff into the bioretention facility. However, it is very beneficial for increasing the detention time.

- It's a recommended that to use a series of the connected bioretention for having a more effective system.

- The performance of the bioretention facility in terms of water quality is very desirable. It's recommended that to connect the bioretention facility to the native soil if the groundwater level is not high. Therefore, the infiltration changes the water balance and the performance of the bioretention will improve by capturing more stormwater runoff into the system. 
The performance of a bioretention facility was investigated in this research. However, here are some suggestions for further research on the modeling of bioretention facilities:

- Modeling a series of bioretention facilities like the Six Point project in Dundas West Street in the City of Toronto with some reliable observed data.

- Finding the optimal location of the inlet for the curb cut scenario and modeling the surface water with DRAINMODE or MODFLOW.

- Modeling a bioretention facility in a highly urbanized area like the downtown core of the City of Toronto.

- 3D modeling of a bioretention facility with HYDRUS 2D/3D. 


\section{Nomenclature}

$\begin{array}{ll}\text { A } & \text { catchment area (ha) } \\ \text { C } & \text { Runoff coefficient } \\ \mathrm{C}_{\mathrm{W}} & \text { Discharge coefficient } \\ \mathrm{d} & \text { Water depth } \\ \mathrm{e} & \text { Evapotranspiration } \\ \mathrm{f} & \text { Infiltration or soil percolation } \\ \mathrm{f} & \text { Void ratio } \\ \mathrm{h} & \text { head difference across the weir } \\ i & \text { Rain Intensity (mm/hr) } \\ \mathrm{K}_{\mathrm{f}} & \text { Conversion Factor } \\ \mathrm{L} & \text { Weir length } \\ \mathrm{q} & \text { Flow rate } \\ \mathrm{q} & \text { Moisture content } \\ \mathrm{Q}_{\mathrm{s}} & \text { Side Flow of Inlet } \\ \mathrm{Q}_{\mathrm{w}} & \text { Frontal Flow of Inlet } \\ \mathrm{R}_{\mathrm{f}} & \text { Ratio } \\ \mathrm{t} & \text { time } \\ \mathrm{T} & \text { Total Spread of Water in Gutter } \\ \mathrm{t}_{\mathrm{d}} & \text { Rainfall duration (min) } \\ \mathrm{V} & \text { Velocity } \\ \mathrm{V}_{0} & \text { Splash-over Velocity } \\ \mathrm{w} & \text { Width of Inlet } \\ & \end{array}$




\section{References}

A.O. Akan, R.J. Houghtalen. (2003). Urban hydrology, hydraulics, and stormwater quality: Engineering applications and computer modeling. New Jersey: Wiley.

A.P. Davis, R.G. Traver, W.F. Hunt, R. Lee, R.A. Brown, J.M. Olszewski, (2012). Hydrologic Performance of Bioretention Storm-Water Control Measures, J. Hydrol. Eng. 17 (2012) 604614. doi:10.1061/(ASCE)HE.1943-5584.0000467.

Abida, H., Sabourin J. F. and Ellouze, M., (2007). ANSWAPPS: Model for the analysis of grass swale-perforated pipe systems. Journal of Irrigation and Drainage Engineering, ASCE, (2007) 211-22.

Adams, J.W. (1880). Sewers and drains for populous districts. D. Van Nostrand, New York, NY.

Aquafor Beech Ltd. (1993). Wet Weather Discharges to the Metropolitan Toronto Waterfront, prepared for the Metropolitan Toronto and Region Remedial Action Plan.

Bedient, Philip B., Huber, Wayne C., Vieux, Baxter E. (2012). Hydrology and Floodplain Analysis: Fifth Edition. Harlow: Pearson.

Bendahali, Sogol. (2015). Hydraulic Analysis of Underground Bioretention Systems. MSc. Thesis, Ryerson University.

Brown, R. (2009). Designing Bioretention with an Internal Water Storage (IWS) Layer. http://www.bae.ncsu.edu/stormwater/PublicationFiles/IWS.BRC.2009.pdf.

Bui, T. (2003). A review of stormwater and urban stream management practices in Ontario. In: Proceedings, Environmental and Water Resources. Protection and Restoration of Urban and Rural Streams. Philadelphia, Pennsylvania, (2003) Pp. 61-72.

Burian, SJ and Edwards FG., (2002). Historical Perspectives of Urban Drainage, (2012), Ninth International Conference on Urban Drainage (9ICUD), doi:10.1061/40644(2002)284

C. Hinman. (2009)., Bioretention Soil Mix Review and Recommendation for Western Washington, Washington DC.

Cain, L.P. (1972). "Raising and watering a city: Ellis Sylvester Chesbrough and Chicago's first sanitation system," Technology and Culture 13(1972): 353-372. 
Center for Watershed Protection. (2000). Better Site Design, Ellicott City, MD.

Chanel, Paul Guy. (2008). An Evaluation of Computational Fluid Dynamics for Spillway Modeling. MASc. Thesis, University of Manitoba.

Chris Denich, Aquafor Beech Ltd. and John Antosek, Ontario Ministry of the Environment and Climate Change (MOECC). (2018). Addressing Stormwater in Ontario using Green Infrastructure: The New Ministry of the Environment and Climate Change Low Impact Development Stormwater Management Manual. (TRIECA).

City of Toronto. (2014, March). Sewer and Watermain Design Criteria Manual.

City of Toronto. (2006, November). Wet Weather Flow Management Guidelines.

City of Toronto. (2014). InfoWorks CS Basement Flooding Model Studies Guideline Version 1.02 .

Clar, M., Laramore, E. and Ryan, H. (1993). Design Manual for Use of Bioretention in Stormwater Management, Prepared by Engineering Technologies Associates, Inc. (ETA) and Biohabitats, Inc., prepared for the Department of Environmental Resources, Prince George's County, MD.

Coffman, Larry. (2000). Low-Impact Development Design Strategies, An Integrated Design Approach. EPA 841-B-00-003. Prince George's County, Maryland. Department of Environmental Resources, Programs and Planning Division.

Comsol .(2017, February). What Are the Navier-Stokes Equations? retrieved online from: https://www.comsol.com/multiphysics/navier-stokes-equations

Credit Valley Conservation (CVC); Toronto and Region Conservation (TRCA). (2010). Low Impact Development Stormwater Management Planning and Design Guide, Version 1.0.

CWP. (2000). Better Site Design. Center for Watershed Protection. Ellicott City, MD.

David B. Thompson. (2006). Civil Engineering Department Texas Tech University, The Rational Method. 
Davis, A; Hunt, W; Traver, R; and Clar, M. (2009). Bioretention Technology: Overview of Current Practice and Future Needs. DOI: 10.1061/(ASCE)0733-9372(2009)135:3(109).

Davis, Allen P.; Shokouhian, Mohammad; Sharma, Himanshu; Minami, Christie; Winogradoff, Derek. (2003). Water Quality Improvement through Bioretention: Lead, Copper, and Zinc Removal. Water Environment Research, Volume 75, Number 1, (2003,January/February), pp. 73-82(10), DOI: https://doi.org/10.2175/106143003X140854.

Davis, P. (2008). Field Performance of Bioretention: Hydrology Impacts. 10.1061/(ASCE)1084-0699(2008)13:2(90).

Denise Chow. (2013). Why Toronto Was Drenched by Record Rainfall, available online.

Dietz, M. E. (2007). Low Impact Development Practices: A Review of Current Research and Recommendations for Future Directions. Water Air Soil Pollut (2007) 186: 351. https://doi.org/10.1007/s11270-007-9484-z.

Dubyk, N. (1994). Stormwater quality management: suitability of the Etobicoke exfiltration for urban areas. MSc. Thesis, Ryerson University.

Environmental Planning group. (2011). Low Impact Development Best Management Practices Design Guide, City of Edmonton.

EUWFD (European Union). (2001). Directive 2000/60/EC of the European Parliament and of the council of 23 October 2000: establishing a framework for community action in the field of water policy. Official Journal of the European Communities, 327, 1-72.

Fletcher TD, Shuster W, Hunt WF, et al. (2015). SUDS, LID, BMPs, WSUD and more - The evolution and application of terminology surrounding urban drainage. Urban Water J. (2015). 12(7):525-542. doi:10.1080/1573062X.2014.916314.

Government of South Australia Adelaide. (2009). Water Sensitive Urban Design -Technical Manual.

Graham, P., Maclean, L., Medina, D., Patwardhan, A., and Vasarhelyi, G. (2004). "The Role of Water Balance Modeling in the Transition to Low Impact Development." Water Quality Research Journal of Canada. (2004). 39(4): 331-342. 
H Haris, M F Chow, F Usman, L M Sidek, Z A Roseli and M D Norlida. (2016). Urban Stormwater Management Model and Tools for Designing Stormwater Management of Green Infrastructure Practices, IOP Conference Series: Earth and Environmental Science, Volume 32 , conference 1 .

H. Abida, J.F. Sabourin, M. Ellouze. (2007). ANSWAPPS: Model for the Analysis of Grass Swale-Perforated Pipe Systems, J. Irrig. Drain. Eng. 133 (2007) 211-221. doi:10.1061/(ASCE)0733-9437(2007)133:3(211).

Heasom, W., Traver, R. G., and Walker, A. (2006). "Hydrologic Modeling of a Bioinfiltration Best Management Practice." Journal of the American Water Resource Association. (2006). 42(5): 1329-1347.

Hodge, A.T. (1992). Roman aqueducts \& water supply. Gerald Duckworth \& Co. Ltd., London.

Hollis, G. E. (1977). Water yield changes after the urbanization of the Canon's Brook catchment, Harlow, England. Hydrological Sciences Bulletin. (1977). 22, 61-75.

Holman-Dodds, J. K., Bradley, A. A., \& Potter, K. W. (2003). Evaluation of Hydrologic Benefits of Infiltration Based Urban Stormwater Management. Journal of the American Water Resources Association. (2003). 205-215.

Horner, R. R., Booth, D. B., Azous, A., and May, C. W. (1997). "Watershed Determinants of Ecosystem Functioning." Effects of Watershed Development and Management on Aquatic Ecosystem. ED. C. Roessner. American Society of Civil Engineers, New York: (1997). 251274.

Huber, W., (2012). The History and Evolution of the EPA SWMM. Engineering Conferences International ECI Digital Archives Fifty Years of Watershed Modeling - Past, Present and Future. (2012).

Hunt, W. F., Jarrett, A. R., Smith, J. T, and Sharkey, L. J. (2006). " Evaluating Bioretention Hydrology and Nutrient Removal at Three Field Sites in North Carolina." Journal of Irrigation and Drainage Engineering:10.1061/(ASCE)0733-9437(2006)132:6(600). 
Ice, G. (2004). History of Innovative Best Management Practice Development and its Role in Addressing Water Quality Limited Waterbodies, 10.1061/(ASCE)07339372(2004)130:6(684).

ICF Marbek. (2012). Low Impact Development Discussion Paper. Toronto: Credit Valley Conservation.

James, W. (2018). Revisionist urban drainage modeling history, ICWMM (2018).

Jennings, D. B., \& Jarnagin, S. T. (2002). Changes in anthropogenic impervious surfaces, precipitation and daily streamflow discharge: A historical perspective in a mid-Atlantic subwatershed. Landscape Ecology. (2002). 17, 471-489.

K. Bratieres, T.D. Fletcher, A. Deletic, L. Alcazar, S. Le Coustumer, (2008). Removal of nutrients, heavy metals and pathogens by stormwater biofilters.

Keykhosravi.S, Khan. Usman, Jadidi. A, (2018), A Comprehensive Review of Low Impact Development Models for Research, Conceptual, Preliminary and Detailed Design Applications, Water. (2018). 10(11), 1541; doi:10.3390/w10111541

K.M. Debusk, N.R. Bouchard, M.S. Webb, W.F. Hunt, (2011). Watershed Retrofit and Management Evaluation for Urban Stormwater Management, 12nd Int. Conf. Urban Drain. (2011) 11-16.

Kirby, R.S. and Laurson, P.G. (1932). The early years of modern civil engineering. Yale University Press, New Haven, CT, 227-239.

Kirby, R.S., Withington, S., Darling, A.B., and Kilgour, F.G. (1956). Engineering in history. McGraw-Hill Book Company, Inc., New York, NY.

Kuichling, E. (1889). The relation between the rainfall and the discharge of sewers in populous districts. Transactions of the American Society of Civil Engineers. (1889). 20, 1-60.

Lawson, S. O. (2010). A planning framework for low impact development (LID) in stormwater management - an Ontario perspective. MASc. Thesis, Ryerson University.

Leopold, L. B. (1968). Hydrology for urban land planning — a guidebook on the hydrologic effects of urban land use. Geological Survey Circular. (1968). 554. 
Li, J., (2008). Stormwater performance evaluation of sustainable sidewalk in the city of Toronto. A proposal submitted to Toronto water, city of Toronto.

Li, J, Joksimovic, D. and Chen, L. (2018), Stormwater Performance Evaluation of Soil Cells report.

Linsley, R K et al. (1958). Hydrology for Engineers. New York: McGraw-Hill.

Liu, Haiyue. (2016). Long-Term Performance Modelling of Etobicoke Exfiltration System. MASc. Thesis, Ryerson University.

Lucas, W. C., (2005). Green Technology: The Delaware Urban Runoff Management Approach: Standards, Specifications, and Details for Green Technology BMPs to Minimize Stormwater Impacts from Land Development, prepared for Delaware Department of Natural Resources and Environmental Control, prepared by Integrated Land Management, Inc. (2005, June).

MacMillan, G \& Toronto Region Conservation (TRCA). (2014), Evolution of Storm Water Management in Ontario. Presentation.

Makepeace, D. K., Smith, D. W., \& Stanley, S. J. (1995). Urban stormwater quality: Summary of contaminant data. Critical Reviews in Environmental Science and Technology. (1995). 25(2), 93-139.

Mallin, M.A., J.M. Burkholder \& M.J. Sullivan. (1992). Benthic microalgal contributions to coastal fishery yield. Trans. Am. Fish. Sot. (1992). Vol. 121, pp. 691-695.

Mayer, T., Marsalek, J., \& Reyes, E. D. (1996). Nutrients and Metal Contaminants Status of Urban Stormwater Ponds. Journal of lake and Reservoir Management Volume 12. (1996) Issue 3.

McCutcheon, M., \& Wride, D. (2013). Shades of Green: Using SWMM LID Controls to Simulate Green Infrastructure. Pragmatic Modeling of Urban Water Systems, Monograph 21.

Ministry of Environment and Climate Change. (2015, February). Interpretation Bulletin Ontario Ministry of Environment and Climate Change Expectations Re Stormwater Management.

Ministry of Environment and Energy (MOE) and Ministry of Natural Resources, (1993), Subwatershed Planning. 
Ministry of Natural Resources (MNR), Ministry of Environment, Ministry of Municipal Affairs and Transportation \& Communications, Association of Conservation Authorities of Ontario, Municipal Engineers Association and Urban Development Institute, Ontario. (1987). Guidelines on erosion and sediment control for urban construction sites. PIBS 490e. Toronto, Ontario, Queen's Printer for Ontario.

Ministry of Transportation Ontario (MTO). (1997). Drainage Management Manual.

Morse, C.C., A.D. Huryn, C. Cronan. (2003). Impervious Surface Area as a Predictor of the Effects of Urbanization on Stream Insect Communities in Maine, U.S.A. Environmental Monitoring and Assessment. (2003). 89: 95-127.

Morzaria-Luna, H. N., Schaepe, K. S., Cutforth, L. B, and Veltman, R. L. (2004). "Implementation of Bioretention System: A Wisconsin Case Study." Journal of the American Water Resource Association. (2004). 40(4): 1053-1061.

O'Driscoll, M., et al. (2010). Urbanization effects on watershed hydrology and in-stream processes in the southern United States. Water. (2010). 2 (3), 605-648. doi:10.3390/w2030605 Ontario Ministry of Environment (MOE). (2003). Stormwater Management Planning and Design Manual.

P.G. County. (2009). Bioretention Design Specifications and Criteria.

Patrick Cheung, Rod Anderton, (2017), The Queensway Sustainable Sidewalk Pilot Project, TRIECA Conference. A presentation.

Paul, M.J. and Meyer, J.L. (2001). Streams in the urban landscape. Annual Review of Ecology and Systematics. (2001). 32, 333-365. doi: 10.1146/annurev.ecolsys.32.081501.114040

Porcella, D.B., D.L. Sorenson. (1980). Characteristics of Nonpoint Source Urban Runoff and its Effect on Stream Ecosystems. EPA 600-3-80-032.

Prince George's County. (1999). Low-impact development design strategies: An integrated design approach. Prince George's County, MD Department of Environmental Resources.

Prince George's County. (2001). The bioretention manual, Programs \& Planning Division, Dept. of Environmental Resources, Prince George's County, Md.

Prince George's County. (2007). Bioretention Design Specifications and Criteria. 
Prince George's County Government. (1999). Low-impact development design strategies: An $\begin{array}{llll}\text { integrated } & \text { design } & \text { approach. } & \text { Retrieved }\end{array}$ http://www.lowimpactdevelopment.org/pubs/LID_National_Manual.pdf

Rain Community Solutions. (2015). The story of stormwater, available online.

Randall, M. (2011), Bioretention Gardens for the Removal of Nitrogen and Phosphorous from Urban Runoff. MASc. Thesis, Guelph University.

Reid, D. (1991). Paris sewers and sewermen. Harvard University Press, Cambridge, MA.

Riley, M. (2008). The Effects of Urbanization on Water Quality: A Biological Assessment of Three Bay Area Watersheds using Benthic Macroinvertebrates as Biological Indicators. Water Quality and Urbanization.

Roads and Transportation Association of Canada, (1982). Drainage Manual.

Robert M Roseen, Thomas P Ballestero, James J Houle, Pedro Avellaneda, Joshua Briggs, George Fowler, Robert Wildey. (2009). Seasonal performance variations for storm-water management systems in cold climate conditions. Journal of Environmental Engineering. (2009). 128-137.

Rossman, L. A. (2008). Stormwater Management model User's Manual Version 5.0. Water Supply and Water Resources Division National Risk Managment Reaearch Laboratory, Cincinnati,ON.

S. Paquette, (2012). Modelling of a Bioretention Cell Soil Moisture Regime in Southern Ontario, master's thesis, Guelph University.

S.A. Trowsdale, R. Simcock. (2011). Urban stormwater treatment using bioretention, J. Hydrol. (2011). 397 167-174.

Sansalone, J. and Z. Teng. (2004). "In Situ Partial Exfiltration of Rainfall Runoff.1. Quality and Quantity Attenuation." Journal of Environmental Engineering. (2004). 130(9): 990-1007.

Schreier, Hans. (2015). Water Issues in International Development, UBC.

Schueler .(1995). The Importance of Imperviousness, Watershed Protection Techniques. (1995). 1(3): 100-111. 
Scott J. McGrane (2016) Impacts of urbanisation on hydrological and water quality dynamics, and urban water management: a review, Hydrological Sciences Journal. (2016). 61:13, 22952311, doi: 10.1080/02626667.2015.1128084.

Shafique, M. (2016). A review of the bioretention system for sustainable storm water management in urban areas. 10.1515/rmzmag-(2016)-0020.

Ternier, S. (2012). Review of Stormwater Management in Ontario And a Case Study on the Etobicoke Exfiltration System. MASc. Thesis, Ryerson University.

Tetra Tech, Inc. (2001). "National management measures to control nonpoint source pollution from forestry-February draft.'” Rep. No. EPA 841-D-01-002, U.S. Environmental Protection Agency Office of Water, Washington, D.C.

The Municipal Infrastructure Group Ltd.; Schollen \& Company Inc. (2011). Stormwater Management Feasibility Study.

The Municipal Infrastructure Group Ltd.; Schollen \& Company Inc. (2011). Stormwater Management Feasibility Study. Toronto,Ontario.

Todd, David, K. (1959). Groundwater hydrology. New York: Wiley.

TORONTO PIONEERS UNDERGROUND BIORETENTION available online: wWw.deeproot.com/n.d.

Toronto Region Conservation (TRCA). (2010), STORMWATER MANAGEMENT AND STREAMFLOW, Etobicoke and Mimico Creeks Watersheds Technical Update Report.

TRCA (Toronto and Region Conservation). (2012). Stormwater Management Criteria. Retrieved from http://www.trca.on.ca/the-living-city/water-flood-management/storm-watermanagement.dot

Toronto Region Conservation (TRCA). (2018), The Queensway Sustainable Sidewalk Pilot Project, Sustainable Technologies Evaluation Program (STEP).

U.S. Department of Agriculture (USDA) Forest Service. (1980). "An approach to water resources evaluation on non-point silvicultural sources (a procedural handbook).' Rep. No. EPA-600/8-80-012, U.S. Environmental Protection Agency Environmental Research Laboratory, Athens, Ga. 
Uddin, Zulhash. (2012). Hydraulic Design Model of Underground Bioretention System: A Source Control Measure for Wet Weather Urban Stormwater Management, MASc. Thesis, Ryerson University.

United States Environmental Protection Agency (US EPA) \& Office of Water. (1993). Guidance Manual for Developing Best Management practices (BMP).

United States Environmental Protection Agency (US EPA). (1999). Preliminary Data Summary of Urban Stormwater Best Management Practices. Office of Water.

United States Environmental Protection Agency (USEPA). (2012, March). Urban Runoff: Low Impact Development. Retrieved from URL: https://www.epa.gov/nps/urban-runoff-lowimpact-development

United States Environmental Protection Agency. (2007). Reducing Stormwater Costs through Low Impact Development (LID) Strategies and Practices. Nonpoint Source Control Branch, Washington DC.

United States Environmental Protection Agency-Low Impact Development Center. (2000). Low Impact Development (LID), A Literature Review. EPA-841-B-00-005

US Department of Transportation Federal Highway Administration (USFHWA). (2013). Hydraulic Engineering Circular No. 22 (HEC-22) Urban Drainage Design Manual.

US EPA. (United States Environmental Protection Agency) (1983). Results of the nationwide urban runoff program. United States Environmental Protection Agency, NTIS PB84-185552.

US EPA (United States Environmental Protection Agency) (2002). National water quality inventory, 2000 report. United States Environmental Protection Agency, EPA-841-R-02-001.

US EPA (United States Environmental Protection Agency). (2001). Ambient water quality criteria recommendations: information supporting the development of state and tribal nutrient criteria for rivers and streams in nutrient ecoregion II, EPA 822-B-00-007. Cincinnati, OH: Office of Water Publication, 1-107.

Usta, Eray. (2014). Numerical investigation of hydraulic characteristics of Laleli dam spillway and comparison with physical model study. MSc. Thesis, Middle East Technical University. 
Waananen, A.O. (1969). Effects of watershed changes on streamflow. In W. L. Moore, \& C. W. Morgan (Eds.), Urban effects on water yield. (1969).(pp. 169-182). Austin and London: University of Texas Press.

Walker, D. (1988). Great engineers: the art of British engineers 1837-1987. St. Martin's Press, New York.

Walsh, C.J., et al., (2005). The urban stream syndrome: current knowledge and the search for a cure. Journal of the North American Benthological Society. (2005). 24 (3), 706-723. doi:10.1899/0887-3593(2005)024\[0706: TUSSCK\]2.0.CO;2

Water Canada. (2009, December 21). Sustainable Stormwater Management. Retrieved from https://www.watercanada.net/feature/sustainable-stormwater-management/

FAO (Food and Agriculture Organization) (1991). Water harvesting, A Manual for the Design and Construction of Water Harvesting Schemes for Plant Production.

Watt, W.D., Waters, D. and McLean R. (2003). Climate variability and urban stormwater infrastructure in Canada: context and case studies. Toronto-Niagara Region Study Report and Working Paper Series, Report (2003)-1. Meteorological Service of Canada, Waterloo, Ontario. Wenger, S.J., et al., (2009). Twenty-six key research questions in urban stream ecology: an assessment of the state of the science. Journal of the North American Benthological Society. (2009). 28, 1080-1098. doi:10.1899/08-186.1.

X. Chen (2010) Effectiveness of a Bioretention Cell Treating Stormwater Runoff in Northeastern Kansas BY. MSc., Thesis University of Kansas.

Zhang, W. \& Huang (2015). Soil erosion evaluation in a rapidly urbanizing city (Shenzhen, China) and implementation of spatial land-use optimization, B. Environ Sci Pollut Res (2015) 22: 4475. https://doi.org/10.1007/s11356-014-3454-y

Zheng, Z. (2013). Development of a stormwater Low Impact Development (LID) planning tool. MASc. Thesis. Ryerson University. 